\title{
Recommended Performance-Based Criteria for the Design of Manufactured Home Foundation Systems to Resist Wind and Seismic Loads
}

Richard D. Marshall

National Institute of Standards and Technology

Felix Y. Yokel

Consulting Engineer

Bethesda, Maryland

\section{August 1995}

Building and Fire Research Laboratory

National Institute of Standards and Technology

Gaithersburg, MD 20899

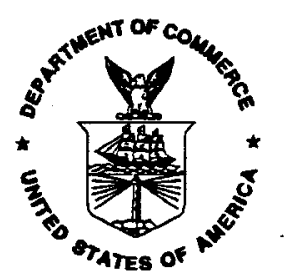

U.S. Department of Commerce

Ronald H. Brown, Secretary

Technology Administration

Mary L. Good, Under Secretary for Technology

National Institute of Standards and Technology

Arati A. Prabhakar, Director
Prepared for:

Department of Housing and Urban Development

Washington, DC 20410 


\begin{abstract}
This report addresses the issue of tornadoes as a basis for the design of manufactured homes and compares base shears due to wind loading with base shears due to earthquake excitation for various wind and seismic zones. Only for annual exceedance probabilities less than about 2.5 x $10^{-4}$ will tornadic wind speeds govern the design for wind loading. In view of the accepted probabilities of attaining or exceeding design limit states for ordinary buildings, it is concluded that tornadoes should not be a part of the wind load design criteria for manufactured homes. Also, it is concluded that transverse base shear due to wind loading will always exceed the base shear due to earthquake loading, regardless of the wind or seismic zone in which the manufactured home is sited. In the longitudinal direction the ranges of base shear for wind and earthquake are approximately equal. These comparisons are based on the assumption that the structural system is properly detailed to resist earthquake forces and is capable of accommodating inelastic deformations several times greater than the deformation at first yield. In view of the uncertainty regarding the dynamic properties of manufactured homes and their support systems, a simplified equation for the determination of seismic base shear is proposed. Traditional anchor/tie/pier systems and current installation practice do not provide adequate windstorm protection for manufactured homes. Even with preloading, the effectiveness of traditional shallow, helix-plate soil anchors is limited to basic wind speeds of approximately 44.7 $\mathrm{m} / \mathrm{s}(100 \mathrm{mph})$. However, there are several alternative anchoring and support systems on the market or under development that can provide the required resistance to wind and earthquake loads. Finally, a set of performance-based criteria for anchoring manufactured homes against wind and earthquake loads is proposed.
\end{abstract}

Keywords: building technology; codes and standards; earthquake engineering; foundations; manufactured homes; mobile homes; soil anchors; structural engineering; wind engineering; wind loads; windstorm protection. 


\section{DISCLAIMER}

Certain trade names and company products are mentioned in the text or are identified in an illustration to adequately describe hardware or components used for supporting or anchoring manufactured homes. In no case does such identification imply recommendation or endorsement by the National Institute of Standards and Technology, nor does it imply that the products are necessarily the best available for the purpose. 


\section{TABLE OF CONTENTS}

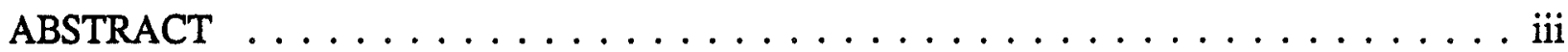

DISCLAIMER $\ldots \ldots \ldots \ldots \ldots \ldots \ldots \ldots \ldots \ldots \ldots \ldots \ldots \ldots \ldots \ldots \ldots \ldots$

LIST OF TABLES $\ldots \ldots \ldots \ldots \ldots \ldots \ldots \ldots \ldots \ldots \ldots \ldots \ldots \ldots \ldots$

LIST OF FIGURES $\ldots \ldots \ldots \ldots \ldots \ldots \ldots \ldots \ldots \ldots \ldots \ldots$ viii

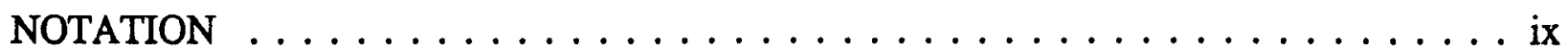

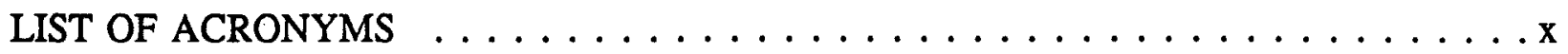

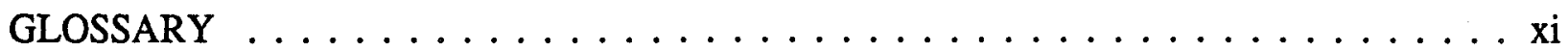

EXECUTIVE SUMMARY $\ldots \ldots \ldots \ldots \ldots \ldots \ldots \ldots \ldots \ldots \ldots \ldots \ldots \ldots$ xiii

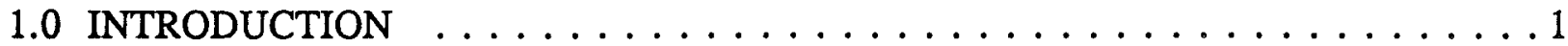

2.0 DESIGN WIND SPEEDS FOR MANUFACTURED HOMES $\ldots \ldots \ldots \ldots \ldots$

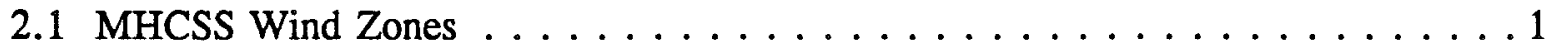

2.2 Tornadoes as a Design Consideration $\ldots \ldots \ldots \ldots \ldots$

3.0 WIND FORCES ACTING ON SUPPORT AND ANCHORING SYSTEMS $\ldots \ldots 7$

3.1 Nominal Wind Loads $\ldots \ldots \ldots \ldots \ldots \ldots \ldots$

3.2 Diagonal Frame-Tie and Pier Reactions for Single-Wide Homes

Due to Wind plus Dead Load . . . . . . . . . . . . . . . . . . 10

3.3 Main-Frame Reactions for Single-Wide Homes

Due to Wind plus Dead Load . . . . . . . . . . . . . . . . 13

4.0 ANCHORAGE REQUIREMENTS FOR EARTHQUAKE LOADS $\ldots \ldots \ldots \ldots$

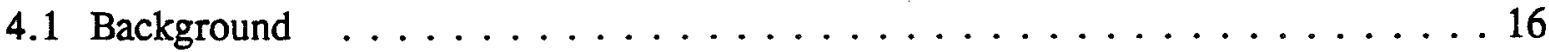

4.2 Requirements of the Uniform Building Code $\ldots \ldots \ldots \ldots$

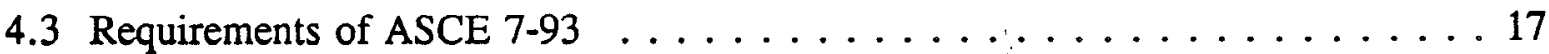


4.4 A Simplified Base Shear Equation $\ldots \ldots \ldots \ldots \ldots \ldots$

4.5 Seismic Dead Load and Overturning Moment at the Foundation Level . . . . 19

4.6 Comparison of Base Shear Due to Earthquake and to Wind Loads . . . . . . 21

5.0 OVERVIEW OF GENERIC SUPPORT AND ANCHORING SYSTEMS . . . . 25

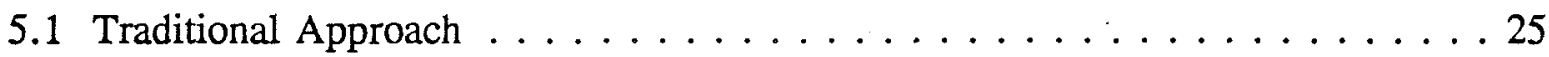

5.2 Arrowhead or Swivel Soil Anchors $\ldots \ldots \ldots \ldots \ldots \ldots$

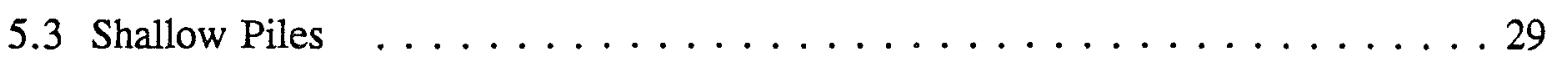

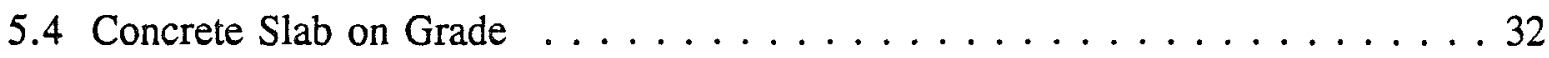

5.5 Portable Precast Concrete Piers $\ldots \ldots \ldots \ldots \ldots \ldots \ldots \ldots$

5.6 Permanent Foundations $\ldots \ldots \ldots \ldots \ldots \ldots \ldots \ldots \ldots \ldots \ldots \ldots \ldots$

6.0 PERFORMANCE-BASED CRITERIA FOR MANUFACTURED HOME SUPPORT AND ANCHORING SYSTEMS $\ldots \ldots \ldots \ldots \ldots \ldots$

6.1 Allowable Soil Bearing Pressures $\ldots \ldots \ldots \ldots \ldots \ldots$

6.2 Horizontal Load Effects $\ldots \ldots \ldots \ldots \ldots \ldots$

6.3 Allowable Horizontal Displacements . . . . . . . . . . . . . . 38

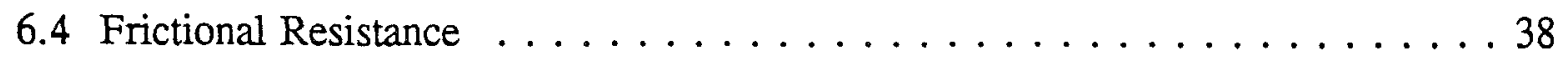

6.5 Durability of Foundation Elements $\ldots \ldots \ldots \ldots \ldots \ldots$

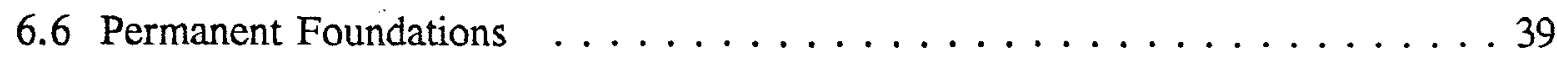

6.7 Earthquake Effects . . . . . . . . . . . . . . . . . 39

6.7.1 Earthquake Resistant Foundation Support Systems . . . . . . . . . . 39

6.7.2 Earthquake Resistant Secondary Support Systems . . . . . . . . . . . . . 39

6.8 Commentary $\ldots \ldots \ldots \ldots \ldots \ldots \ldots \ldots \ldots \ldots \ldots \ldots \ldots \ldots \ldots \ldots$

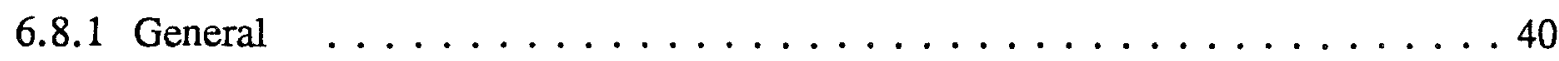


C6.1 Allowable Soil Bearing Pressures $\ldots \ldots \ldots \ldots$

C6.2 Horizontal Load Effects . . . . . . . . . . . . . . . . . . 40

C6.3 Allowable Horizontal Displacements . . . . . . . . . . . . . . . . 40

C6.4 Frictional Resistance . . . . . . . . . . . . . . . . . . 40

C6.5 Durability of Foundation Elements ................. 41

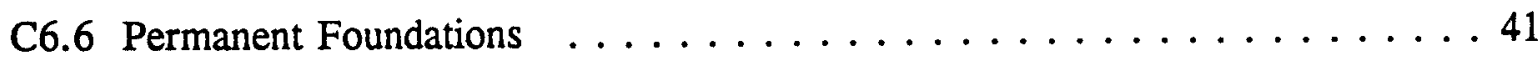

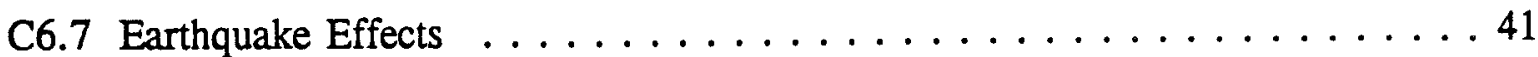

C6.7.1 Earthquake Resistant Foundation Support Systems . . . . . . . . . 41

C6.7.2 Earthquake Resistant Secondary Support Systems . . . . . . . . . . . 41

7.0 MAJOR FINDINGS AND RECOMMENDATIONS $\ldots \ldots \ldots \ldots$

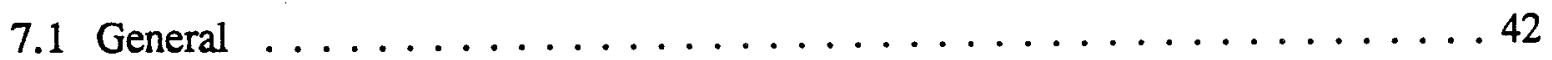

7.2 Major Findings . . . . . . . . . . . . . . . . . 42

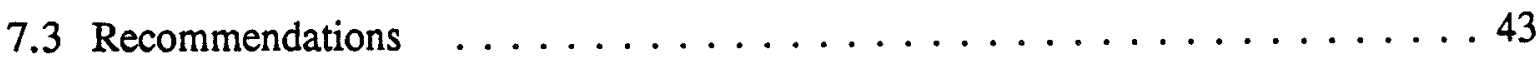

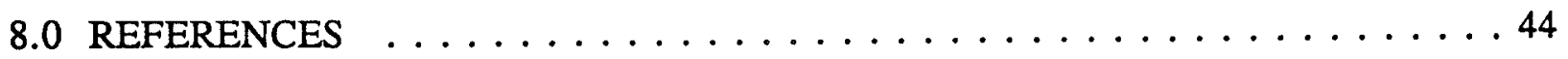

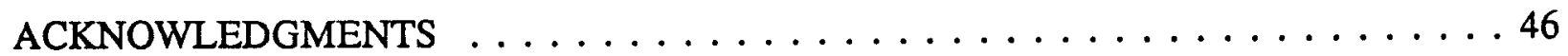

APPENDIX A - Sample Load Calculations . . . . . . . . . . . . . . 47

APPENDIX B - Computer Program for Calculating Wind Load Reactions . . . . . . 51

APPENDIX C - Overview of Selected Requirements for Windstorm Protection . . . . 54

\section{LIST OF TABLES}

Table 1. MHCSS-94 Wind Zones and Basic Wind Speeds . . . . . . . . . . . . . 1

Table 2. Regional Tornado Characteristics $\ldots \ldots \ldots \ldots \ldots \ldots$

Table 3. Comparison of Tornado Regions $\ldots \ldots \ldots \ldots \ldots$ 
Table 4. Nominal Wind Loads for Single- and Double-Wide Manufactured Homes . . . 9

Table 5. Zone I Single-Wide Loads for Diagonal Frame-Ties and for Piers . . . . . 11

Table 6. Zone II Single-Wide Loads for Diagonal Frame-Ties and for Piers . . . . . . 12

Table 7. Zone III Single-Wide Loads for Diagonal Frame-Ties and for Piers . . . . 12

Table 8. Zone I Single-Wide Main-Frame Reactions . . . . . . . . . . . . . 14

Table 9. Zone II Single-Wide Main-Frame Reactions $\ldots \ldots \ldots \ldots$

Table 10. Zone III Single-Wide Main-Frame Reactions $\ldots \ldots \ldots \ldots \ldots$

Table 11. Seismic Base Shears for a Single-Wide Manufactured Home . . . . . . . . 21

Table 12. Factored Base Shears Due to Wind Loading . . . . . . . . . 23

Table 13. Event Producing the Largest Longitudinal Base Shear $\ldots . . . . . . .24$

Table 14. Field Test Results for Shallow Piles $\ldots \ldots \ldots \ldots 32$

Table 15. Comparison of Concrete Quantities: Slab on Grade vs. Precast Piers . . . . . 36

\section{LIST OF FIGURES}

Figure 1. Basic wind zone map for manufactured housing $\ldots \ldots \ldots \ldots \ldots$

Figure 2. Tornado wind speeds corresponding to an annual exceedance probability

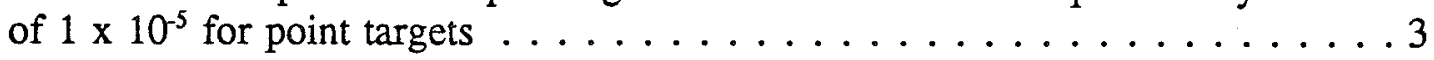

Figure 3. Regional exceedance probabilities for tornado wind speeds and the distribution of extreme wind speeds for Omaha, Nebraska . . . . . . 5

Figure 4. Mean regional tornado wind speed exceedance probabilities

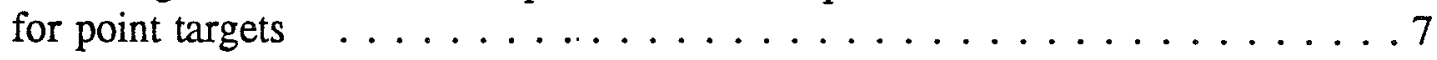

Figure 5. Loads and reactions for traditional diagonal frame-ties and piers $\ldots \ldots \ldots 8$

Figure 6. Reactions in terms of horizontal shear and vertical forces

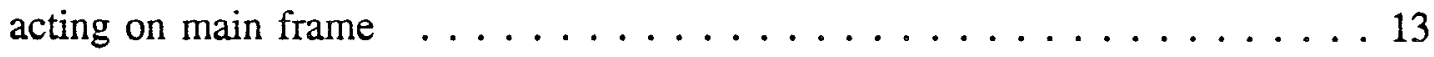

Figure 7. Relationship between fundamental period $\mathrm{T}$ and $\mathrm{C}_{\mathrm{s}}$ or $\mathrm{ZIC} / \mathrm{R}_{\mathrm{w}} \ldots \ldots \ldots 18$ 
Figure 8. Arrowhead or swivel soil anchor $\ldots \ldots \ldots \ldots \ldots \ldots$

Figure 9. Anchoring scheme employing arrowhead anchors $\ldots \ldots \ldots . \ldots . \ldots$

Figure 10. Reactions for a single-wide home in wind Zone III using the anchor arrangement shown in Figure $9 \ldots \ldots . \ldots 28$

Figure 11. Reactions for a single-wide home in wind Zone III using traditional frame-tie and pier arrangement shown in Figure 5 . . . . . . . . . 29

Figure 12 . Shallow pipe pile with telescoping insert $\ldots \ldots \ldots \ldots \ldots$

Figure 13. Concrete Slab on Grade $\ldots \ldots \ldots \ldots$

Figure 14. Portable Precast Concrete Piers $\ldots \ldots \ldots \ldots$. . . . . . . . . 34

\section{NOTATION}

The following symbols are used in this report:

A Area

A Coefficient representing effective peak acceleration

A $\quad$ Area of steel reinforcing per unit width of slab

$A_{v} \quad$ Coefficient representing effective peak velocity-related acceleration

C Numerical coefficient used to determine seismic base shear

$\mathrm{C}_{\mathrm{p}} \quad$ Pressure coefficient

$\mathrm{C}_{\mathrm{s}} \quad$ Seismic design coefficient

$\mathrm{C}_{t} \quad$ Coefficient used to estimate the fundamental period of a structure

$\mathrm{C}_{\mathrm{vx}} \quad$ Vertical distribution factor for appropriate portions of the total seismic base shear

D Dead load

E Earthquake load

$F_{x} \quad$ Lateral earthquake force assigned to level $x$

$\mathrm{G}_{\mathrm{b}} \quad$ Gust response factor

$\mathrm{H}$ Location of action line of resultant horizontal earthquake force above ground level

I Structure importance factor

$\mathrm{K}_{\mathrm{h}} \quad$ Velocity pressure exposure coefficient evaluated at height $\mathrm{h}$

$\mathrm{M}_{\mathrm{W}} \quad$ Overturning moment due to wind loads

$\mathrm{M}_{\mathrm{s}} \quad$ Overturning moment due to earthquake loads

$P_{w} \quad$ Drag load

$P_{R L} \quad$ Uplift load on leeward roof

$\mathbf{P}_{\mathrm{RW}} \quad$ Uplift load on windward roof

$\mathbf{R} \quad$ Response modification coefficient

$\mathbf{R}_{\mathbf{L}} \quad$ Leeward pier reaction 
$\mathrm{R}_{\mathrm{w}} \quad$ Windward pier reaction

$R_{\mathrm{w}} \quad$ Response modification factor that depends on the type of basic structural system

S Site coefficient that accounts for local soil profile characteristics

$\mathrm{T} \quad$ Fundamental period of structure

$T_{D} \quad$ Force in diagonal tie

$\mathrm{T}_{\mathrm{v}} \quad$ Force in vertical tie

$\mathrm{U}_{\mathrm{FM}} \quad$ Fastest-mile wind speed

$\mathrm{U}_{\mathrm{wt}} \quad$ Wind speed associated with ultimate limit state

$\mathrm{U}_{50} \quad$ Wind speed associated with 50-yr mean recurrence interval

$\mathrm{V}$ Base shear

W Wind load, Total seismic dead load

Z Seismic zone factor

a Main-frame spacing

b Width of manufactured home

$f_{y} \quad$ Yield strength

$\mathrm{h} \quad$ Net height (box height) of manufactured home

$h_{n} \quad$ The level which is uppermost in the main portion of a structure

$h_{x} \quad$ Height from base to level $x$

$\mathrm{q}_{\mathrm{b}} \quad$ Velocity pressure at height $\mathrm{h}$

$\alpha \quad$ Angle of plane of roof from horizontal

$\gamma_{\mathrm{D}} \quad$ Dead load factor

$\gamma_{\mathrm{w}} \quad$ Wind load factor

$\theta \quad$ Angle of diagonal tie from horizontal

$\rho \quad$ Mass density

$\phi \quad$ Resistance factor

\section{LIST OF ACRONYMS}

ANS American Nuclear Society

ANSI American National Standards Institute

ASCE American Society of Civil Engineers

ASD Allowable stress design

HUD Department of Housing and Urban Development

LRFD Load and resistance factor design

MHCSS Manufactured Home Construction and Safety Standards

MRI Mean Recurrence Interval 
NCSBCS National Conference of States on Building Codes and Standards

NIST National Institute of Standards and Technology

SPT Standard penetration test

STP Soil test probe

\section{GLOSSARY}

Allowable stress design: a method of proportioning structures such that the computed elastic stress does not exceed a specified limiting stress.

Anchoring system: the combination of ties and soil anchors which provides stability for manufactured homes.

Basic wind speed: fastest-mile wind speed at $10 \mathrm{~m}(33 \mathrm{ft})$ above ground level in flat, open country and having an annual probability of 0.02 of being equaled or exceeded.

Cone of influence: the volume of soil activated during anchor withdrawal, generally assumed to be conical in shape with the surface at 45 degrees to the anchor shaft.

Dead load: load due to structural self-weight and the permanent features of a building.

Diagonal tie: the inclined link between the manufactured home and a soil anchor which resists lateral loads and uplift loads.

Factored load: the product of the nominal load and a load factor.

Fastest-mile speed: the wind speed averaged over the time required for a mile-long volume of air to pass a fixed point.

Importance factor: a factor that accounts for the degree of hazard to human life and damage to property.

Limit states: criteria beyond which a structure or structural element is judged to be no longer useful for its intended function (serviceability limit state) or beyond which it is judged to be unsafe (ultimate limit state).

Live load: the load superimposed on a structure by use and occupancy of the structure.

Load and resistance factor design: a design method which uses load and resistance factors in the design format. 
Load factor: a factor that accounts for unavoidable deviations of the actual load from the nominal value and the uncertainties in the analysis that transforms the load into a load effect.

Main frame: that part of the manufactured home structural system which is normally used to transmit accumulative design loads to the support system.

Main-frame spacing: distance between the primary longitudinal members of the main frame of a manufactured home.

Mean recurrence interval: the number of years, on average, between events of like magnitude or intensity.

Nominal load: load specified by a code or standard; usually defined with reference to some probability of being exceeded.

Pier: that portion of the support system between the footing and the manufactured home, exclusive of caps and shims.

Resistance factor: a factor by which the nominal resistance is multiplied to account for the uncertainties in its determination.

Seismic dead load: the total dead load and applicable portions of other loads as specified for the purpose of calculating earthquake loads.

Service load: the maximum load or combination of loads that a structure or structural component is expected to experience during its design life.

Soil anchor: a device which is either driven or screwed into the ground and to which vertical and/or diagonal ties are attached.

Stabilizer plate: a rectangular steel plate or similar device intended to provide resistance to lateral movement of an anchor shaft.

Structural stability: resistance to being displaced by a force or combination of forces.

Support system: a combination of footings, piers and shims that supports the manufactured home.

Uplift load: wind-induced load acting on a structure in the vertical direction.

Vertical tie: the vertical link between the manufactured home and a soil anchor which resists uplift loads. 


\section{EXECUTIVE SUMMARY}

The Manufactured Home Construction and Safety Standards (MHCSS) were amended on January 14,1994 , resulting in new design wind load requirements for the hurricane-prone coastal regions of the United States and certain other designated areas. The requirements for non-hurricane regions of the United States were not revised, but those requirements are under review by the Department of Housing and Urban Development. The amended rules follow closely the wind load provisions of ASCE 7-93, Minimum Design Loads for Buildings and Other Structures.

In previous studies (Yokel et al. 1982, Longinow et al. 1991, Marshall 1994) it was shown that traditional soil anchor installation practice does not provide the level of windstorm protection suggested by the provisions of the MHCSS or of NCSBCS/ANSI A225.1, Manufactured Home Installations. Among other issues, this report examines manufactured home support and anchoring systems and the degree to which tornadic wind speeds should influence their design. With the analyses presented herein, it is demonstrated that for ordinary buildings and structures, including manufactured homes, the annual probability of failure due to tornadoes is substantially less than that associated with other types of storms. Only for annual exceedance probabilities less than about $2.5 \times 10^{-4}$ will tornadic wind speeds govern the design for wind loading. Therefore, it is concluded that the criteria for the design of manufactured homes and their windstorm protection systems should not include the effects of tornadoes. This conclusion is consistent with the fact that ASCE 7-93 does not address tornadic wind speeds explicitly. Nevertheless, tornadoes constitute a significant hazard to human life and property, and tornado shelters should be an integral part of manufactured home parks.

This report also compares the lateral load requirements due to seismic effects with those due to wind loading. If the minimum design wind speed for manufactured homes is assumed to be 31.3 $\mathrm{m} / \mathrm{s}(70 \mathrm{mph})$, the transverse base shear due to wind loading will always exceed the base shear due to earthquake loading, regardless of the wind or seismic zone in which the manufactured home is sited. However, this comparison is based on the assumption that the structural system is properly detailed to resist earthquake forces and is capable of accommodating inelastic deformations that are several times greater than the deformation at first yield. Structural systems not meeting this requirement may develop substantially higher earthquake forces. In the longitudinal direction the ranges of base shear for wind and for earthquake are approximately equal, and each must be checked to establish the governing event. In view of the fact that there is considerable uncertainty regarding the dynamic properties of manufactured homes and their support systems, a simplified equation for the determination of seismic base shear is proposed.

Preloading of shallow soil anchors can remove much of the uncertainty associated with traditional installation practice, can substantially increase the lateral stiffness of such anchors, and allows one to take advantage of the higher ultimate capacities inherent in vertically installed anchors subjected to inclined loads. However, even with preloading, the traditional shallow soilanchor/tie/pier system is limited to applications where the basic wind speed does not exceed 44.7 $\mathrm{m} / \mathrm{s}$ (100 mph).

xiii 
There are several innovative foundation/anchoring systems available or under development that show considerable promise and can be expected to perform substantially better than the traditional shallow soil-anchor/tie/pier system under either wind or earthquake loading. The continued development of such systems should be encouraged, and an important first step in this direction is the development of performance-based criteria for the design of foundation/anchoring systems.

A set of performance-based criteria for manufactured home foundation/anchoring systems is proposed in this report. Performance-based criteria offer a more uniform and rational approach to the design of windstorm protection and support systems and have the added advantage of not excluding innovative and potentially superior systems. 


\subsection{INTRODUCTION}

On January 14, 1994, the Department of Housing and Urban Development amended the Federal Manufactured Home Construction and Safety Standards (HUD 1994) to bring the wind load requirements into line with contemporary codes and standards. This amendment establishes wind Zones II and III for which the basic wind speeds are 44.7 and $49.2 \mathrm{~m} / \mathrm{s}$ (100 and $110 \mathrm{mph}$ ), respectively. The required design wind loads for these zones are in general agreement with the loads specified by ASCE 7-93, Minimum Design Loads for Buildings and Other Structures. Design wind loads for areas not included in Zones II and III remain unchanged. Note that the wind load provisions of ASCE 7-88 and ASCE 7-93 are identical.

Although the MHCSS-94 amended requirements for wind loading represent a significant improvement, the requirements for providing windstorm protection through adequate tiedown systems are relatively unchanged. A review of such systems and recommendations for improvement have been addressed by Marshall (1994). This report considers the general problem of anchorage and support for manufactured homes, and both wind and seismic effects are addressed. Some innovative anchorage and support systems are reviewed, and recommended performance-based criteria for the design of manufactured home foundations are presented.

\subsection{DESIGN WIND SPEEDS FOR MANUFACTURED HOMES}

\subsection{MHCSS Wind Zones}

The Manufactured Home Construction and Safety Standards (Part 3280) establish three wind speed zones as indicated in Table 1 for the design of manufactured homes to resist wind effects. The MHCSS-94 wind zone designations and zone boundaries are shown in Figure 1.

Table 1. MHCSS-94 Wind Zones and Basic Wind Speeds

\begin{tabular}{|c|c|c|c|}
\hline & Zone Designation & $\begin{array}{l}\text { Fastest- } \\
(\mathrm{m} / \mathrm{s})\end{array}$ & $\begin{array}{l}\text { Vind Speed } \\
\quad(\mathrm{mph})\end{array}$ \\
\hline & Wind Zone I & 29.1 & (65) \\
\hline & Wind Zone II & 44.7 & $(100)$ \\
\hline & Wind Zone III & 49.2 & (110) \\
\hline Note: & \multicolumn{3}{|c|}{$\begin{array}{l}\text { For Zones II and III, the indicated wind speeds are multiplied by a structure } \\
\text { importance factor of } 1.05 \text { when calculating design wind loads. }\end{array}$} \\
\hline
\end{tabular}




\section{Basic Wind Zone Map for Manufactured Housing}

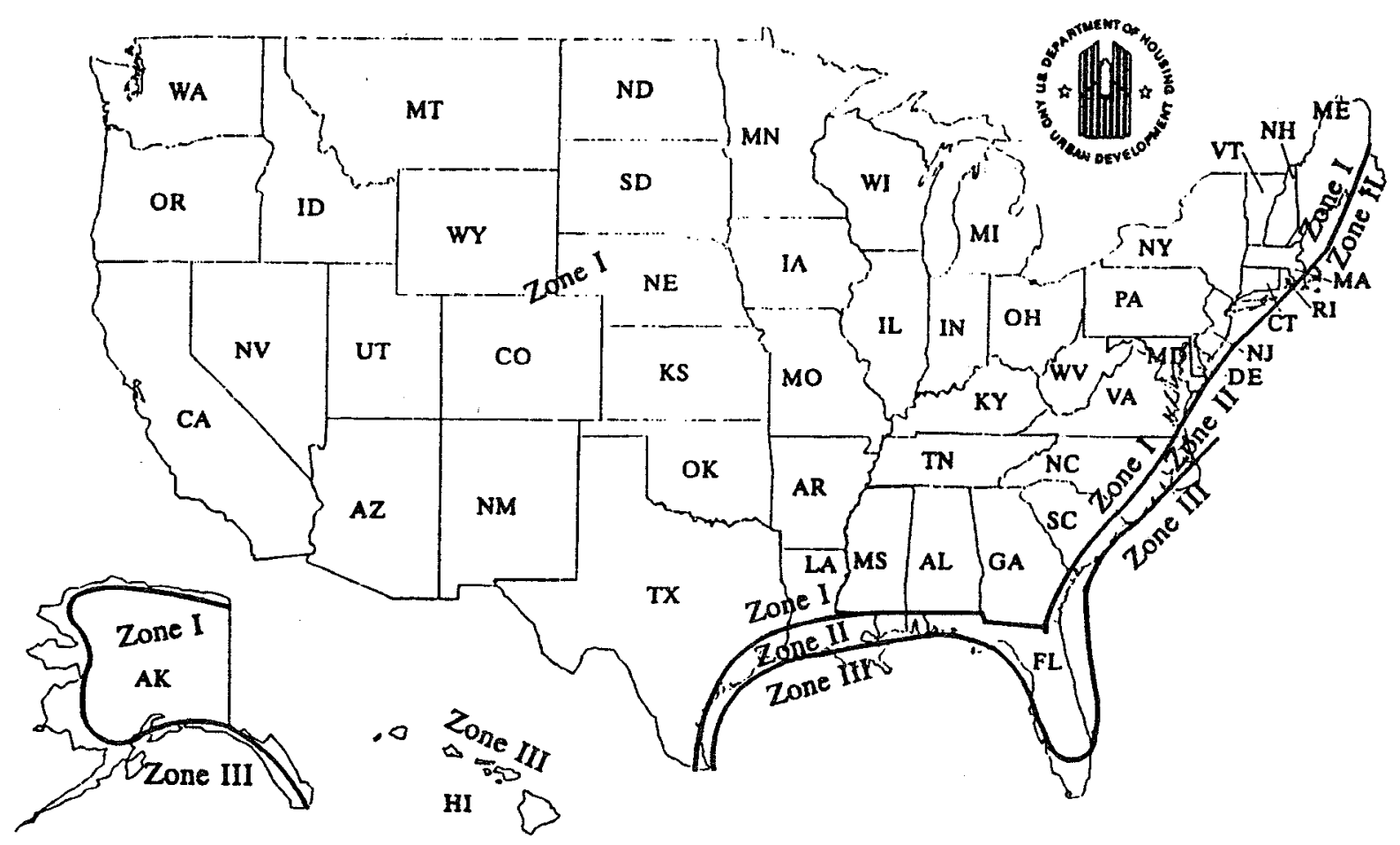

Figure 1. Basic wind zone map for manufactured housing (MHCSS-94).

For wind Zone I, the MHCSS-94 design wind speed of $29.1 \mathrm{~m} / \mathrm{s}(65 \mathrm{mph})$ is inferred from the specified drag and uplift loads as MHCSS-94 does not explicitly state a design wind speed for this zone. For wind Zones II and III, the design speeds correspond to basic wind speeds as

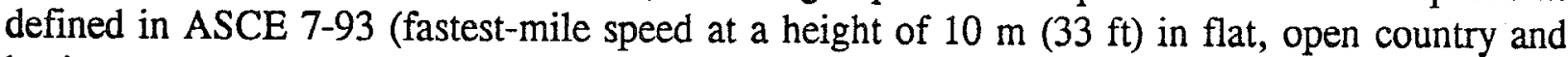
having an annual probability of 0.02 of being equalled or exceeded). Approximately, the boundaries between Zones I and II, and between Zones II and III, correspond respectively to the $90 \mathrm{mph}$ and $100 \mathrm{mph}$ isotachs shown on the ASCE 7-93 map of basic wind speeds. Within Zone I the ASCE 7-93 basic wind speeds range from 31.3 to $40.2 \mathrm{~m} / \mathrm{s}$ (70 to $90 \mathrm{mph}$ ) with special wind regions shown for which higher speeds may be expected because of local topographic features. 


\subsection{Tornadoes as a Design Consideration}

Because much of the wind damage experienced each year in the United States is attributable to tornadoes, it is important to consider to what extent tornadoes should be included in the development of wind load criteria for manufactured homes. Figure 2 is a map showing the regional distribution of tornado wind speeds having an annual probability of $1 \times 10^{-5}$ of being equaled or exceeded at a point target. This map was prepared by Committee ANS 2.3 of the American Nuclear Society in the early 1980s, and the wind speeds are consistent with the speeds used in the tornado classification system developed by Fujita (1971). Presumably, the Fujita scale is based on fastest quarter-mile speeds (speeds averaged over the time required for a volume of air $1 / 4$-mile long to pass a fixed point), although this interpretation is open to some question (NRC 1993).

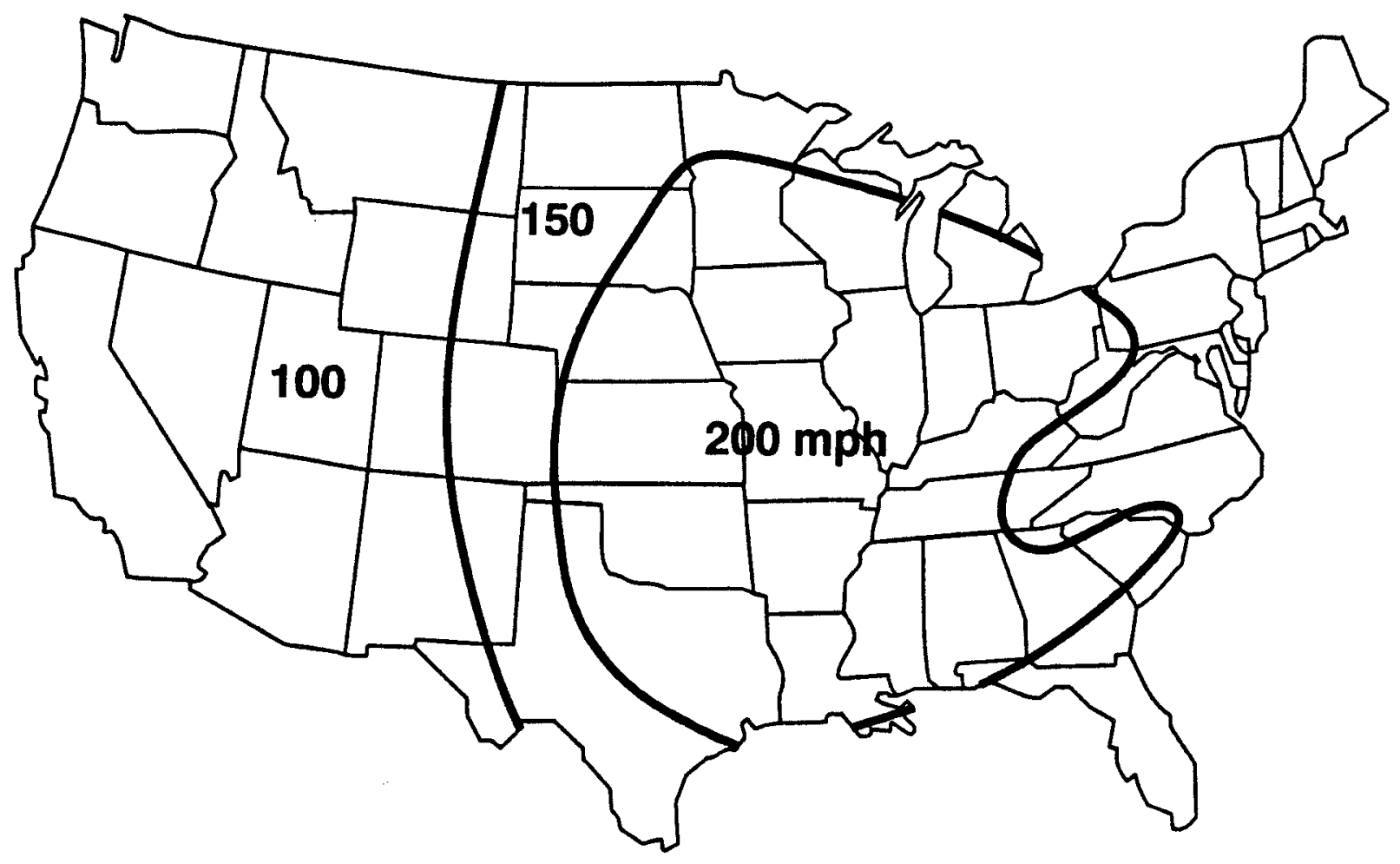

Figure 2. Tornado wind speeds corresponding to an annual exceedance probability of $1 \times 10^{5}$ for point targets (ANSI/ANS 2.3-1983).

The tornado wind speeds for the three regions indicated in Figure 2 and for three annual probabilities of being equaled or exceeded are listed in Table 2. Also listed in Table 2 are equivalent fastest-mile wind speeds and radii of maximum rotational speed. 
Table 2. Regional Tornado Characteristics (ANSI/ANS 2.3-1983)

\begin{tabular}{|c|c|c|c|c|c|c|c|}
\hline \multirow{2}{*}{$\begin{array}{l}\text { Annual } \\
\text { Exceedance } \\
\text { Probability }\end{array}$} & \multirow[t]{2}{*}{$\begin{array}{l}\text { Map } \\
\text { Region }\end{array}$} & \multicolumn{2}{|c|}{$\begin{array}{c}\text { Maximum* } \\
\text { Wind Speed }\end{array}$} & \multicolumn{2}{|c|}{$\begin{array}{l}\text { Equivalent } \\
\text { Fastest-Mile } \\
\text { Wind Speed }\end{array}$} & \multicolumn{2}{|c|}{$\begin{array}{l}\text { Radius of Maximum } \\
\text { Rotational Speed }\end{array}$} \\
\hline & & $(\mathrm{m} / \mathrm{s})$ & $(\mathrm{mph})$ & $(\mathrm{m} / \mathrm{s})$ & (mph) & (m) & (ft) \\
\hline \multirow[t]{3}{*}{$1 \times 10^{-5}$} & 1 & 89.4 & (200) & 82.7 & (185) & 108 & (355) \\
\hline & 2 & 67.1 & (150) & 61.2 & (137) & 82 & (270) \\
\hline & 3 & 44.7 & (100) & 39.8 & (89) & 56 & (185) \\
\hline \multirow[t]{3}{*}{$1 \times 10^{-6}$} & 1 & 116.2 & (260) & 108.2 & (242) & 138 & (453) \\
\hline & 2 & 89.4 & (200) & 82.7 & (185) & 108 & (355) \\
\hline & 3 & 62.6 & (140) & 56.8 & (127) & 77 & (253) \\
\hline \multirow[t]{3}{*}{$1 \times 10^{-7}$} & 1 & 143.0 & (320) & 133.7 & (299) & 165 & (540) \\
\hline & 2 & 111.8 & (250) & 103.7 & (232) & 133 & (435) \\
\hline & 3 & 80.5 & (180) & 74.2 & (166) & 98 & (320) \\
\hline
\end{tabular}

Plotted in Figure 3 are the equivalent fastest-mile tornado wind speeds for the three tornado regions and three annual exceedance probabilities listed in Table 2. Also plotted in Figure 3 is the relationship between fastest-mile wind speed and annual exceedance probability for Omaha, Nebraska, in which tornadoes have been excluded (Simiu et al. 1979). Note that Omaha is located in Region 1 of the map shown in Figure 2. It is seen from Figure 3 that the distribution of annual extremes for Omaha and the distribution of Region 1 tornado wind speeds intersect at a mean recurrence interval of approximately 9,000 years (annual exceedance probability of $1.1 \times 10^{-4}$. For longer mean recurrence intervals tornadoes would dominate wind risk, while for shorter mean recurrence intervals it would be extra-tropical cyclones and thunderstorms. 


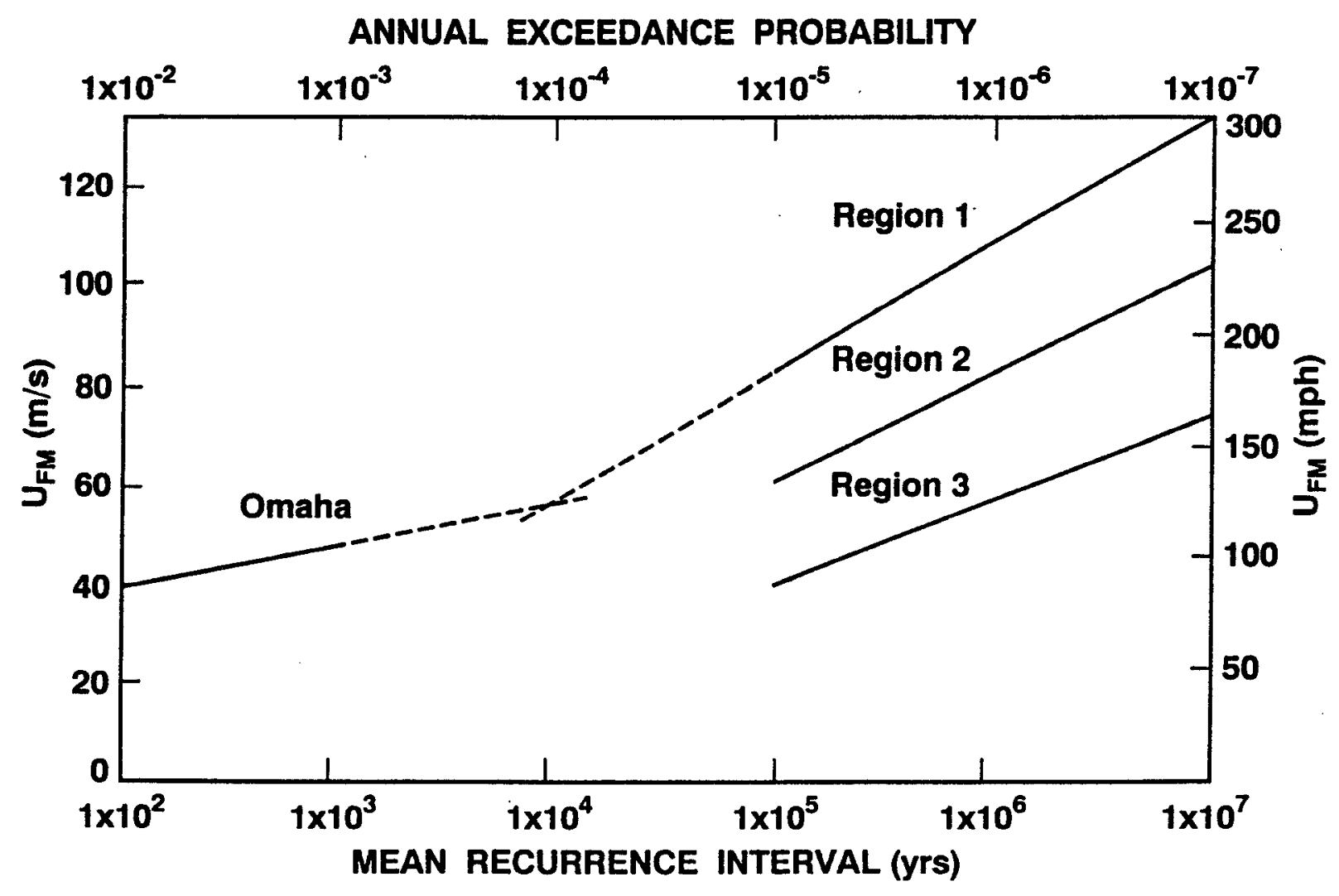

Figure 3. Regional exceedance probabilities for tornado wind speeds and the distribution of extreme speeds for Omaha, Nebraska.

A more rigorous formulation of the tornado risk problem has been developed by Twisdale and Dunn (1983). As with ANSI/ANS 2.3-1983, the continental U.S. is divided into regions (A, $\mathrm{B}, \mathrm{C}$ and $\mathrm{D})$, and exceedance probabilities for point targets are estimated. The regional designations used in ANSI/ANS 2.3-1983 and those used by Twisdale and Dunn are compared in Table 3. 
Table 3. Comparison of Tornado Regions - ANSI/ANS 2.3-1983 vs. Twisdale and Dunn.

ANSI/ANS 2.3-1983

Twisdale and Dunn

Region Designation

Region Designation
1
A \& B
2
C (Includes south Florida)
D (Includes New England)

Equivalent fastest-mile wind speeds are plotted against annual exceedance probabilities in Figure 4 for the four tornado regions defined by Twisdale and Dunn. Again, the exceedance probabilities are for a tornado striking a point target. Also indicated in Figure 4 is the estimated fastest-mile wind speed, $U_{\text {ult }}$, which corresponds to the ultimate (strength) limit state for ordinary buildings and structures designed on the basis of a 50-year MRI wind speed. It is assumed that $\mathrm{U}_{\mathrm{utt}}$ can be defined by the relationship

$$
\mathrm{U}_{\mathrm{ult}}=\left(\mathrm{U}_{50}\right)\left(\gamma_{\mathrm{w}} / \phi\right)^{1 / 2}=1.27 \mathrm{U}_{50}
$$

where $\mathrm{U}_{50}$ is the basic wind speed (50-yr MRI) as defined in ASCE 7-93, $\gamma_{\mathrm{w}}$ is the wind load factor equal to 1.3 , and $\phi$ is the resistance factor, assumed here to be 0.8 (Marshall 1994).

The minimum basic wind speed permitted by ASCE 7-93 for the design of ordinary buildings and structures is $U_{50}=31.3 \mathrm{~m} / \mathrm{s}(70 \mathrm{mph})$, and the corresponding value of $U_{\text {ult }}$ is $39.7 \mathrm{~m} / \mathrm{s}(89$ $\mathrm{mph}$ ). This wind speed intersects the wind speed distribution curves for Regions $\mathrm{A} / \mathrm{B}$ at a mean recurrence interval of about 4,000 years (annual exceedance probability of $2.5 \times 10^{4}$ ). The limit-state wind speeds derived from higher basic wind speeds will intersect the regional tornado wind speed distribution curves at even longer mean recurrence intervals. For the design of ordinary buildings and structures, including manufactured homes, it is generally accepted that the annual probability of attaining an ultimate limit state (structural failure) should be about 1 $x 10^{-3}$ (Gupta and Moss 1993). Therefore, the exclusion of tornado wind speeds from the wind load design criteria for manufactured homes and for other low-rise buildings that need not serve a critical post-disaster function appears to be justified.

In summary, for the level of risk considered acceptable for ordinary buildings, the wind speeds associated with non-tornado events exceed the wind speeds associated with tornadoes. Therefore, it is the non-tornado events that dictate the design wind speeds for manufactured homes. It is interesting to note that although some 1,000 tornado events are recorded in the United States each year, approximately 70 percent of these tornadoes generate maximum wind speeds of less than $50 \mathrm{~m} / \mathrm{s}(112 \mathrm{mph})$ while 90 percent exhibit maximum speeds of less than 70 
$\mathrm{m} / \mathrm{s}$ (157 mph) (NRC 1993). Nevertheless, tornadoes constitute a significant hazard to human life, and tornado shelters should be an integral part of manufactured home parks.

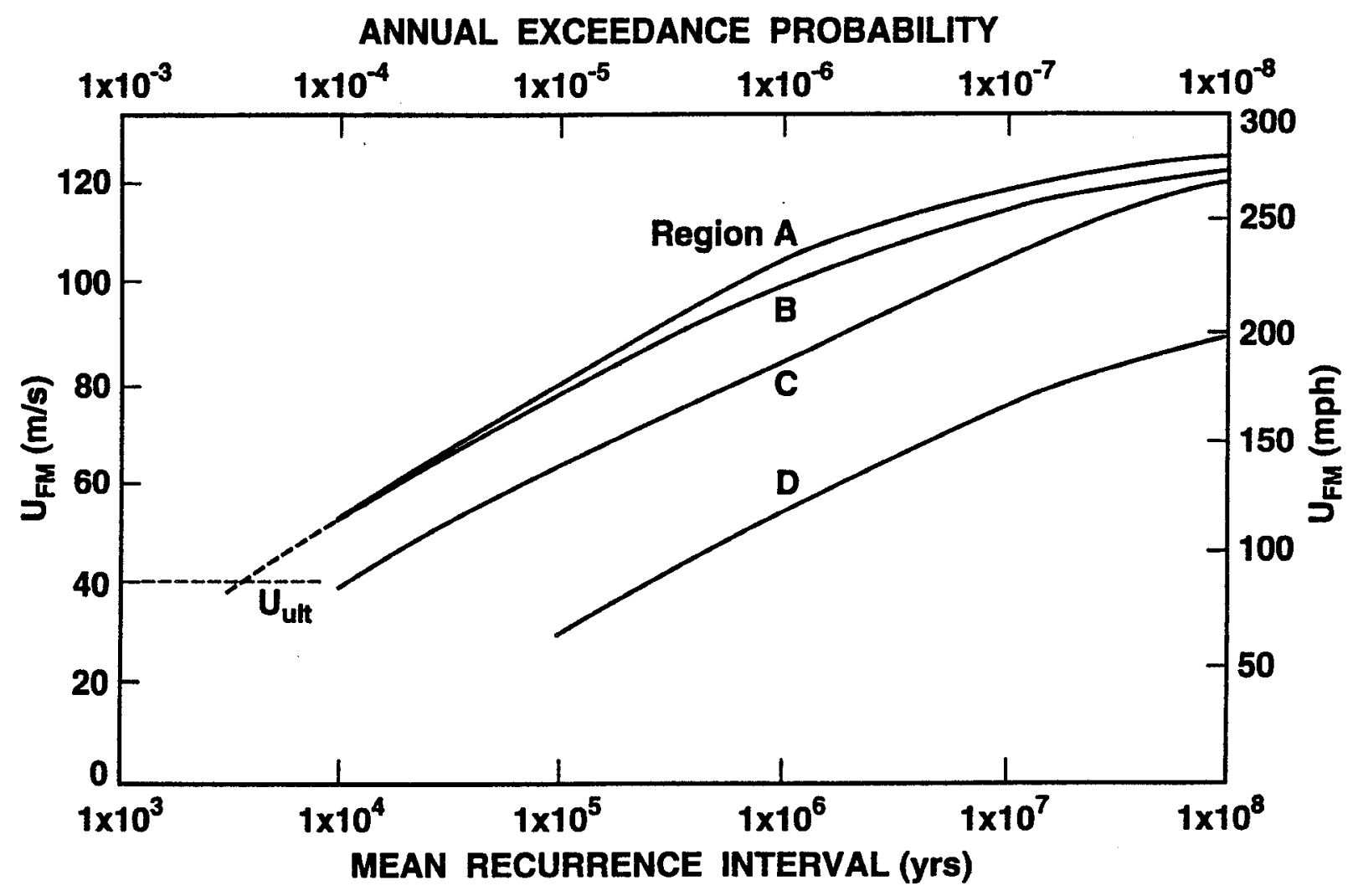

Figure 4. Mean regional tornado wind speed exceedance probabilities for point targets (Twisdale and Dunn 1983).

\subsection{WIND FORCES ACTING ON SUPPORT AND ANCHORING SYSTEMS}

\subsection{Nominal Wind Loads}

Wind loads, dead loads and reactions for traditional frame ties and piers are defined in Figure 5. The nominal drag and uplift loads corresponding to the three wind speed zones designated in MHCSS-94 are listed in Table 4 for single- and for double-wide manufactured homes of typical dimensions and geometry sited in a category $C$ exposure. Also listed in Table 4 are the corresponding nominal drag and uplift loads specified by ASCE 7-93 for a range of basic wind speeds in Zone I and for basic wind speeds of 44.7 and $49.2 \mathrm{~m} / \mathrm{s}(100$ and $110 \mathrm{mph}$ ) in Zones II and III, respectively. For details on the development of the loads listed in Table 4, see Marshall 1993, 1994. Although the ASCE 7-93 basic wind speeds in Zone I do not exceed 40.2 $\mathrm{m} / \mathrm{s}$ (90 mph), loads corresponding to $44.7 \mathrm{~m} / \mathrm{s}(100 \mathrm{mph})$ are included for comparison with the 
loads for wind Zone II (hurricane-prone region). Consistent with the requirements of ASCE 793 for hurricane-prone regions, the basic wind speeds for Zones II and III have been multiplied by a structure importance factor of 1.05 in calculating the nominal drag and uplift loads.

It is seen from Table 4 that the wind loads specified by MHCSS-94 for wind Zone I are slightly lower than those of ASCE 7-93 for a basic wind speed of $31.3 \mathrm{~m} / \mathrm{s}(70 \mathrm{mph})$, this being the minimum basic wind speed allowed by ASCE 7-93. For wind Zones II and III the differences in nominal wind loads specified by MHCSS- 94 and by ASCE 7-93 are due to simplifications of the load distributions adopted by MHCSS-94.

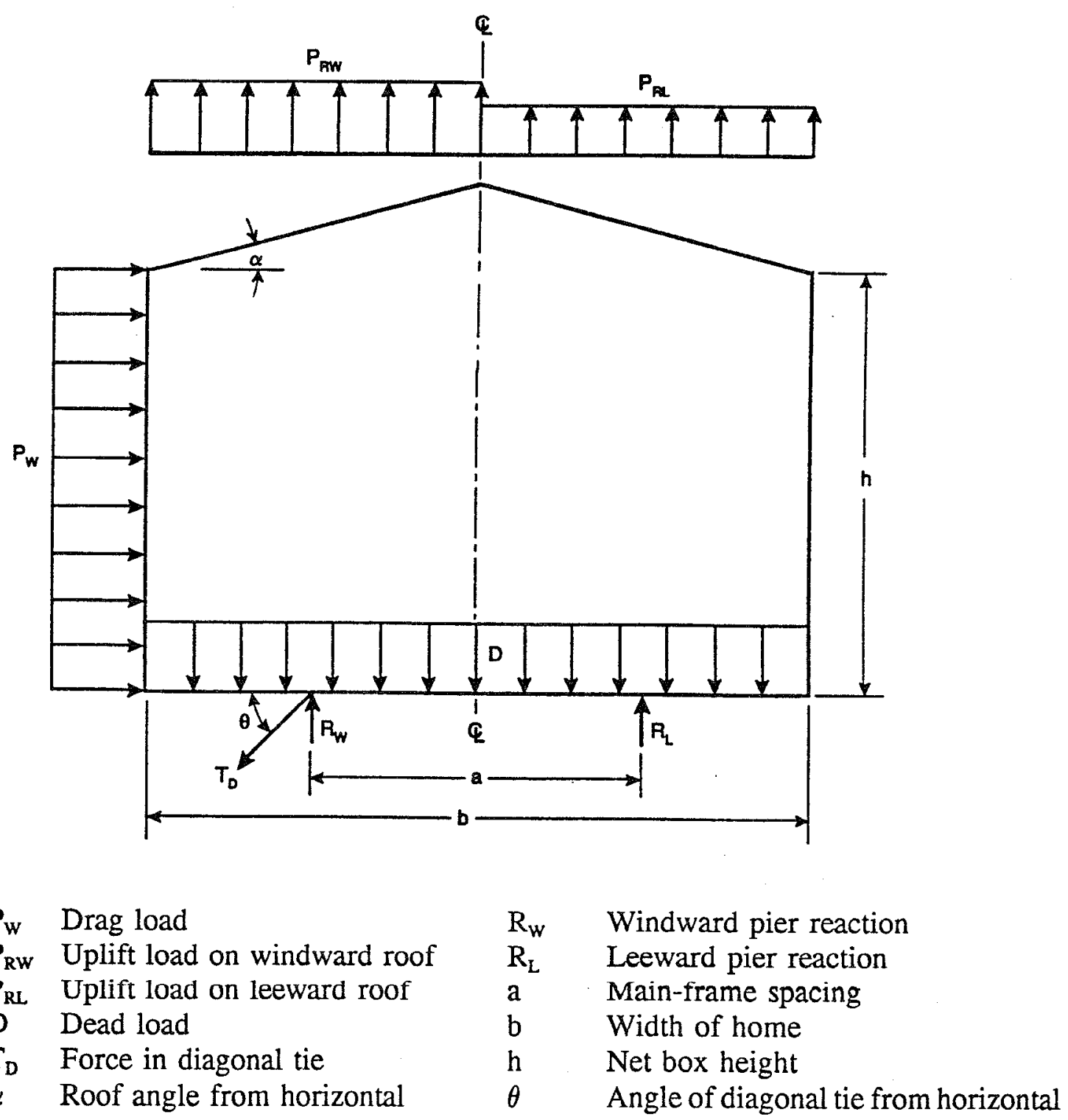

Figure 5. Loads and reactions for traditional diagonal frame-ties and piers 
Table 4. Nominal Wind Loads for Single- and Double-Wide Manufactured Homes (Angle of plane of roof from horizontal $=15$ degrees)

\begin{tabular}{llllll}
\hline Basic Wind Speed & \multicolumn{2}{c}{ Net Drag Load } & \multicolumn{2}{c}{ Uplift } & Uplift \\
Windward Roof & Leeward Roof \\
$(\mathrm{m} / \mathrm{s})$ & $(\mathrm{mph})$ & $(\mathrm{kPa})$ & $(\mathrm{psf})$ & $(\mathrm{kPa}) \quad(\mathrm{psf})$ & $(\mathrm{kPa}) \quad(\mathrm{psf})$
\end{tabular}

Zone I

$\begin{array}{lllllll}\text { MHCSS-94 } & 0.72 & (15) & 0.43 & \text { (9) } & 0.43 & \text { (9) }\end{array}$

ASCE 7-93

$\begin{array}{rrrrrrrr}31.3 & (70) & 0.82 & (17.2) & 0.57 & (11.9) & 0.45 & (9.3) \\ 35.8 & (80) & 1.08 & (22.5) & 0.75 & (15.6) & 0.58 & (12.1) \\ 40.2 & (90) & 1.36 & (28.5) & 0.94 & (19.7) & 0.73 & (15.3) \\ 44.7 & (100) & 1.69 & (35.2) & 1.17 & (24.4) & 0.90 & (18.9)\end{array}$

Zone II (Hurricane)

$\begin{array}{lllllll}\text { MHCSS (Old) } & & 1.20 & \text { (25) } & 0.72 & \text { (15) } & 0.72\end{array}$

$\begin{array}{llllll}\text { MHCSS-94 } & 1.87 & (39) & 1.29 & (27) & 1.29\end{array}$

ASCE 7-93

$\begin{array}{llllllll}44.7 & (100) & 1.86 & (38.8) & 1.29 & (26.9) & 1.00 & (20.8)\end{array}$

Zone III (Hurricane)

$\begin{array}{llllll}\text { MHCSS (Old)* } & 1.20 & \text { (25) } & 0.72 & \text { (15) } & 0.72\end{array}$

$\begin{array}{lllllll}\text { MHCSS-94 } & 2.25 & (47) & 1.53 & \text { (32) } & 1.53 & \text { (32) }\end{array}$

ASCE 7-93

$\begin{array}{lllllllll}49.2 & (110) & 2.25 & (46.9) & 1.56 & (32.5) & 1.21 & (25.2)\end{array}$

* Prior to 1994 and presented for comparison with MHCSS-94. Note that the former Zone II (Hurricane Resistive) does not correspond exactly with MHCSS-94 Zones II and III. 


\subsection{Diagonal Frame-Tie and Pier Reactions for Single-Wide Homes Due to Wind plus Dead Load}

Using the appropriate nominal wind loads listed in Table 4, the loads per unit length of home to be resisted by the diagonal frame ties and by the piers for wind Zones I, II and III are listed in Tables 5, 6 and 7, respectively. The nominal loads listed in Table 4 and the corresponding reactions are based on the following assumptions:

Width of home $=4.267 \mathrm{~m}(14 \mathrm{ft})$

Net box height $=2.438 \mathrm{~m}(8 \mathrm{ft})$

Roof slope $=15$ degrees

Center-to-center pier or main-frame spacing $=2.134 \mathrm{~m}(7 \mathrm{ft})$

Angle of diagonal tie $=45$ degrees

Nominal dead load $=1.20 \mathrm{kPa}(25 \mathrm{psf})$ acting through geometric center of home

Typical calculations are presented in Appendix A. It is assumed in the calculations that the piers provide no lateral resistance. Although it is possible to estimate this lateral resistance, the lateral stiffness of the soil anchor must be known as must the height and width of the pier and the location of the pier load. Since NCSBCS/ANSI A225.1-94 places no limitation on anchor head displacement it is not possible to assess anchor stiffness and hence the lateral resistance of the piers must be assumed to be zero. Consistent with the requirements of MHCSS-94 and of ASCE $7-93$, the factored loads are obtained by multiplying the nominal loads by a dead load factor $\gamma_{D}$ and a wind load factor $\gamma_{\mathrm{w}}$ as follows:

$\begin{array}{ccc} & \gamma_{\mathrm{D}} & \gamma_{\mathrm{W}} \\ \text { MHCSS-94 } & 1.0 & 1.5 \\ \text { ASCE 7-93 } & 0.9 & 1.3\end{array}$

Note that MHCSS-94 uses an allowable stress design (ASD) format throughout, and only the wind loads in Zone I are multiplied by a factor of 1.5 when designing components for windstorm protection. Nominal wind loads are used by MHCSS-94 for the design of these components in Zones II and III. Also, while the loads listed in Tables 5 to 7 are for single-wide homes, the diagonal tie loads apply to double-wide homes as well. A listing of the computer program used to generate the loads tabulated in Tables 5 to 7 and a sample program output can be found in Appendix B. 
Table 5. Zone I Single-Wide Loads for Diagonal Frame-Ties and for Piers

\begin{tabular}{|c|c|c|c|}
\hline $\begin{array}{l}\text { Basic Wind Speed } \\
(\mathrm{m} / \mathrm{s}) \quad(\mathrm{mph})\end{array}$ & $\begin{array}{c}\text { Diagonal Tie } \\
(\mathrm{kN} / \mathrm{m}) \quad(\mathrm{lbf} / \mathrm{ft})\end{array}$ & $\begin{array}{l}\text { Windward Pier } \\
(\mathrm{kN} / \mathrm{m}) \quad(\mathrm{lbf} / \mathrm{ft})\end{array}$ & $\begin{array}{l}\text { Leeward Pier } \\
(\mathrm{kN} / \mathrm{m}) \quad(\mathrm{lbf} / \mathrm{ft})\end{array}$ \\
\hline
\end{tabular}

Nominal Loads

$\begin{array}{lllllll}\text { MHCSS-94 } & 2.48 & (170) & 2.38 & (163) & 2.64 & \text { (181) }\end{array}$

ASCE 7-93

$\begin{array}{lrllllll}31.3 & (70) & 2.84 & (195) & 2.20 & (151) & 2.75 & (189) \\ 35.8 & (80) & 3.71 & (255) & 2.09 & (143) & 2.82 & (193) \\ 40.2 & (90) & 4.71 & (322) & 1.97 & (135) & 2.89 & (198) \\ 44.7 & (100) & 5.81 & (398) & 1.82 & (125) & 2.97 & (204)\end{array}$

Factored Loads

MHCSS-94

$3.71 \quad(255)$

$2.30 \quad(158)$

$2.68 \quad(183)$

ASCE 7-93

$\begin{array}{rrrlllll}31.3 & (70) & 3.69 & (253) & 1.84 & (126) & 2.56 & (175) \\ 35.8 & (80) & 4.83 & (331) & 1.69 & (116) & 2.64 & (181) \\ 40.2 & (90) & 6.12 & (419) & 1.54 & (105) & 2.74 & (188) \\ 44.7 & (100) & 7.55 & (518) & 1.35 & (92) & 2.84 & (195)\end{array}$

Note: Loads are for $\theta=45$ degrees 
Table 6. Zone II Single-Wide Loads for Diagonal Frame-Ties and for Piers Basic Wind Speed $=44.7 \mathrm{~m} / \mathrm{s}(100 \mathrm{mph})$

$\begin{array}{clc}\text { Diagonal Tie } & \text { Windward Pier } & \text { Leeward Pier } \\ (\mathrm{kN} / \mathrm{m})(\mathrm{lbf} / \mathrm{ft}) & (\mathrm{kN} / \mathrm{m})(\mathrm{lbf} / \mathrm{ft}) & (\mathrm{kN} / \mathrm{m})(\mathrm{lbf} / \mathrm{ft})\end{array}$

Nominal Loads

$\begin{array}{lllllll}\text { MHCSS (Old) } & 4.13 & (282) & 2.27 & (156) & 2.69 & (184) \\ \text { MHCSS-94 } & 6.44 & (441) & 1.75 & (120) & 2.40 & (164) \\ \text { ASCE 7-93 } & 6.41 & (439) & 1.75 & (120) & 3.02 & (207)\end{array}$

Factored Loads

$\begin{array}{lllllll}\text { MHCSS (Old) } & 6.19 & (424) & 2.13 & (146) & 2.76 & (189) \\ \text { ASCE 7-93 } & 8.33 & (571) & 1.25 & (86) & 2.90 & (199)\end{array}$

Note: Loads are for $\theta=45$ degrees

Table 7. Zone III Single-Wide Loads for Diagonal Frame-Ties and for Piers Basic Wind Speed $=49.2 \mathrm{~m} / \mathrm{s}(110 \mathrm{mph})$

\begin{tabular}{clc}
\multicolumn{1}{c}{ Diagonal Tie } & Windward Pier & Leeward Pier \\
$(\mathrm{kN} / \mathrm{m})(\mathrm{lbf} / \mathrm{ft})$ & $(\mathrm{kN} / \mathrm{m})(\mathrm{lbf} / \mathrm{ft})$ & $(\mathrm{kN} / \mathrm{m})(\mathrm{lbf} / \mathrm{ft})$
\end{tabular}

Nominal Loads

$\begin{array}{lllllll}\text { MHCSS (Old) } & 4.13 & (282) & 2.27 & (156) & 2.69 & (184) \\ \text { MHCSS-94 } & 7.76 & (532) & 1.64 & (112) & 2.42 & (166) \\ \text { ASCE 7-93 } & 7.74 & (531) & 1.58 & (108) & 3.11 & (213)\end{array}$

Factored Loads

$\begin{array}{lrllrll}\text { MHCSS (Old) } & 6.19 & (424) & 2.13 & (146) & 2.76 & (189) \\ \text { ASCE 7-93 } & 10.07 & (690) & 1.03 & (71) & 3.02 & \text { (207) }\end{array}$

Note: Loads are for $\theta=45$ degrees 


\subsection{Main-Frame Reactions for Single-Wide Homes Due to Wind plus Dead Load}

The loads per unit length of home as presented in Tables 5 to 7 are based on the assumption that the drag load is resisted by diagonal frame ties installed at an angle of 45 degrees with the horizontal and that the vertical reactions are developed by individual (windward and leeward) piers that resist vertical compressive loads only. An alternate formulation of the support system reactions is the horizontal shear and vertical forces per unit length of home acting on the main frame as indicated in Figure 6. The resulting forces are directly applicable to the design of alternative supporting systems such as post and beam, moment frames, and shear walls. The calculated reactions for nominal loads and for factored loads are listed for wind Zones I, II and III in Tables 8, 9 and 10, respectively. Because there is no diagonal tie to contribute a downward vertical component of load, the resulting windward vertical reactions, $R_{w}$, listed in Tables 8 to 10 can assume negative values, indicating a net uplift. In such cases, the windward support must be capable of resisting uplift forces. The horizontal shear to be resisted by the support system is the total horizontal shear, and the proportioning between windward and leeward reactions will depend on the details of the support system.

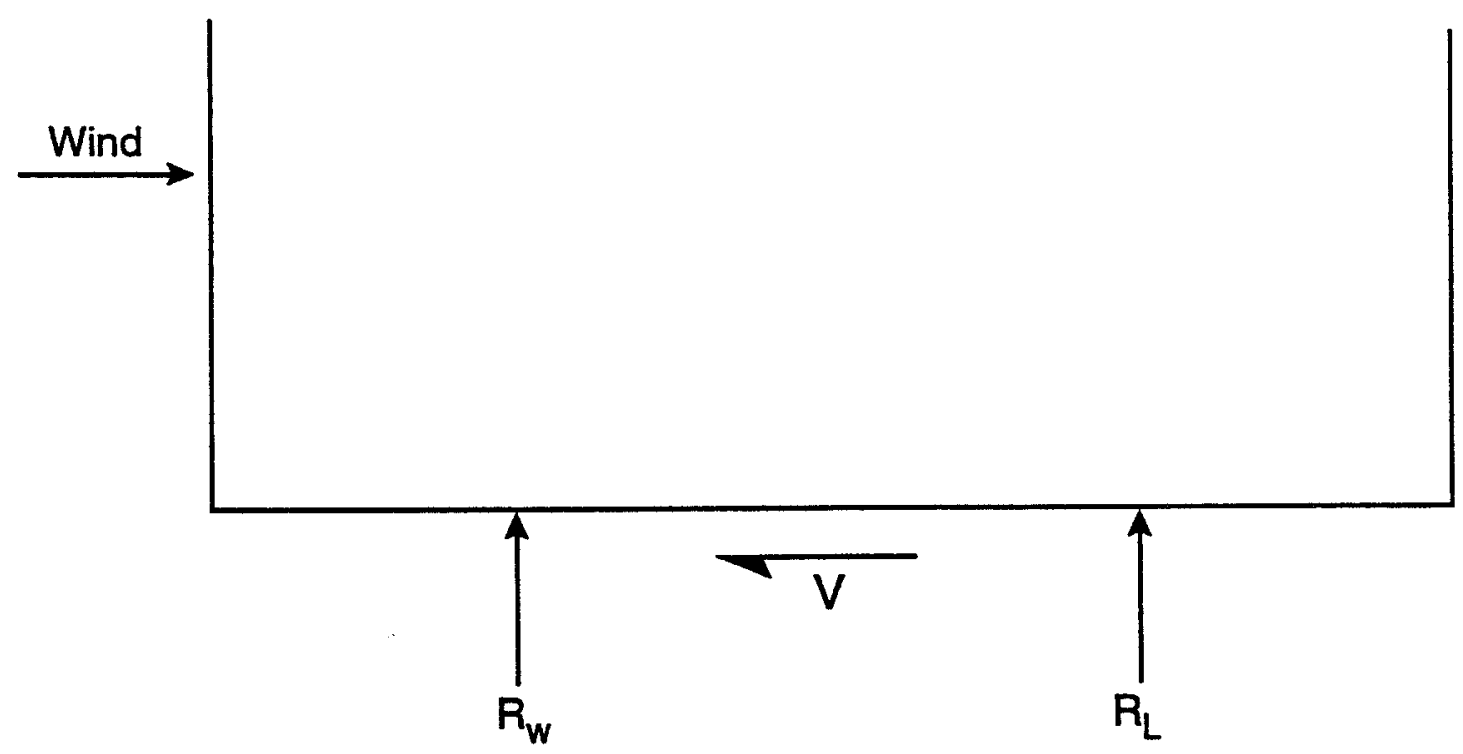

Figure 6. Reactions in terms of horizontal shear and vertical forces acting on main frame 
Table 8. Zone I Single-Wide Main-Frame Reactions

Basic Wind Speed

$(\mathrm{m} / \mathrm{s}) \quad(\mathrm{mph})$
Horizontal Shear

$(\mathrm{kN} / \mathrm{m})(\mathrm{lbf} / \mathrm{ft})$
Windward Support

$(\mathrm{kN} / \mathrm{m}) \cdot(\mathrm{lbf} / \mathrm{ft})$
Leeward Support

$(\mathrm{kN} / \mathrm{m}) \quad(\mathrm{lbf} / \mathrm{ft})$

Nominal Loads

MHCSS-94

$1.75 \quad(120)$

0.63

(43)

2.64

ASCE 7-93

$\begin{array}{rrrrrrrr}31.3 & (70) & 2.01 & (138) & 0.19 & (13) & 2.75 & (189) \\ 35.8 & (80) & 2.63 & (180) & -0.54 & (-37) & 2.82 & (193) \\ 40.2 & (90) & 3.33 & (228) & -1.36 & (-93) & 2.89 & (198) \\ 44.7 & (100) & 4.11 & (282) & -2.29 & (-157) & 2.97 & (204)\end{array}$

Factored Loads

MHCSS-94

$2.63 \quad(180)$

$-0.33 \quad(-22)$

2.68

ASCE 7-93

$\begin{array}{rrrlllll}31.3 & (70) & 2.61 & (179) & -0.77 & (-53) & 2.56 & (175) \\ 35.8 & (80) & 3.41 & (234) & -1.72 & (-118) & 2.64 & (181) \\ 40.2 & (90) & 4.33 & (296) & -2.79 & (-191) & 2.74 & (188) \\ 44.7 & (100) & 5.34 & (366) & -3.99 & (-274) & 2.84 & (195)\end{array}$

Note: Negative sign indicates uplift. Main-frame spacing $=2.134 \mathrm{~m}(7 \mathrm{ft})$. 
Table 9. Zone II Single-Wide Main-Frame Reactions

Basic Wind Speed $=44.7 \mathrm{~m} / \mathrm{s}(100 \mathrm{mph})$

Horizontal Shear

$(\mathrm{kN} / \mathrm{m}) \quad(\mathrm{lbf} / \mathrm{ft})$
Windward Support $(\mathrm{kN} / \mathrm{m}) \quad(\mathrm{lbf} / \mathrm{ft})$
Leeward Support

$(\mathrm{kN} / \mathrm{m}) \quad(\mathrm{lbf} / \mathrm{ft})$

Nominal Loads

MHCSS (Old)

MHCSS-94

$2.92 \quad(200)$

$\begin{array}{ll}-0.65 & (-44)\end{array}$

2.69

$-2.81 \quad(-192)$

2.40

(184)

$4.55 \quad(312)$

$-2.78(-191)$

3.02

(164)

(310)

(207)

Factored Loads

MHCSS (Old)

ASCE 7-93

$\begin{array}{ll}4.38 & (300) \\ 5.89 & (404)\end{array}$

$-2.25(-154)$

2.76

$-4.64(-318)$

2.90

(199)

Note: Negative sign indicates uplift. Main-frame spacing $=2.134 \mathrm{~m}(7 \mathrm{ft})$.

Table 10. Zone III Single-Wide Main-Frame Reactions

Basic Wind Speed $=49.2 \mathrm{~m} / \mathrm{s}(110 \mathrm{mph})$

Horizontal Shear

$(\mathrm{kN} / \mathrm{m}) \quad(\mathrm{lbf} / \mathrm{ft})$
Windward Support

$(\mathrm{kN} / \mathrm{m}) \quad(\mathrm{lbf} / \mathrm{ft})$
Leeward Support

$(\mathrm{kN} / \mathrm{m}) \quad(\mathrm{lbf} / \mathrm{ft})$

Nominal Loads

$\begin{array}{lllllll}\text { MHCSS (Old) } & 2.92 & (200) & -0.65 & (-44) & 2.69 & (184) \\ \text { MHCSS-94 } & 5.49 & (376) & -3.85 & (-264) & 2.42 & (166) \\ \text { ASCE 7-93 } & 5.48 & (375) & -3.89 & (-267) & 3.11 & (213)\end{array}$

Factored Loads

MHCSS (Old)

ASCE 7-93

$\begin{array}{ll}4.38 & (300) \\ 7.12 & (488)\end{array}$

$-2.25 \quad(-154)$

2.76

(189)

$-6.08 \quad(-417)$

3.02

(207)

Note: Negative sign indicates uplift. Main-frame spacing $=2.134 \mathrm{~m}(7 \mathrm{ft})$. 


\subsection{ANCHORAGE REQUIREMENTS FOR EARTHQUAKE LOADS}

\subsection{Background}

The Northridge Earthquake of 1994 once again demonstrated the importance of adequate resistance to lateral movement of manufactured homes supported by traditional concrete block piers or steel jackstands (NCSBCS 1994). In one manufactured home park there were at least six individual ignitions of leaking natural gas due to excessive movement of homes on their supports (Todd et al. 1994). Performance of manufactured home support systems appears to have been similar to that observed in the San Fernando Earthquake of 1971.

\subsection{Requirements of the Uniform Building Code}

The Uniform Building Code (UBC-94) requires a total design base shear

$$
\mathrm{V}=\left(\mathrm{ZIC} / \mathrm{R}_{\mathrm{w}}\right) \mathrm{W}
$$

where $\mathrm{Z}$ is a seismic zone factor, $\mathrm{I}$ is an importance factor, $R_{w}$ is a response modification coefficient that depends on the basic structural system, and $\mathrm{W}$ is the total seismic dead load which includes the conventional dead load and applicable portions of other loads as specified in UBC-94. C is a numerical coefficient obtained from the relationship

$$
\mathrm{C}=1.25 \mathrm{~S} / \mathrm{T}^{2 / 3}
$$

where $S$ is a site coefficient that accounts for the local soil characteristics, and $T$ is the fundamental period of vibration of the structure in the direction under consideration. According to UBC-94, the value of $\mathrm{T}$ may be estimated from the formula:

$$
\mathrm{T}=\mathrm{C}_{\mathrm{t}}\left(\mathrm{h}_{\mathrm{n}}\right)^{3 / 4}
$$

where $C_{t}=0.020$ for the type of construction considered here, and $h_{n}$ is that level (expressed in feet) which is uppermost in the main portion of the structure. If $h_{n}$ is assumed to be $3.5 \mathrm{~m}$ $(11.48 \mathrm{ft})$, the corresponding value of $\mathrm{T}$ is $0.12 \mathrm{~s}$.

Actual measurements of a manufactured home superstructure vibrating in the transverse direction (Marshall 1977) indicate a first-mode frequency of approximately $4 \mathrm{~Hz}$ (period $\mathrm{T}=0.25 \mathrm{~s}$ ). However, the corresponding frequency of the combined superstructure, main frame, and tiedown system is believed to be closer to $2 \mathrm{~Hz}(\mathrm{~T}=0.5 \mathrm{~s}$ ), based on typical manufactured home dead loads and soil anchor stiffness. In the longitudinal direction, the direction in which the design base shear for earthquakes more often exceeds the design drag load for wind, a fundamental period of less than $0.5 \mathrm{~s}$ can be expected because of the greater length of wall available for shear transfer. Although no actual measurements of manufactured home modal frequencies in the longitudinal direction are available, it is doubtful that the period of the fundamental mode will be shorter than the value given by Equation 4-3. 
In locations where the soil properties are not known in sufficient detail to determine the soil profile type, UBC-94 requires the selection of soil profile type $S_{3}$, and the corresponding site coefficient is $S=1.5$. For this value of $S$ and a period of $0.5 \mathrm{~s}$, equation 4-2 yields a value of $\mathrm{C}=2.98$. However, UBC-94 states that the value of $\mathrm{C}$ need not exceed 2.75 and this value may be used for any structure without regard to soil type or structure period. Consequently, if soil profile $S_{3}$ is assumed, $C$ does not increase for natural periods shorter than about $0.56 \mathrm{~s}$ which is believed to cover the range of fundamental periods applicable to manufactured homes.

For manufactured homes the value of $I=1.0$ is appropriate. The value of $R_{w}$ very much depends on the type of structural system, its ductility under reverse cycles of earthquake load, and the type of foundation. UBC-94 specifies values of $R_{w}$ for "Light-framed walls with shear panels." The values are $R_{\mathrm{w}}=8$ for "Wood structural panel walls for structures three stories or less," and $R_{w}=6$ for "All other light-framed walls." Use of $R_{w}=8$ assumes that all relevant requirements of UBC-94 for wood structural panel walls are satisfied. In consideration of the fact that manufactured homes usually are supported by temporary foundations and generally are not built to the same requirements as conventional wood construction covered by the Uniform Building Code, it can be argued that $R_{w}=6$ is an appropriate value for the response modification factor. If seismic zone 4 is assumed, then $Z=0.4$ and from Equation 4-1 the required base shear for $R_{w}=6$ becomes:

$$
\mathrm{V}=[(0.4)(1.0)(2.75) / 6](\mathrm{W})=0.183 \mathrm{~W}
$$

For $R_{w}=8$, the required base shear is

$$
\mathrm{V}=[(0.4)(1.0)(2.75) / 8](\mathrm{W})=0.138 \mathrm{~W}
$$

\subsection{Requirements of ASCE 7-93}

The ASCE 7-93 requirements for earthquake loads are taken from the NEHRP Recommended Provisions for the Development of Seismic Regulations for New Buildings (NEHRP 1991). The seismic base shear, $\mathrm{V}$, is given by the relationship

$$
\mathrm{V}=\mathrm{C}_{\mathrm{s}} \mathrm{W}
$$

where $\mathrm{C}_{\mathbf{s}}$ is the seismic design coefficient and $\mathrm{W}$ is the sum of the dead load and applicable portions of other loads as noted in the previous discussion of the UBC-94 requirements. The seismic design coefficient is obtained from the relationship

$$
\mathrm{C}_{\mathrm{s}}=1.2 \mathrm{~A} \mathrm{v} /\left(\mathrm{RT}^{2 / 3}\right)
$$

where $A_{v}$ is a coefficient representing the effective peak velocity-related acceleration, $S$ and $T$ are as defined previously, and $\mathrm{R}$ is the response modification coefficient (the post-yield counterpart of $R_{w}$ in UBC-94). Detached one- and two-family dwellings located in seismic map areas having values of $A_{v}$ less than 0.15 are exempt from the earthquake load requirements. 
Alternatively, the seismic design coefficient required by ASCE 7-93 need not be greater than

$$
\mathrm{C}_{\mathrm{s}}=2.5 \mathrm{~A}_{\mathrm{a}} / \mathrm{R}
$$

where $A_{a}$ is the seismic design coefficient representing the effective peak acceleration. When $A_{a}=A_{v}$ and $S=1.5$ (soil profile type $S_{3}$ ) the value of $C_{S}$ will be independent of the fundamental period of vibration, $T$, for periods shorter than about $0.61 \mathrm{~s}$. For "Light frame walls with shear panels," ASCE 7-93 specifies a value of $R=6.5$ for the response modification coefficient, and for $\mathrm{A}_{\mathrm{a}}=0.4$ the corresponding value of the seismic design coefficient will be $\mathrm{C}_{\mathrm{s}}=0.154$. The corresponding seismic base shear becomes

$$
\mathrm{V}=0.154 \mathrm{~W}
$$

The relationships between fundamental period, $T$, and $Z I C / R_{w}$ for UBC- 94 and $C_{s}$ for ASCE 7-93 are shown in Figure 7. A value of $R_{w}=6$ has been assumed in the UBC-94 plot. It can be seen from Figure 7 that the range of fundamental periods for manufactured homes (taken as 0.2 to $0.5 \mathrm{~s}$ ) falls on the plateau region of each curve. Also, the UBC-94 requirement is seen to be slightly more conservative than that of ASCE 7-93 when a value of $R_{w}=6$ is assumed $\left(\mathrm{ZIC} / \mathrm{R}_{\mathrm{w}}=0.183\right.$ vs. $\left.\mathrm{C}_{\mathrm{s}}=0.154\right)$. Implicit in the UBC-94 requirements is an allowable stress design (ASD) approach while the ASCE-93 requirements are based on the assumption of postyield structural behavior. This apparent inconsistency is removed when $\mathrm{R}_{\mathrm{w}}=8\left(\mathrm{ZIC} / \mathrm{R}_{\mathrm{w}}=\right.$ 0.138 vs. $\left.\mathrm{C}_{\mathrm{s}}=0.154\right)$.

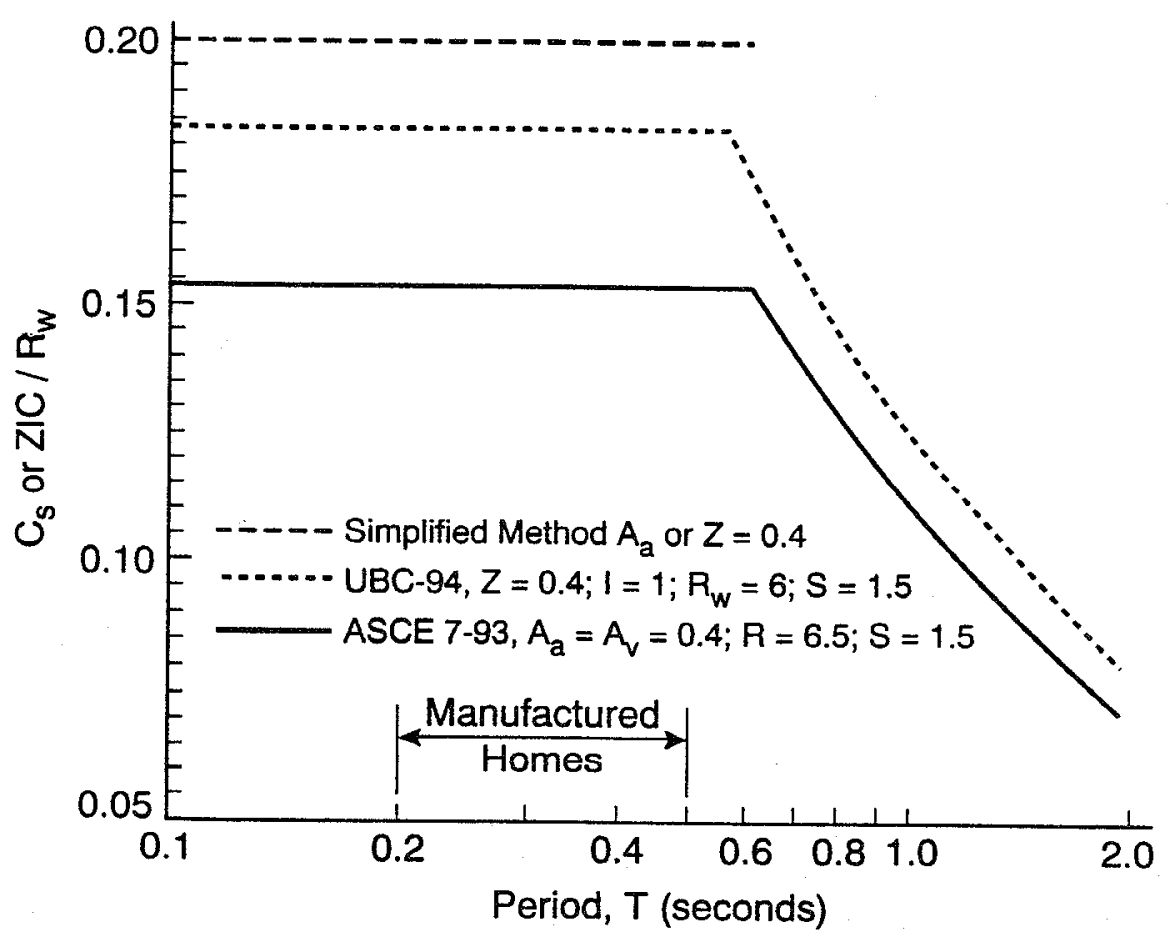

Figure 7. Relationship between fundamental period $\mathrm{T}$ and $\mathrm{C}_{\mathrm{s}}$ or $\mathrm{ZIC} / \mathrm{R}_{\mathrm{w}}$ 


\subsection{A Simplified Base Shear Equation}

In view of the fact that there is considerable uncertainty about the dynamic properties of manufactured homes and their support systems, their behavior under reversed cycles of earthquake loading, and the desirability of having a uniform design approach that is applicable to all areas for which $\mathrm{A}_{\mathrm{a}}$ or $\mathrm{Z}$ exceeds 0.2 , the following simplified requirement is proposed:

$$
\mathrm{V}=0.5 \mathrm{ZW} \text { or } 0.5 \mathrm{~A}_{\mathrm{a}} \mathrm{W} \quad\left(\mathrm{Z} \text { or } \mathrm{A}_{\mathrm{a}} \geq 0.2\right)
$$

where $\mathrm{V}, \mathrm{Z}, \mathrm{A}_{\mathrm{a}}$ and $\mathrm{W}$ are as defined previously. This simplified requirement is represented by the upper horizontal line in Figure 7.

\subsection{Seismic Dead Load and Overturning Moment at the Foundation Level}

Both UBC-94 and ASCE 7-93 define the seismic dead load, W, as the total dead load and applicable portions of other loads such as floor live loads in storage occupancies, partition loads, snow load, and the total weight of permanent equipment. Design snow loads of $1.44 \mathrm{kPa}(30$ psf) or less need not be included in the seismic dead load. Where design snow loads exceed this value, snow loads are included but may be reduced up to 75 percent if warranted by siting, roof configuration, or load duration. In previous calculations involving combined wind and dead load, a unit dead load of $1.20 \mathrm{kPa}$ (25 psf) was assumed. While the vertical distribution of the dead load is not of interest in calculating stability under wind loading, this distribution must be known or estimated when calculating reactions due to earthquake loading. The vertical distribution of horizontal earthquake forces for buildings with a fundamental period of $0.5 \mathrm{~s}$ or less is specified in Section 9.4.3 of ASCE 7-93, and an identical equation is used in UBC-94 for structures having a fundamental period of $0.7 \mathrm{~s}$ or less. The vertical distribution of forces is given by the following relationships:

$$
\mathrm{F}_{\mathrm{x}}=\mathrm{C}_{\mathrm{vx}} \mathrm{V}
$$

and

$$
C_{v x}=\left(w_{x} h_{x}\right) / \sum_{i=1}^{n}\left(w_{i} h_{i}\right)
$$

where $F_{x}$ is the lateral force assigned to level $x ; C_{v x}$ is a vertical distribution factor for appropriate portions of the total base shear; subscripts $i$ and $x$ designate portions of the dead load assigned to levels $h_{i}$ or $h_{x}$; and the summation is performed from level $i=1$ to level $n$.

In estimating the action line of the resultant horizontal earthquake force the following manufactured home dimensions and dead loads have been assumed:

Width of home $=4.267 \mathrm{~m}(14 \mathrm{ft})$

Wall height $=2.438 \mathrm{~m}(8 \mathrm{ft})$

Height of roof dead load above floor $=2.591 \mathrm{~m}(8.5 \mathrm{ft})$ 
Height of floor diaphragm above ground $=0.914 \mathrm{~m}(3 \mathrm{ft})$

Wall and partition area per unit length of home $=6.096 \mathrm{~m}^{2} / \mathrm{m}\left(20 \mathrm{ft}^{2} / \mathrm{ft}\right)$

Floor dead load $=479 \mathrm{~Pa}(10 \mathrm{psf})$

Roof dead load $=479 \mathrm{~Pa}$ (10 psf)

Wall and partition load per unit length of home $=215 \mathrm{~Pa}$ (4.5 psf)

Storage and equipment dead load $=239 \mathrm{~Pa}$ (5 psf)

For $A_{\mathbf{a}}=0.4$ and using the simplified requirement for base shear (Equation 4-9), the total seismic dead load and base shear per unit length of manufactured home are as follows:

$$
\begin{aligned}
& \mathrm{W}=(479+479+239)(4.267)+(215)(6.096)=6,418 \mathrm{~N} / \mathrm{m} \quad(440 \mathrm{lbf} / \mathrm{ft}) \\
& \mathrm{V}=(0.5)(0.4)(6,418)=1,284 \mathrm{~N} / \mathrm{m} \quad(88 \mathrm{lbf} / \mathrm{ft})
\end{aligned}
$$

The vertical distribution of the base shear is determined as follows:

$$
\begin{aligned}
\Sigma\left(\mathrm{w}_{\mathrm{i}} \mathrm{h}_{\mathrm{i}}\right)= & (479+239)(4.267)(0.914)+(215)(6.096)(0.914+2.438 / 2) \\
& +(479)(4.267)(0.914+2.591) \\
= & 2,800+2,796+7,164=12,760 \mathrm{~N}-\mathrm{m} / \mathrm{m} \quad(2,870 \mathrm{lbf}-\mathrm{ft} / \mathrm{ft})
\end{aligned}
$$

At floor: $\quad \mathrm{C}_{\mathrm{vx}}=2,800 / 12,760=0.219$

$$
\mathrm{F}_{\mathrm{x}}=(0.219)(1,284)=281 \mathrm{~N} / \mathrm{m} \quad(19.3 \mathrm{lbf} / \mathrm{ft})
$$

At walls: $\quad \mathrm{C}_{\mathrm{vx}}=2,796 / 12,760=0.219$

$$
\mathrm{F}_{\mathrm{x}}=(0.219)(1,284)=281 \mathrm{~N} / \mathrm{m}(19.3 \mathrm{lbf} / \mathrm{ft})
$$

At roof: $\quad \mathrm{C}_{\mathrm{vx}}=7,164 / 12,760=0.562$

$$
\mathrm{F}_{\mathrm{x}}=(0.562)(1,284)=722 \mathrm{~N} / \mathrm{m} \quad(49.4 \mathrm{lbf} / \mathrm{ft})
$$

The location of the action line of the resultant horizontal earthquake force above ground level would be

$$
\mathrm{H}=[(281)(0.914)+(281)(2.133)+(722)(3.505)] / 1,284=2.638 \mathrm{~m}(8.65 \mathrm{ft})
$$

Thus the resultant horizontal earthquake force would act approximately $1.72 \mathrm{~m}(5.65 \mathrm{ft})$ above the level of the floor diaphragm. This height would increase where snow loads need to be considered and would decrease if a larger fraction of the design floor live load were included in the total seismic dead load. This line of action is slightly higher than that of the drag component of the wind load which is assumed to act at mid-height of the walls. However, because of the relatively higher lateral loads and uplift loads acting on the roof, the overturning moment due to wind is substantially larger than that due to earthquake forces. For example, in the case just considered, the earthquake overturning moment about the top of a leeward pier located $305 \mathrm{~mm}(1 \mathrm{ft})$ below the floor diaphragm would be as follows: 


$$
\mathrm{M}_{\mathrm{s}}=(1.284)(2.638-0.610)=2.60 \mathrm{kN}-\mathrm{m} / \mathrm{m}(585 \mathrm{lbf}-\mathrm{ft} / \mathrm{ft})
$$

With reference to the nominal drag and uplift loads listed in Table 4 for a wind speed of 31.3 $\mathrm{m} / \mathrm{s}(70 \mathrm{mph})$ and a main-frame spacing of $2.134 \mathrm{~m}(7 \mathrm{ft})$, the corresponding factored wind load overturning moment about the top of a leeward pier is as follows:

$$
\begin{aligned}
\mathrm{M}_{\mathrm{w}} & =(1.3)[(0.82)(2.438)(2.438 / 2+0.305)+(0.57)(4.267 / 2)(4.267 / 2)] \\
& =7.33 \mathrm{kN}-\mathrm{m} / \mathrm{m} \quad(1,650 \mathrm{lbf}-\mathrm{ft} / \mathrm{ft})
\end{aligned}
$$

Thus the overtuming moment for a design wind speed of $31.3 \mathrm{~m} / \mathrm{s}(70 \mathrm{mph})$ will be approximately 2.8 times the overturning moment due to earthquake loading when $A_{a}=0.4$.

\subsection{Comparison of Base Shear Due to Earthquake and to Wind Loads}

Using the simplified base shear equation

$$
\mathrm{V}=0.5 \mathrm{ZW} \text { or } 0.5 \mathrm{~A}_{\mathrm{a}} \mathrm{W} \quad\left(\mathrm{Z} \text { or } \mathrm{A}_{\mathrm{a}} \geq 0.2\right)
$$

and the same manufactured home dimensions and distribution of dead loads just described, the seismic base shear per unit length of home and the total seismic base shear for a range of values of seismic zone factor $Z$ (or $A_{a}$ in ASCE 7-93) are as listed in Table 11. The length of the manufactured home is assumed to be $21.336 \mathrm{~m}$ (70 ft). Note that the corresponding values of

\begin{tabular}{|c|c|c|c|c|}
\hline \multirow{2}{*}{$\begin{array}{c}\text { Seismic } \\
\text { Zone Factor } \\
\mathrm{Z}\end{array}$} & \multicolumn{2}{|c|}{$\begin{array}{c}\text { Base Shear per Unit } \\
\text { Length of Home }\end{array}$} & \multicolumn{2}{|c|}{ Total Base Shear } \\
\hline & $(\mathrm{N} / \mathrm{m})$ & $(\mathrm{lbf} / \mathrm{ft})$ & $(\mathrm{kN})$ & (lbf) \\
\hline 0.20 & 640 & (44) & 13.70 & $(3,080)$ \\
\hline 0.25 & 805 & (55) & 17.12 & $(3,850)$ \\
\hline 0.30 & 965 & (66) & 20.55 & $(4,620)$ \\
\hline 0.35 & 1,125 & (77) & 23.97 & $(5,390)$ \\
\hline 0.40 & 1,285 & (88) & 27.40 & $(6,160)$ \\
\hline
\end{tabular}
base shear for a double-wide home are approximately twice the values listed in Table 11.

Table 11. Seismic Base Shears for a Single-Wide Manufactured Home Plan dimensions $=4.267 \times 21.336 \mathrm{~m}(14 \times 70 \mathrm{ft})$ 
Factored unit drag loads (horizontal shear per unit length of home) for wind directed normal to the longitudinal axis of a manufactured home are listed in Tables 8 to 10. For wind directed along the longitudinal axis of a single-wide manufactured home the pressure coefficients specified by ASCE 7-93 are $C_{P}=0.80$ for the windward wall and $C_{P}=-0.2$ for the leeward wall. The corresponding values of $C_{P}$ for a double-wide home are 0.80 and -0.275 , respectively. For exposure category $C, K_{h}=0.80$ and $G_{h}=1.32$. Assuming a roof slope of 15 degrees and a net box height of $2.438 \mathrm{~m}(8 \mathrm{ft})$, the nominal drag loads in the longitudinal direction for a basic wind speed of $44.7 \mathrm{~m} / \mathrm{s}(100 \mathrm{mph})$ are as follows:

$$
\mathrm{W}=\mathrm{q}_{\mathrm{h}} \mathrm{G}_{\mathrm{h}} \mathrm{C}_{\mathrm{p}} \mathrm{A}
$$

Dynamic pressure:

$$
\begin{aligned}
\mathrm{q}_{\mathrm{b}} & =(1 / 2) \rho \mathrm{K}_{\mathrm{b}}(\mathrm{IU})^{2} \\
& =(1 / 2)(1.227)(0.80)[(1.0)(44.7)]^{2} \\
& =980.7 \mathrm{~Pa}(20.48 \mathrm{psf})
\end{aligned}
$$

Single-wide unit:

$$
\begin{aligned}
& \text { Width }=4.267 \mathrm{~m}(14 \mathrm{ft}) \\
& \begin{aligned}
\mathrm{A} & =(2.438)(4.267)+(2.134)^{2}(\tan 15) \\
& =11.62 \mathrm{~m}^{2}\left(125 \mathrm{ft}^{2}\right)
\end{aligned} \\
& \begin{aligned}
\mathrm{W} & =(980.7)(1.32)(0.8+0.2)(11.62) \\
& =15.04 \mathrm{kN} \quad(3,380 \mathrm{lbf})
\end{aligned}
\end{aligned}
$$

Double-wide unit:

$$
\begin{aligned}
& \text { Width }=8.535 \mathrm{~m}(28 \mathrm{ft}) \\
& \begin{aligned}
\mathrm{A} & =(2.438)(8.535)+(4.267)^{2}(\tan 15) \\
& =25.69 \mathrm{~m}^{2}\left(277 \mathrm{ft}^{2}\right)
\end{aligned} \\
& \begin{aligned}
\mathrm{W} & =(980.7)(1.32)(0.80+0.275)(25.69) \\
& =35.75 \mathrm{kN} \quad(8,050 \mathrm{lbf})
\end{aligned}
\end{aligned}
$$

To compare the base shears due to wind with the base shears due to earthquake, the nominal drag loads in the longitudinal direction must be multiplied by a load factor of 1.3 since the basis for the earthquake loads specified in ASCE 7-93 is a strength limit state beyond first yield. The factored base shears due to wind loading are listed in Table 12 . 
Table 12. Factored Base Shears Due to Wind Loading

Basic Wind Speed

$(\mathrm{m} / \mathrm{s}) \quad(\mathrm{mph})$
Transverse Base Shear per Unit Length of Home Single- \& Double-Wide
Total Longitudinal Base Shear

Single-Wide

$(\mathrm{kN}) \quad(\mathrm{lbf})$
Double-Wide

$(\mathrm{kN})$

(lbf)

\section{Zone I}

$\begin{array}{rrrrrrrr}31.3 & (70) & 2.6 & (179) & 9.6 & (2,150) & 22.8 & (5,120) \\ 35.8 & (80) & 3.4 & (234) & 12.5 & (2,810) & 29.7 & (6,690) \\ 40.2 & (90) & 4.3 & (296) & 15.8 & (3,560) & 37.6 & (8,460) \\ 44.7 & (100) & 5.3 & (366) & 19.6 & (4,400) & 46.5 & (10,450)\end{array}$

Zone II (Hurricane)
44.7
(100)
5.9
(404)
$21.6 \quad(4,850)$
$51.2(11,520)$

Zone III (Hurricane)

49.2

(110)

$7.1 \quad(488)$

$26.1(5,870)$

$62.0(13,940)$

Comparing the base shears listed in Tables 11 and 12, it is seen that for both single- and doublewide homes the transverse base shear due to wind loading will always be larger than that due to earthquake loading, regardless of the wind zone or seismic zone in which the home is sited. Also, it is likely that the maximum pier forces and overturning moment will be dictated by wind loading even though the resultant of the seismic forces may, for certain situations, act higher on the manufactured home superstructure than does the resultant drag force due to wind.

For base shear in the longitudinal direction, the load ranges for wind and for earthquake are approximately equal. Again, the seismic base shears for double-wide homes will be approximately twice the values listed in Table 11 for single-wide units. In Table 13, the event (wind or earthquake) resulting in the largest longitudinal base shear is listed for single- and double-wide homes sited in the various wind and seismic zones. 
Table 13. Event Producing the Largest Longitudinal Base Shear

Basic Wind Speed

$(\mathrm{m} / \mathrm{s}) \quad(\mathrm{mph})$

0.20

Seismic Zone Factor $\mathrm{Z}$

$\begin{array}{llll}0.25 & 0.30 & 0.35 & 0.40\end{array}$

Single-Wide

Zone I

31.3

(70)

E

E

$\mathrm{E}$

$\mathrm{E}$

35.8

(80)

E

E

E

E

40.2

(90)

W

E

E

E

Zone II (Hurricane)

44.7

(100)

W

W

W

E

E

Zone III (Hurricane)

49.2

(110)

W

W

W

W

E

Double-Wide

Zone I

31.3

E

E

E

E

E

35.8

(80)

W

E

E

E

E

40.2

(90)

W

W

E

E

E

Zone II (Hurricane)

44.7

(100)

W

W

w

W

E

Zone III (Hurricane)

49.2

(110)

W

W

W

W

W

$\mathrm{W}=$ Wind Load

$\mathrm{E}=$ Earthquake Load 
While the previous discussion indicates that seismic loads will only govern in the longitudinal direction when the seismic base shear exceeds the factored wind load, it is important to recognize the fundamental differences between the effects of wind and earthquake loads:

1. Wind loads are imposed on the structural system while earthquake loads are generated by the system. The magnitude of the earthquake loads therefore depends on the characteristics of the structural system. The value of the response modification coefficient assigned by ASCE 7-93 for "light frame walls with shear panels" is $R=6.5$. Implicit in this assigned $R$ value is the assumption that the structure is capable of accommodating inelastic deformations several times greater than the deformation at first yield without failure when subjected to several reverse cycles of earthquake load. Although it is not the purpose of this report to recommend structural design criteria for this condition, it is important to realize that if such criteria are not satisfied, the design earthquake load may have to be increased. The actual earthquake loads would also be greater when the structure is designed for a wind load which substantially exceeds the design earthquake load and, as a result, the structure responds to earthquake loads in a nearly elastic fashion.

2. Under earthquake loading, the structure will be subjected simultaneously to horizontal and vertical accelerations. Thus it is not possible to rely on the gravity forces responsible for the frictional resistance between the manufactured home and the foundation on which it rests. It will therefore be necessary to: a) provide positive (tensile) connections between the main frame and the piers, b) provide some resistance to rotational displacements of the piers in order to prevent loss of support, and c) assure the integrity of supporting piers and their connections to the main frame under the action of net uplift forces.

Thus, even when the wind loads exceed the earthquake loads, special design provisions for the manufactured home itself and for its foundations are needed in areas where values of the seismic zone factor, $\mathrm{Z}$ (or $\mathrm{A}_{2}$ ), are equal to or greater than 0.2 .

\subsection{OVERVIEW OF GENERIC SUPPORT AND ANCHORING SYSTEMS}

\subsection{Traditional Approach}

The traditional approach to providing windstorm protection for manufactured homes consists of helix-plate (auger type) soil anchors and cold-rolled steel strapping installed as diagonal ties between the anchor head and the main frame of the manufactured home. In addition, vertical or "over-the-top" ties may be installed in the case of single-wide units. Vertical support is provided by concrete masonry piers or by prefabricated steel or precast concrete jackstands located under each longitudinal beam of the main frame and spaced longitudinally at $2.44 \mathrm{~m} \mathrm{(8}$ $\mathrm{ft}$ ) or more center-to-center. For convenience, the piers and anchoring components usually are installed after the home is moved into its final position. As a consequence, the soil anchors are installed vertically or even with a slight back-angle just outside the perimeter of the home. Test 
data for this type of installation have been developed by Longinow et al. (1991), and the performance of traditional anchor systems has been reviewed by Marshall (1994). In that review it was shown that the load capacity and stiffness of helix-plate soil anchors generally are far less than what is required to provide adequate resistance (windstorm protection) against the loads acting on diagonal ties and piers as listed in Tables 5 to 7 . Specifically, the problems can be summarized as follows:

- Based on extensive laboratory and field studies, the expectations of MHCSS-94 and of NCSBCS/ANSI A225.1-94 for the performance of traditional anchoring systems far exceed the levels of resistance that these systems can reasonably be expected to provide.

o The large horizontal displacements required to develop acceptable levels of anchor resistance are incompatible with the displacement limits needed to ensure pier stability.

o Because of their shallow depth, stabilizer plates and similar devices exhibit low mean resistance and high variability which makes them minimally effective in increasing the lateral resistance of soil anchors subjected to inclined loads.

- Protective coatings currently used on helix-plate soil anchors are badly damaged or totally removed during anchor installation. In addition, yielding of the anchor shaft and/or damage to the helix-plate to shaft welds have been observed during installation.

It has been shown that in suitable soil conditions the performance of helix-plate soil anchors can

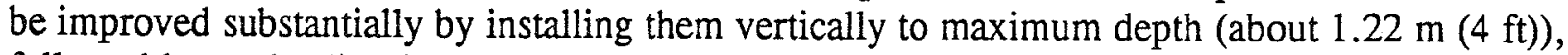
followed by preloading in the direction of the anticipated service load (Yokel et al. 1982). In particular, preloading can produce a significant increase in anchor stiffness, thus eliminating the need for stabilizer plates and similar devices which have been shown to be largely ineffective. The limited test data that are available for cold-rolled steel strapping suggest an in-service ultimate capacity of about $16.9 \mathrm{kN}(3,800 \mathrm{lbf})$. From Table 5, the factored diagonal tie load for a basic wind speed of $44.7 \mathrm{~m} / \mathrm{s}(100 \mathrm{mph})$ is $7.55 \mathrm{kN} / \mathrm{m}(518 \mathrm{lbf} / \mathrm{ft})$, resulting in a maximum anchor spacing of $2.24 \mathrm{~m}(7.3 \mathrm{ft})$. At higher wind speeds the anchor spacing becomes so small that the cones of influence begin to overlap significantly. Therefore, even with preloading, the traditional shallow anchor/tie/pier system is limited in application to basic wind speeds less than about $44.7 \mathrm{~m} / \mathrm{s}$ (100 $\mathrm{mph})$.

\subsection{Arrowhead or Swivel Soil Anchors}

This type of anchor is driven into the supporting soil at the desired angle and depth by a steel driving rod or gad which is positioned over the anchor spindle. Attached to the anchor by a swivel connection is a steel rod or cable which, following removal of the driving rod, is loaded so that the anchor rotates approximately 90 degrees to present maximum bearing surface against withdrawal (see Figure 8). A variation of this anchor type is the pipe or "duckbill" anchor which differs only in the shape of the driven element. Compared with traditional helix-plate soil anchors, arrowhead anchors offer several advantages. First, the anchor can be installed at 
greater depths with minimum soil disturbance and without the problems of anchor shaft yielding or damage to the helix plate or plate-to-shaft welds during installation. Second, the setting of the anchor involves the application of a preload which increases the stiffness of the anchor system and constitutes a proof load or confirmation of anchor capacity. Third, the anchor can be installed so that the critical service load acts coaxially with the attached rod or cable, thus eliminating the need for stabilizer plates or concrete collars often used with traditional helix-plate soil anchors. Fourth, the size and shape of the anchor and depth of installation can be selected to meet the required performance requirements in a given application. Test data for this type of anchor indicate that even for relatively poor soil conditions anchor capacities of 20 to $40 \mathrm{kN}$ (4.5 to 9 kips) can be achieved (Earth-Lok 1994).

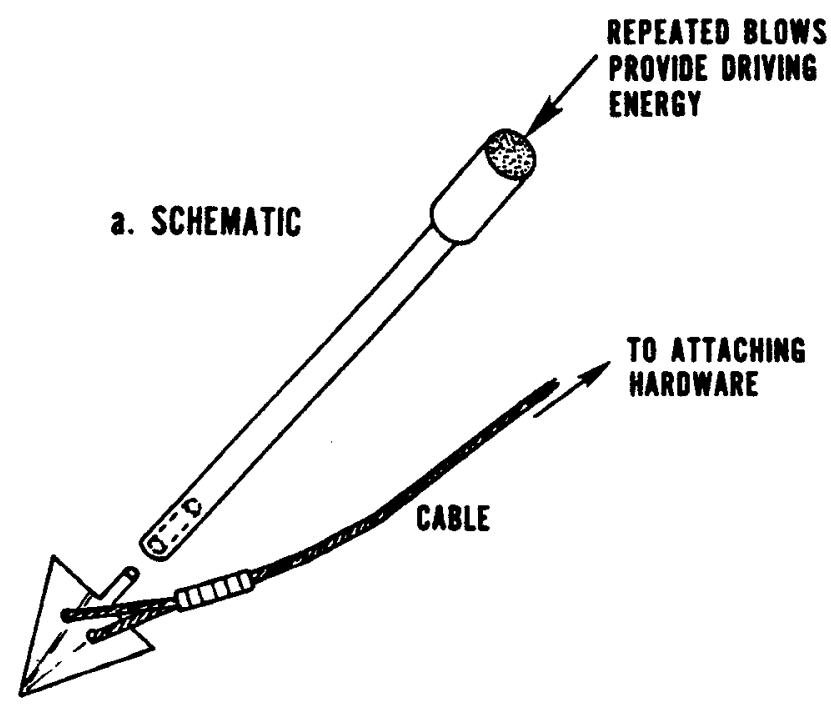

b. IN PLACE

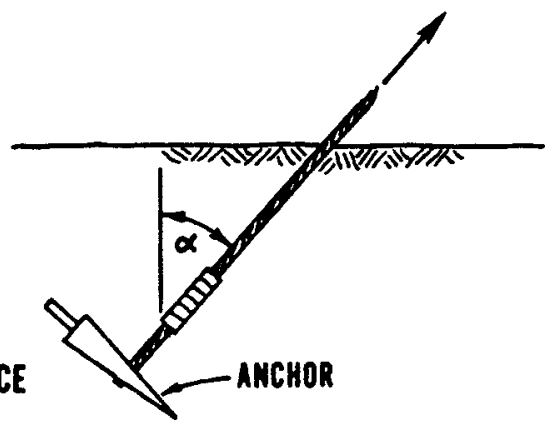

Figure 8. Arrowhead or swivel soil anchor (Kovacs and Yokel 1979)

A tiedown and support system designed for single-wide manufactured homes located in seismic Zone 4 and exposed to a nominal wind speed of $31.3 \mathrm{~m} / \mathrm{s}$ ( $70 \mathrm{mph}$ ) is shown in Figure 9 (EarthLok 1994). The soil anchors are of the arrowhead type attached to threaded steel rods and the piers consist of prefabricated jackstands. In this arrangement the manufactured home is placed in final position on the jackstands, the anchors are then driven from beyond the perimeter of the manufactured home, and the threaded rods are attached to the home at its perimeter by means of suitable connecting fixtures. This anchor and tie arrangement is reasonably simple to install and has obvious advantages when used to retrofit existing homes for increased windstorm protection. However, the arrangement shown in Figure 9 is not particularly efficient for resisting the higher wind loads associated with wind Zones II and III. For example, Table 7 indicates a factored load of $10.07 \mathrm{kN} / \mathrm{m}(690 \mathrm{lbf} / \mathrm{ft})$ for the diagonal frame-tie and windward and leeward pier reactions of $1.03 \mathrm{kN} / \mathrm{m}(71 \mathrm{lbf} / \mathrm{ft})$ and $3.02 \mathrm{kN} / \mathrm{m}(207 \mathrm{lbf} / \mathrm{ft})$, respectively, when using the ASCE 7-93 wind load criteria and the traditional tie and pier arrangement shown in Figure 5. If these same loads are to be resisted by the arrangement shown in Figure 9, it would be necessary to add a row of vertically-oriented anchors and ties along each side of the home, and the corresponding reactions would be as indicated in Figure 10. 


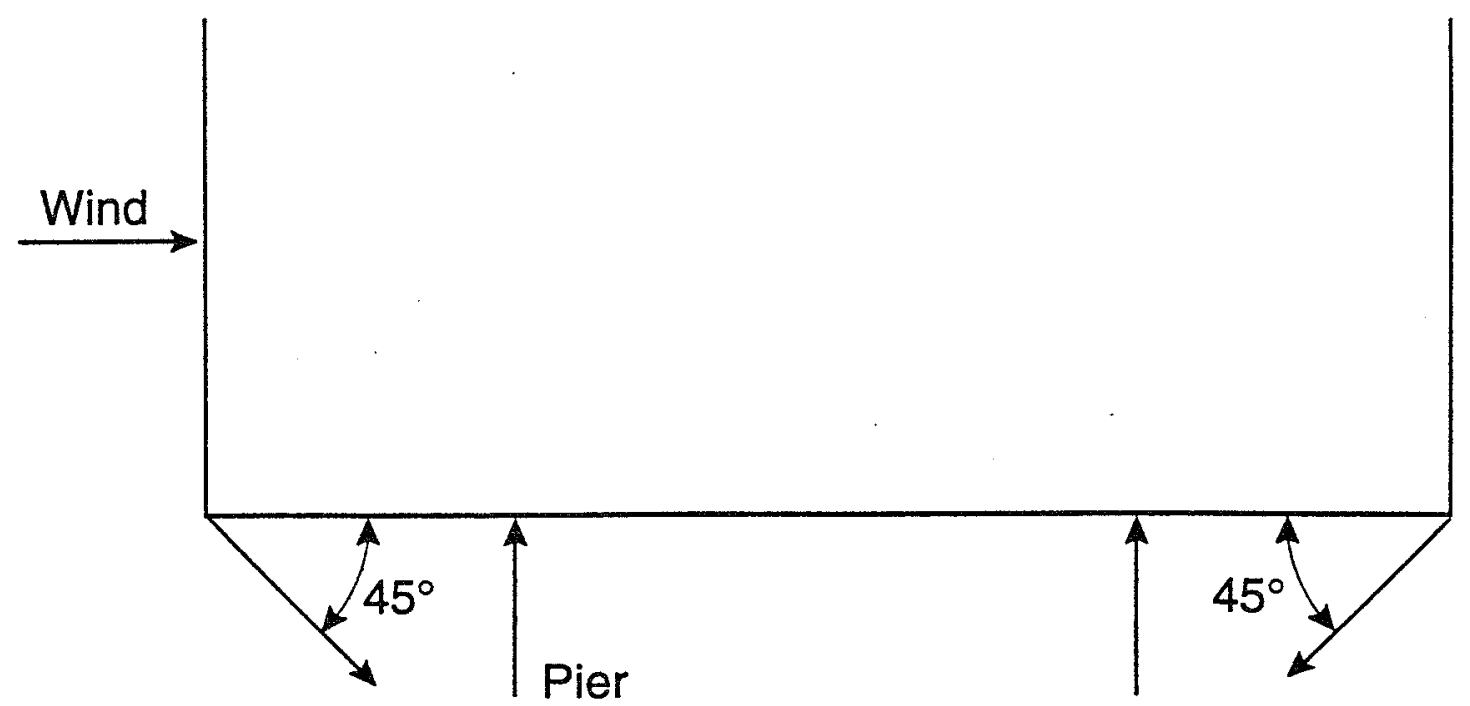

Diagonal Tie

Figure 9. Anchoring scheme employing arrowhead anchors (Earth-Lok 1994)

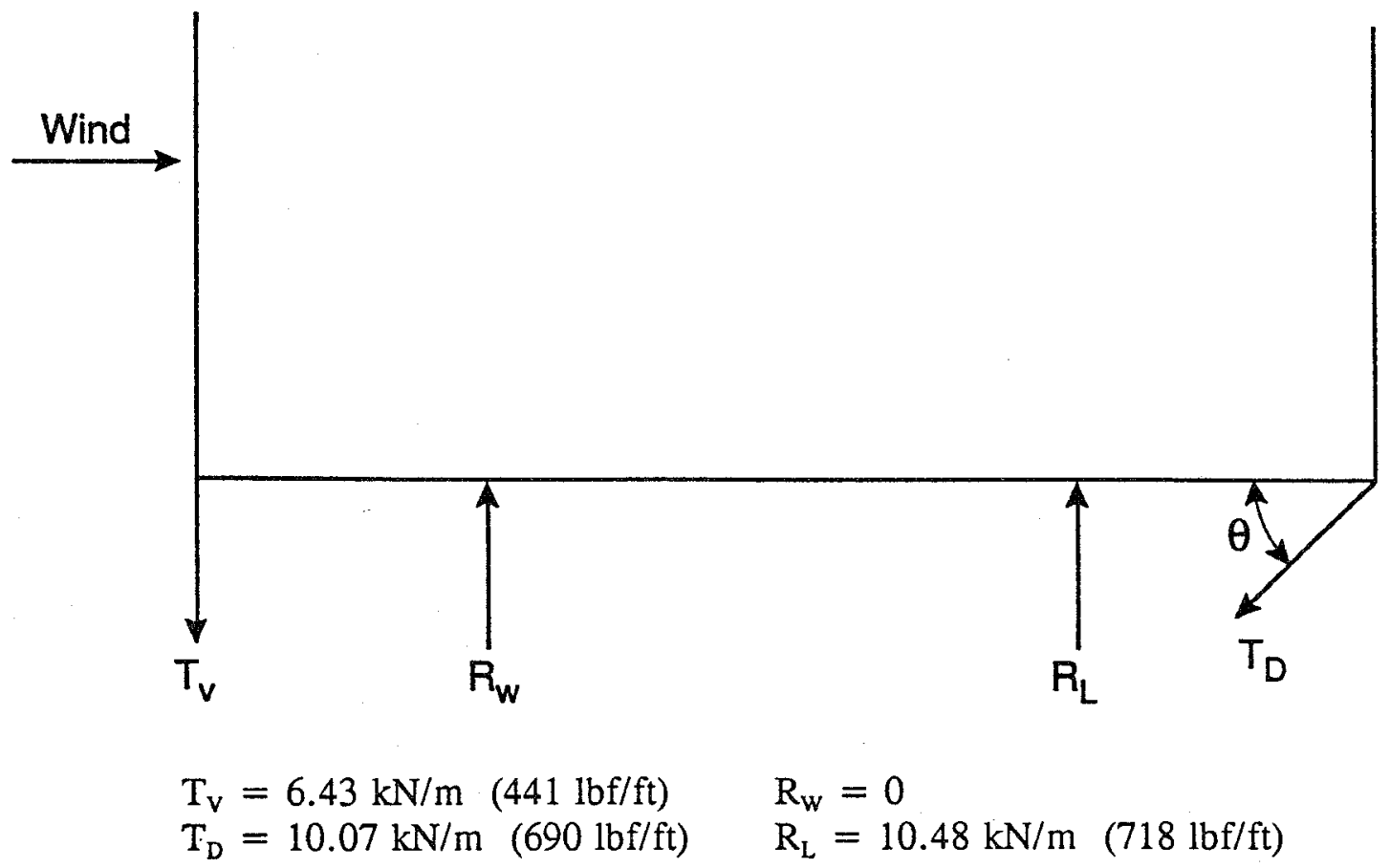

Figure 10. Reactions for a single-wide home in wind Zone III using the anchor arrangement shown in Figure 9 
An improvement to this anchorage system would be the orientation of the anchors and ties as shown in Figure 11, thus avoiding the need for vertical ties and substantially reducing the magnitude of the leeward pier reactions. Note that the leeward pier reaction for the arrangement of Figure 10 is approximately 3.5 times that for the traditional frame-tie and pier arrangement shown in Figure 11. Substitution of flexible steel cable for the rigid threaded steel rods would allow the arrowhead anchors to be driven and preloaded with the orientation indicated in Figure 11 prior to moving the home onto the site. In fact, steel cable appears to have been the preferred tension element when this type of soil anchor was first introduced (Kovacs and Yokel 1979).

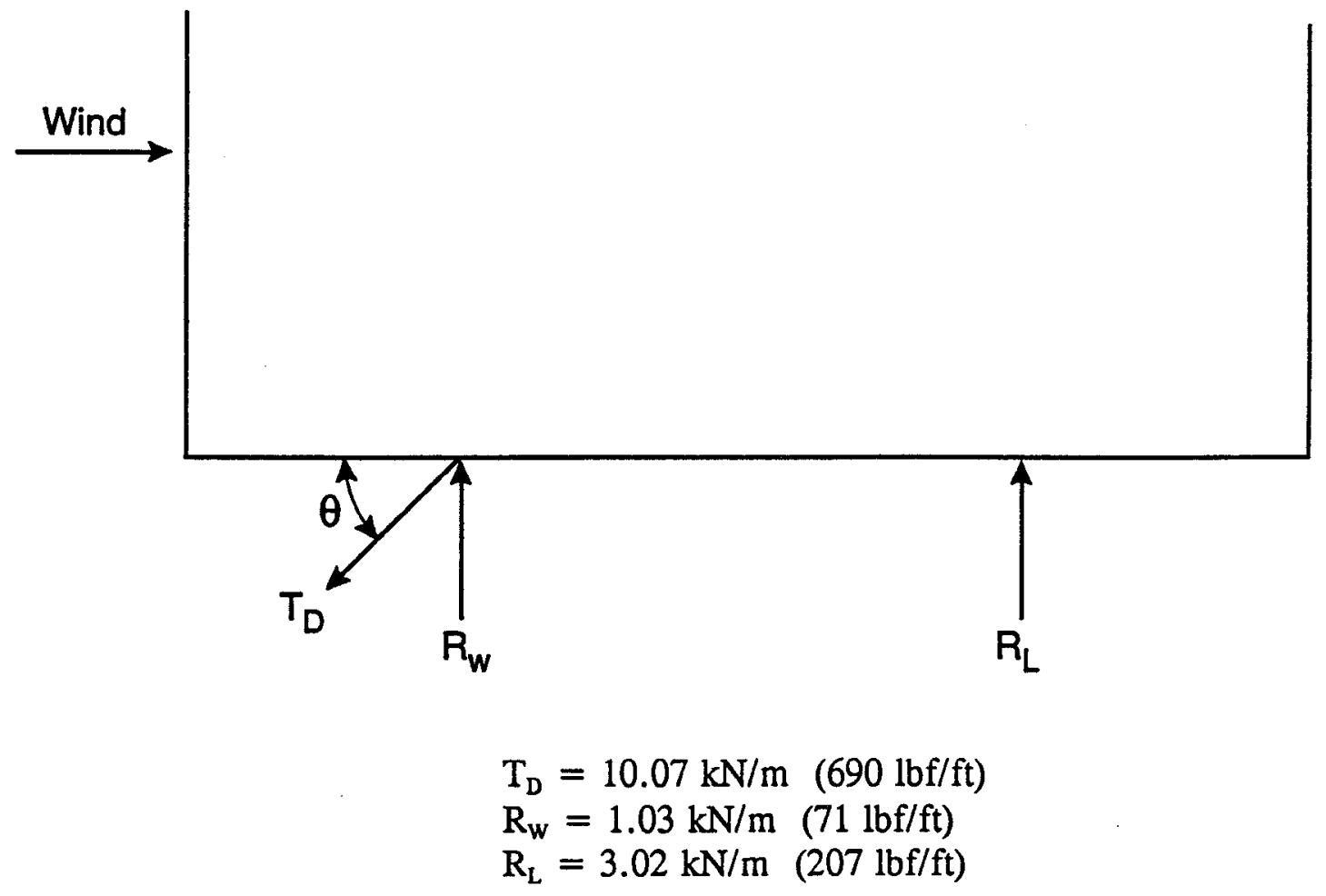

Figure 11. Reactions for a single-wide home in wind Zone III using traditional frame-tie and pier arrangement shown in Figure 5

\subsection{Shallow Piles}

This support scheme, sometimes referred to as a caisson or post and beam foundation, has a number of possible variations including timber, steel or precast concrete piles with or without cross beams. With this system there is no need for footings or soil anchors and strapping, thus largely avoiding the problems associated with frost heave and the need to periodically adjust the anchor-to-frame ties. Another advantage of this system is that each pile resists base shear in any direction whereas only the windward soil anchors are loaded in the traditional anchor/tie/pier 
system. A disadvantage of shallow piles is that placement of the manufactured home can be difficult. However, the use of driven pipe piles with an inner telescoping tube makes the shallow pile a highly workable system (Kovacs and Yokel 1979). Preliminary field tests of such a system have been reported by Hansing (1994). Shallow piles fabricated from steel tube of 102 or $114 \mathrm{~mm}$ (4.0 or $4.5 \mathrm{in.)}$ O.D., $4.8 \mathrm{~mm}$ (3/16 in.) wall thickness, overall length of $1.270 \mathrm{~m}$ (50 in.) and with a capped bottom are driven with a drop hammer so that about $150 \mathrm{~mm}(6 \mathrm{in}$.) of pile protrudes above ground. The piles are driven so as to locate them directly under the longitudinal beams of the manufactured home main frame. A steel tube is then inserted into the driven pile prior to placement of the home, and a pattern of bolt holes in the two tubes allows vertical adjustment with a resolution of $3.2 \mathrm{~mm}(1 / 8 \mathrm{in}$.). Field test results available as of late 1994 (Hansing 1994) can be summarized as indicated in Table 14. In these field tests the top of the driven pile was located $150 \mathrm{~mm}$ (6 in.) above ground, and the telescoping tube was adjusted to a height of $610 \mathrm{~mm}$ (24 in.) above ground as shown in Figure 12. Horizontal loads were applied at the top of the telescoping tube, and loading was discontinued upon reaching an arbitrary lateral displacement of $25 \mathrm{~mm}$ ( 2 in.) at the load point.

From Table 10 (wind Zone III, ASCE 7-93), the resultant horizontal shear is $7.12 \mathrm{kN} / \mathrm{m}$ (488 $\mathrm{lbf} / \mathrm{ft})$ and the windward pier reaction is $-6.08 \mathrm{kN} / \mathrm{m}(-417 \mathrm{lbf} / \mathrm{ft})$ uplift. Assuming the horizontal shear is equally shared by windward and leeward piles, the resultant load on the windward piles is $\left[(3.56)^{2}+(6.08)^{2}\right]^{1 / 2}=7.05 \mathrm{kN} / \mathrm{m}(483 \mathrm{lbf} / \mathrm{ft})$, acting at an angle of 60 degrees with the horizontal. For a longitudinal pile spacing of $3.048 \mathrm{~m}(10 \mathrm{ft})$, the resultant load on a windward pile would be (3.048)(7.05) $=21.49 \mathrm{kN}(4,830 \mathrm{lbf})$ which is consistent with the applied test loads indicated in Table 14 (Inclined Load Tests). Thus, for the soil conditions encountered in these field tests, the shallow pile foundation system would have adequate capacity for applications in wind Zone III. Because wind loading always governs the design for base shear in the transverse direction, and the transverse and longitudinal seismic base shears are essentially equal, the shallow pile system described above should be adequate for use in all seismic zones.

The potential application of this shallow pile system could be enhanced with the availability of data relating load capacity and lateral displacement or stiffness to soil characteristics through a suitable soil classification system or by means of standard test methods such as the SPT or STP. Also, the development of standard frame-to-pier connection details to ensure adequate load transfer and ductility under wind and seismic forces would be desirable. The addition of crossbracing between pairs of piles or a horizontal cross-member with moment connections would increase the transverse load capacity of this system in poor soil conditions. However, these features may not prove to be cost effective. 


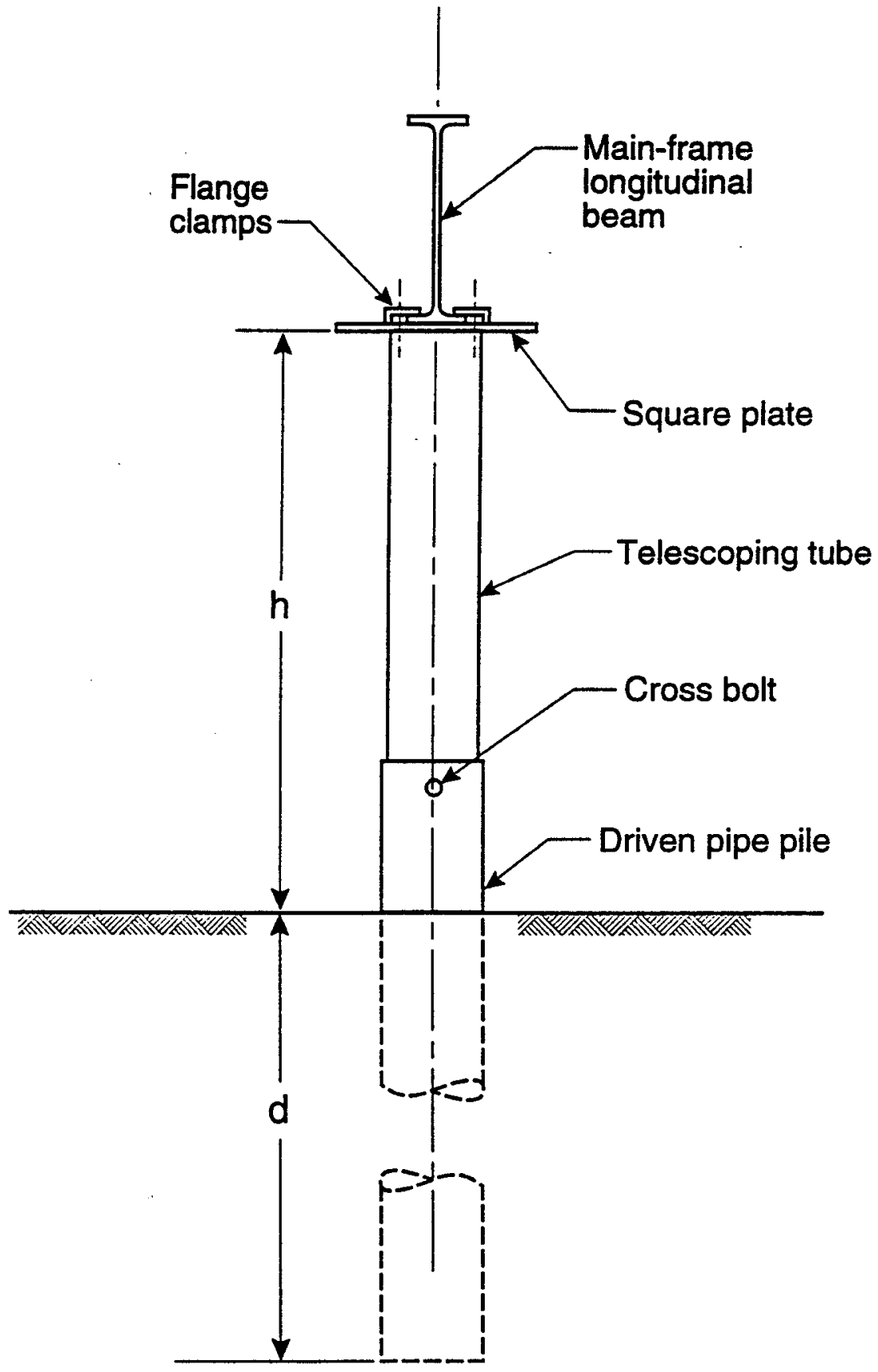

Figure 12. Shallow pipe pile with telescoping insert (Hansing 1994) 
Table 14. Field Test Results for Shallow Piles (Hansing 1994)

Pipe Pile O.D.

Average Maximum Applied Load

$(\mathrm{mm})$

(in)

$(\mathrm{kN})$
Lat. Displacement

Top of Inner Tube

(mm)

(in)
Lat. Displacement

Top of Pipe Pile

(mm) (in)

Lateral Load Tests:

$\begin{array}{llllllll}102 & (4.0) & 14.2 & (3,200) & 50.8 & (2.00) & 22.7 & (0.90) \\ 114 & (4.5) & 16.7 & (3,750) & 52.4 & (2.06) & 27.8 & (1.09)\end{array}$

Inclined Load Tests:

(Applied at 60 degrees to horizontal)
102
$(4.0)$
21.6
$(4,870)$
$40.2 \quad(1.58)$
26.5
(1.04)

Vertical Withdrawal:

$\begin{array}{llll}102 & (4.0) & 16.4 & (3,680) \\ 114 & (4.5) & 14.5 & (3,260)\end{array}$

\subsection{Concrete Slab on Grade}

A concrete slab on grade, also referred to as a "floating slab system," has the advantage of not requiring soil anchors or individual footings for the supporting piers. The basic requirements for such a system have been described by Kovacs and Yokel (1979). These requirements include sufficient dead load to resist overturning and sliding with a factor of safety of approximately 1.5, and adequate moment and shear capacity to resist failure under the forces exerted by the ties, by the supporting piers, and by frost heave or expansive soils. In addition, the concrete must be capable of resisting weathering effects such as those associated with freeze/thaw cycles. Typically, these slabs extend to or beyond the perimeter of the manufactured home, range in thickness from 100 to $150 \mathrm{~mm}$ (4 to $6 \mathrm{in}$.), and are reinforced with welded wire fabric. Connections for the ties can be cast into the slab or may be installed in finished slabs by drilling holes for thru-bolts or for commercially available expanding inserts. Connection patterns can be developed to accommodate various sizes of homes and various tie spacings. Either full slabs or strip slabs may be used as indicated in Figure 13, provided the resistance is sufficient to resist the overturning and sliding forces with a suitable factor of safety. In the proportioning of slabon-grade foundations, UBC-94 specifies a minimum thickness of $102 \mathrm{~mm}$ (4 in.) and slab reinforcing that depends on a climate factor, the soil plasticity index, and the yield strength of the reinforcing steel. Approximately, the product $A_{s} f_{y}$ can range from 38 to $77 \mathrm{kN} / \mathrm{m}$ where $A_{s}$ is the area of the reinforcing steel per unit width of slab in $\mathrm{mm}^{2} / \mathrm{m}$ and $\mathrm{f}_{\mathrm{y}}$ is the yield strength 
of the reinforcing steel in $\mathrm{MPa}\left(2,600\right.$ to $5,300 \mathrm{lbf} / \mathrm{ft}$ where $\mathrm{A}_{\mathrm{s}}$ is expressed $\mathrm{in}^{2} / \mathrm{ft}$ and $\mathrm{f}_{\mathrm{y}}$ is expressed in psi).

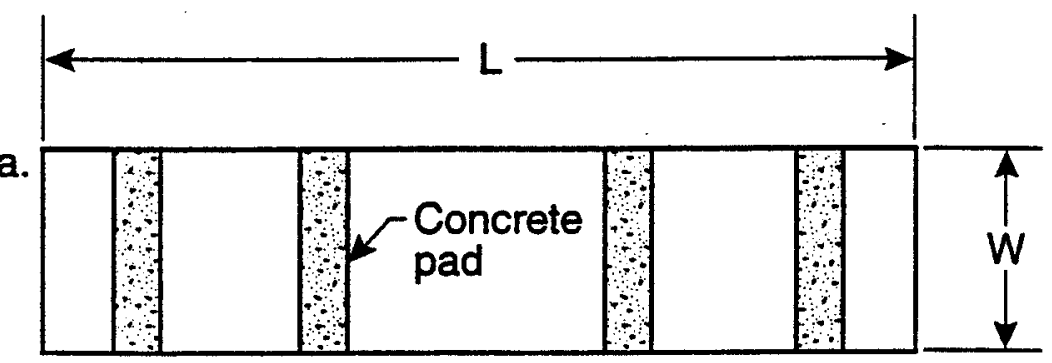

b.

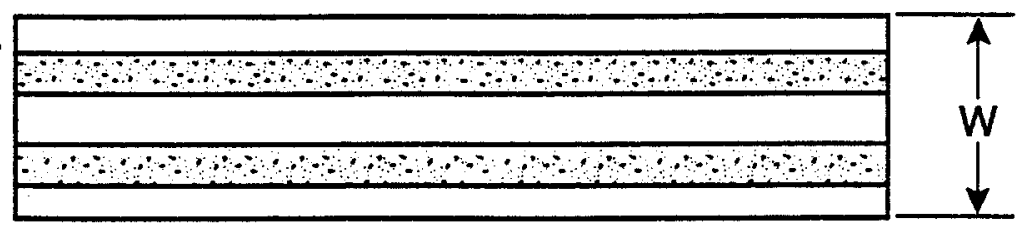

c.

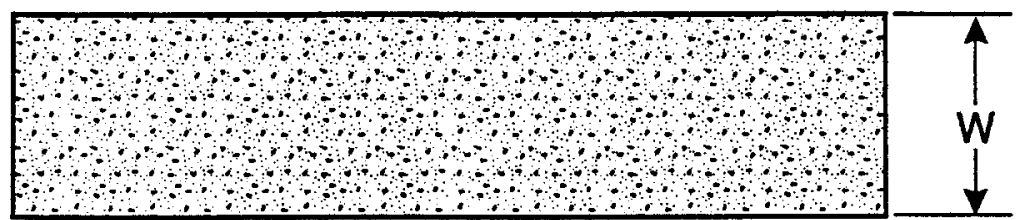

Concrete

Figure 13. Concrete Slab on Grade (Kovacs and Yokel 1979) 


\subsection{Portable Precast Concrete Piers}

Another alternative to traditional windstorm protection is the use of portable precast concrete piers as indicated in Figure 14. The advantage of this system is that soil conditions, other than limitations on settlement, are not critical since the system depends upon the dead load of the piers for stability. A major disadvantage of this system is that the piers must be inserted under the manufactured home after its placement on the site, an operation that would require power equipment such as a forklift. Not shown in Figure 14 are the mechanical connections between the piers and the manufactured home main-frame. In addition to accommodating the base shear and vertical reactions, these mechanical connections must provide for sufficient vertical adjustment to level the home on its piers.

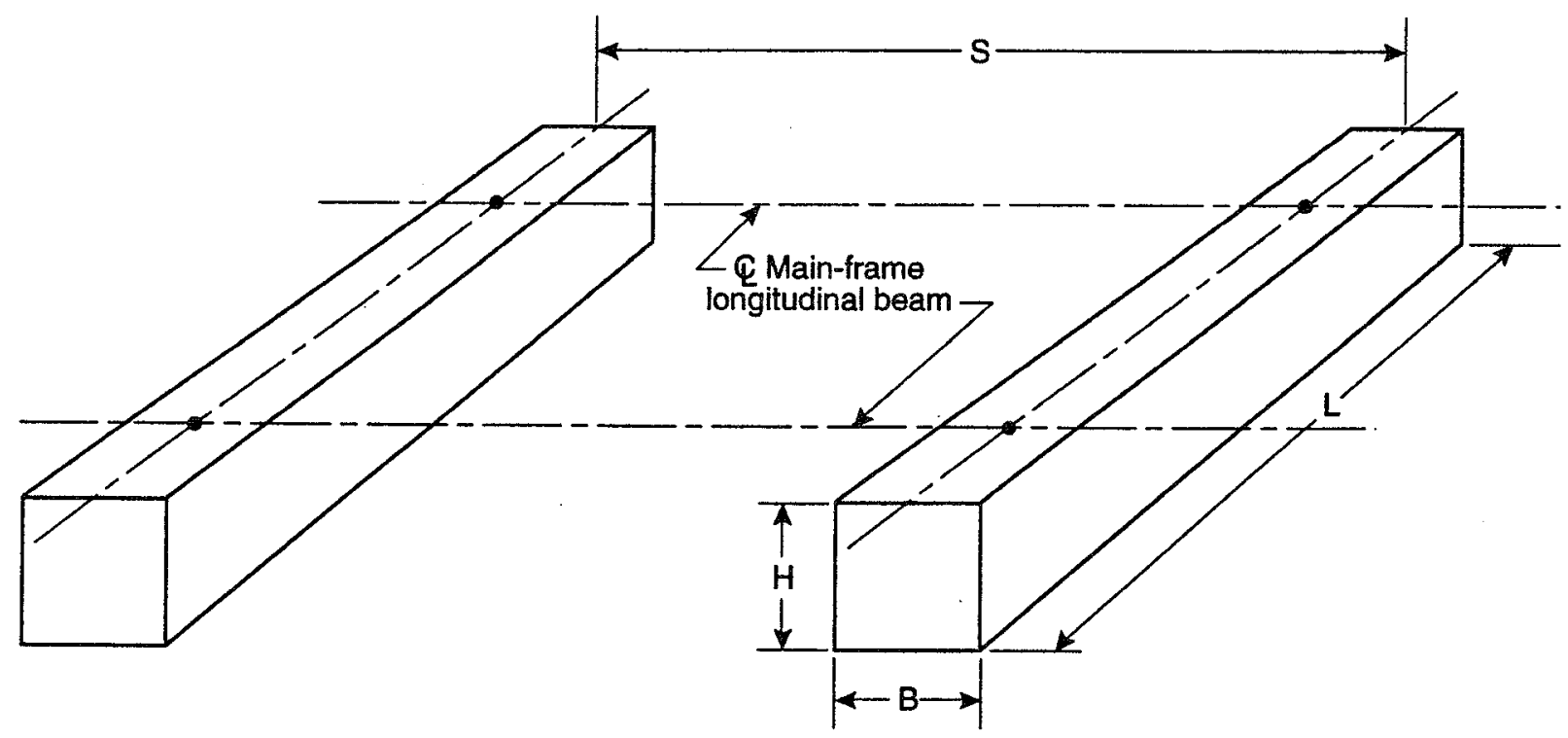

Figure 14. Portable Precast Concrete Piers

Maximum pier spacing, S, suggested by NCSBCS/ANSI A225.1-94 is $2.438 \mathrm{~m}(8 \mathrm{ft})$. Presumably, this spacing is dictated more by the requirement for floor stiffness than by any load limitations. If this spacing is assumed to apply, then it is possible to determine the required mass of the precast piers based on the main-frame reactions listed in Tables 8 to 10 for factored loads. In obtaining the following pier dimensions, it was assumed that the clearance between

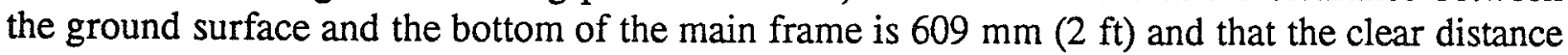
between the top of the pier and the bottom of the main frame is $152 \mathrm{~mm} \mathrm{(6} \mathrm{in.),} \mathrm{resulting} \mathrm{in} \mathrm{a}$ net pier height, $\mathrm{H}$, of $457 \mathrm{~mm}$ (18 in.) in each case. It was further assumed that the coefficient of friction between the pier and the soil is 0.8 . The length, $\mathrm{L}$, of the precast piers was assumed to be $3.048 \mathrm{~m}(10 \mathrm{ft})$, and the unit weight of concrete was taken to be $2,403 \mathrm{~kg} / \mathrm{m}^{3}\left(150 \mathrm{lbm} / \mathrm{ft}^{3}\right)$. 
Required Pier Dimensions for Stability Against Wind Loading:

\section{Wind Zone I}

$\mathrm{U}=31.3 \mathrm{~m} / \mathrm{s} \quad(70 \mathrm{mph})$

Mass required for stability against sliding $=369 \mathrm{~kg}(814 \mathrm{lbm})$

Mass required for stability against overturning $=396 \mathrm{~kg}(874 \mathrm{lbm})$

Cross-sectional area $=0.054 \mathrm{~m}^{2}\left(0.58 \mathrm{ft}^{2}\right)$

Height $=457 \mathrm{~mm}(1.50 \mathrm{ft})$

Width $=118 \mathrm{~mm}(0.39 \mathrm{ft})$

Assume minimum pier width $=305 \mathrm{~mm}(1 \mathrm{ft})$

$\mathrm{U}=40.2 \mathrm{~m} / \mathrm{s}$ (90 mph)

Mass required for stability against sliding $=1,354 \mathrm{~kg}(2,984 \mathrm{lbm})$

Mass required for stability against overturning $=1,403 \mathrm{~kg}(3,094 \mathrm{lbm})$

Cross-sectional area $=0.192 \mathrm{~m}^{2}\left(2.06 \mathrm{ft}^{2}\right)$

Height $=457 \mathrm{~mm}(1.50 \mathrm{ft})$

Width $=419 \mathrm{~mm}(1.38 \mathrm{ft})$

Wind Zone II (Hurricane)

$\mathrm{U}=44.7 \mathrm{~m} / \mathrm{s} \quad(100 \mathrm{mph})$

Mass required for stability against sliding $=2,264 \mathrm{~kg}(4,992 \mathrm{lbm})$

Mass required for stability against overturning $=2,332 \mathrm{~kg}(5,140 \mathrm{lbm})$

Cross-sectional area $=0.318 \mathrm{~m}^{2}\left(3.43 \mathrm{ft}^{2}\right)$

Height $=457 \mathrm{~mm}(1.50 \mathrm{ft})$

Width $=696 \mathrm{~mm}(2.28 \mathrm{ft})$

\section{Wind Zone III (Hurricane)}

$\mathrm{U}=49.2 \mathrm{~m} / \mathrm{s} \quad(110 \mathrm{mph})$

Mass required for stability against sliding $=2,976 \mathrm{~kg}(6,560 \mathrm{lbm})$

Mass required for stability against overturning $=3,055 \mathrm{~kg}(6,736 \mathrm{lbm})$

Cross-sectional area $=0.417 \mathrm{~m}^{2}\left(4.49 \mathrm{ft}^{2}\right)$

Height $=457 \mathrm{~mm}(1.50 \mathrm{ft})$

Width $=913 \mathrm{~mm}(3.00 \mathrm{ft})$

Table 15 provides a comparison of concrete quantities for a slab on grade system and for portable precast piers for the case of a manufactured home with dimensions $4.2675 \times 24.384 \mathrm{~m}$ $(14 \times 80 \mathrm{ft})$ and pier spacing of $2.44 \mathrm{~m}(8 \mathrm{ft})$ center-to-center. 
Table 15. Comparison of Concrete Quantities: Slab on Grade vs. Precast Piers

\begin{tabular}{|c|c|c|c|c|c|}
\hline \multirow{2}{*}{$\begin{array}{l}\text { Foundation System } \\
\text { Slab on Grade }\end{array}$} & $\begin{array}{l}\text { Slab Thickness } \\
\begin{array}{ll}(\mathrm{mm}) \quad \text { (in.) }\end{array}\end{array}$ & \multicolumn{2}{|c|}{$\begin{array}{l}\text { Design Wind Speed } \\
(\mathrm{m} / \mathrm{s}) \quad(\mathrm{mph})\end{array}$} & \multicolumn{2}{|c|}{$\begin{array}{l}\text { Concrete Volume } \\
\left(\mathrm{m}^{3}\right) \quad(\mathrm{Cu} \text {. Yds. })\end{array}$} \\
\hline & 102 & & & 10.57 & (13.83) \\
\hline & 152 & & & 15.86 & (20.74) \\
\hline \multirow[t]{4}{*}{ Precast Piers } & & 31.3 & (70) & 4.67 & $(6.11)$ \\
\hline & & 40.2 & (90) & 6.42 & $(8.40)$ \\
\hline & & 44.7 & $(100)$ & 10.67 & (13.96) \\
\hline & & 49.2 & (110) & 13.99 & $(18.30)$ \\
\hline
\end{tabular}

From Table 15 it can be seen that in terms of material required, portable precast concrete piers are more efficient than a slab on grade for design wind speeds of up to $40.2 \mathrm{~m} / \mathrm{s}(90 \mathrm{mph})$. At higher wind speeds a slab on grade probably would prove to be more cost effective.

With regard to soil bearing pressures, NCSBCS A225.1 gives design loads (live plus dead plus snow) for three zones as follows:

$\begin{array}{lll}\text { South Zone } & 3.59 \mathrm{kPa} & (75 \mathrm{psf}) \\ \text { Middle Zone } & 4.07 & (85) \\ \text { North Zone } & 4.55 & (95)\end{array}$

For the North Zone and a minimum pier width of $305 \mathrm{~mm}(1 \mathrm{ft})$, the corresponding soil pressure is approximately $61.7 \mathrm{kPa}(1,290 \mathrm{psf})$. This is only slightly greater than the minimum allowable soil pressure considered by NCSBCS/ANSI A225.1-94 for unclassified soils, $47.9 \mathrm{kPa}(1,000$ psf). Therefore, allowable bearing pressure should not pose a problem when using precast piers of the dimensions indicated above.

The analysis described above is based on an assumed coefficient of friction of 0.8 for concrete on soil. While this may be a reasonable assumption for wind loading, such a high value cannot be relied upon to resist earthquake forces because of the simultaneous horizontal and vertical accelerations which act on the manufactured home and its supports. Precast concrete piers without some provision for positive soil anchorage are not recommended for seismic zones where $\mathrm{A}_{\mathrm{a}}$ or $\mathrm{Z} \geq 0.2$. 


\subsection{Permanent Foundations}

This category of foundation system is sometimes referred to as a load-bearing perimeter foundation. A number of schemes have been used successfully, and a detailed description of selected systems can be found in the publication Permanent Foundations Guide for Manufactured Housing (HUD. 1989). Three basic foundation types and six alternate types are described in detail, along with recommended design procedures. Design loads (wind, snow and earthquake) used in this document are obtained from ANSI A58.1-1982 (now ASCE 7) Minimum Design Loads for Buildings and Other Structures. This guide is undergoing revision and is to be reissued in 1995. Generally, the design and installation of permanent foundations are subject to local building codes and regulations. A major advantage of the permanent foundation system is that the need for traditional soil anchors and ties is dispensed with. Also, because the shear and overturning moment due to wind loading are resisted by reactions distributed over the length of the home and acting at the sidewalls, the maximum vertical reactions under wind loading are substantially reduced in comparison with vertical reactions acting at the longitudinal beams of the main frame. The major disadvantage is a generally higher cost of installation.

A recent development under the category of permanent foundations involves the use of steel tripods or stanchions supported by and attached to conventional cast-in-place concrete piers or footings (Tucker 1994). The advantages of this system are that the home can be positioned without the hinderance of protruding piers or perimeter walls; the stanchions provide a positive ductile (bolted) connection at both the manufactured home main frame and footing; and stanchion height can be selected in four ranges from 255 to $760 \mathrm{~mm}$ (10 to 30 in.) with continuous adjustment over a range of $130 \mathrm{~mm}$ ( $5 \mathrm{in}$.) by means of a threaded steel rod.

\subsection{PERFORMANCE-BASED CRITERIA FOR MANUFACTURED HOME SUPPORT AND ANCHORING SYSTEMS}

A summary of selected requirements for manufactured home support and windstorm protection is presented in Appendix $\mathrm{C}$ of this report. The State requirements described therein do not reflect the changes to the MHCSS for hurricane zones issued by HUD in 1994 or the current requirements of NCSBCS/ANSI A225.1-94 for wind Zones II and III. However, the rules issued by the State of California appear to reflect recent experience gained from the Northridge Earthquake of January 17, 1994.

As noted in Section 5.1 of this report, the expectations of MHCSS-94 and of NCSBCS/ANSI A225.1-94 for traditional anchoring systems far exceed the levels of resistance that these systems can reasonably be expected to provide. Furthermore, the various provisions for manufactured home support and anchoring provisions summarized in Appendix $\mathrm{C}$ represent, at best, a disjointed mix of prescriptive and performance-based criteria that have the potential for excluding certain innovative systems that could be expected to perform adequately. Based on the findings reported herein, the following performance-based criteria are recommended for the design and installation of manufactured home support and anchoring systems to resist both wind and earthquake loads: 


\subsection{Allowable Soil Bearing Pressures}

In firm, dry or unsaturated soils the allowable bearing pressures shall not exceed $95 \mathrm{kPa}(2 \mathrm{ksf})$ under the effect of dead and live loads, or $145 \mathrm{kPa}(3 \mathrm{ksf})$ when these loads are combined with wind or earthquake effects. In saturated, submerged, or soft soils the corresponding allowable bearing pressures shall be $48 \mathrm{kPa}(1 \mathrm{ksf})$ and $72 \mathrm{kPa}(1.5 \mathrm{ksf})$, respectively. These allowable pressures may be exceeded if the bearing capacity of the soil is evaluated by a geotechnical engineer.

\subsection{Horizontal Load Effects}

Horizontal load effects can be resisted by soil anchors or by other foundation elements. Anchor ties or straps shall be attached to the top of the longitudinal beams of the main frame. When soil anchors are used they shall be preloaded ${ }^{1}$ in the direction of the tie(s) or strap(s) connecting the anchor to the manufactured home. The preload shall not be less than the calculated effect of the factored loads. A capacity reduction factor of 1 can be assumed for preloaded anchors.

\subsection{Allowable Horizontal Displacements}

Allowable horizontal displacements at the top of the supporting piers shall not exceed $1 / 4$ of the width of the top of the supporting piers or 50 percent of the displacement which would cause rupture of gas lines. When preloaded soil anchors are used, this criterion is deemed to be satisfied.

\subsection{Frictional Resistance}

The frictional force between foundation elements and the supporting soil shall not exceed 50 percent of the calculated minimum vertical load effects on these foundation elements. If horizontal loads are resisted by frictional forces between the main frame and the piers, full contact between the main frame and the supporting piers must be assured by appropriate installation procedures, and the frictional force at the top of the foundation piers shall not exceed 30 percent of the calculated minimum vertical load effect on these piers.

\subsection{Durability of Foundation Elements}

Foundation elements shall be designed to remain serviceable for the expected service life of the manufactured home. Soil anchors and their connecting devices, as well as other corrodible foundation elements, shall be galvanized and their durability shall not be impaired by installation procedures. Foundation elements made of wood shall be appropriately pressure treated and protected against termites, and concrete slabs on grade shall be constructed on compacted

1 The preload shall be maintained for a least two minutes without causing load relaxation by displacement of the anchor head. The preload shall then be removed. 
granular subgrades with good quality concrete and reinforced to prevent their disintegration by shrinkage, temperature changes, or soil displacement effects.

\subsection{Permanent Foundations}

When permanent foundations are used to support manufactured homes the foundations shall be constructed in compliance with the applicable building code(s) or accepted foundation design guides.

\subsection{Earthquake Effects}

Earthquake effects can be resisted by appropriately designed foundation support systems or, alternatively, by secondary support systems ${ }^{2}$ which are designed to prevent excessive damage to the manufactured home in case of failure of the primary load-supporting foundation system.

\subsubsection{Earthquake Resistant Foundation Support Systems}

In earthquake zones where $A_{a}$ or $Z \geq 0.2$ there shall be ductile connections such as steel anchor bolts or connections of similar ductility between the manufactured home and the supporting piers, capable of resisting a tensile force equal to 1.5 times the dead load of the supporting pier but not less than 50 percent of the vertical reaction force acting on the pier. Concrete block piers shall be reinforced and grouted. When horizontal load resistance is provided by the supporting piers, the piers or their connection to the manufactured home main frame shall be designed to resist rotational effects caused by the horizontal load applied at the top of the piers. If a peripheral supporting skirt is used as a foundation, it will be necessary, in addition to the connections between the skirt and the manufactured home, to ensure by appropriate lateral bracing that the supporting skirt can resist rotational effects caused by the lateral load acting at its top.

\subsubsection{Earthquake Resistant Secondary Support Systems}

Secondary support systems shall be designed to prevent a vertical drop of the manufactured home in excess of $25 \mathrm{~mm}(1 \mathrm{in}$.) or any displacement of the manufactured home in excess of 50 percent of the displacement which would cause rupture of gas lines or major structural damage as a result of failure of the primary foundation support system. Secondary support systems and their connections to the manufactured home shall be designed to resist rotational effects caused by horizontal earthquake forces during or following failure of the primary foundation support system.

2 Secondary support systems may be installed under existing manufactured homes as a retrofit measure. 


\subsection{Commentary}

\subsubsection{General}

Criteria (6.1) through (6.6) apply to all manufactured home installations. Criteria (6.7) apply to the seismic zones specified.

\section{C6.1 Allowable Soil Bearing Pressures}

Because of the relatively low dead load of manufactured homes, allowable soil bearing pressures will seldom be critical. Unless accurate data are available, the dead load of manufactured homes should be assumed to be $1.20 \mathrm{kPa}$ ( $25 \mathrm{psf}$ ), and the live load should be assumed to be $1.92 \mathrm{kPa}$ (40 psf) when bearing pressures are calculated.

\section{C6.2 Horizontal Load Effects}

It is recommended that anchor ties be connected to the top of the main-frame longitudinal beams to prevent their failure by torsional deformation. The beneficial effect of preloading soil anchors has been documented by Yokel et al. (1982). Numerous test results (Yokel et al. 1982, Longinow et al. 1991) indicate that the load capacity of traditional helix-plate soil anchors is substantially less than that required by the applicable standards. Furthermore, the lateral stiffness (load-displacement ratio) of these anchors is inadequate, even when stabilizing devices such as steel plates or concrete collars are used. Preloading will not only increase the stiffness of soil anchors by a factor of five or more, but preloading also constitutes a proof test which will assure the adequacy of their load resistance. For this reason there is no need to apply a capacity reduction factor when preloaded soil anchors are used. The need for preloading of soil anchors has been further documented by Marshall (1994). Factored loads for diagonal frame-ties and for single-wide home pier reactions are given in Tables 5-7 of this report. Corresponding main-frame reactions are given in Tables 8-10. Factored base shears due to wind loading in the transverse and longitudinal directions are listed in Table 12.

\section{C6.3 Allowable Horizontal Displacements}

The purpose of this criterion is to prevent failures caused by sliding from, or excessive rotation of, foundation piers. The criterion also is intended to prevent loss of life and property damage caused by gas line ruptures and subsequent gas ignition.

\section{C6.4 Frictional Resistance}

For the purpose of calculating frictional resistance, live loads should be assumed to be zero, and uplift as well as overturning forces must be taken into consideration. 


\section{C6.5 Durability of Foundation Elements}

Field studies carried out by Yokel et al. (1972) showed that severe damage or total removal of the protective coating occurred during the installation of traditional helix-plate soil anchors. If concrete slabs on grade are used, they should be at least $100 \mathrm{~mm}(4 \mathrm{in}$.) thick and should be constructed on a base of compacted gravel at least $150 \mathrm{~mm}(6 \mathrm{in}$.) thick. Concrete slabs should be constructed of concrete with a 28-day compressive strength of not less than $20.7 \mathrm{MPa}(3,000$ psi) and should be reinforced in both directions against temperature and shrinkage effects.

\section{C6.6 Permanent Foundations}

Recommended details for permanent (conventional) foundations can be found in HUD Handbook 4930.3, Permanent Foundations Guide for Manufactured Housing. The contents of this document have been summarized in Section 5.6 of this report.

\section{C6.7 Earthquake Effects}

Secondary support systems or earthquake resistant bracing systems (ERBS) are commonly used in California. It may be practical to install such systems as a retrofit measure for existing manufactured homes. Seismic base shears for single-wide homes are listed in Table 11 of this report. The corresponding base shears for double-wide units may assumed to be twice the values listed in Table 11.

\section{C6.7.1 Earthquake Resistant Foundation Support Systems}

In an earthquake the manufactured home and its foundation support system will be subjected simultaneously to horizontal and vertical accelerations. Thus, it is not possible to rely on the gravity forces responsible for the contact, and possibly the frictional forces, between the manufactured home and the foundation system. It is therefore necessary to: 1) provide ductile positive (tensile) connections between the main frame and the piers, and 2) provide resistance to rotational displacements of the piers in order to prevent jackknifing of the piers. Rotational displacement of the piers can be prevented by horizontal bracing between piers or, alternatively, by appropriate moment resisting connections between the piers and the manufactured home.

\section{C6.7.2 Earthquake Resistant Secondary Support Systems}

Since secondary support systems are designed to "catch" the manufactured home after is slips off its primary foundation, it is important to ensure that the resultant displacements do not cause rupture of gas lines. It also has been observed in the Northridge earthquake (NCSBCS 1994) that many secondary support systems jackknifed or otherwise failed under the prevailing horizontal loads. 


\subsection{MAJOR FINDINGS AND RECOMMENDATIONS}

\subsection{General}

Wind and earthquake forces affecting the design of support and anchoring systems for manufactured homes are examined in this report. Included in the assessment of wind loads is the issue of tornadoes as a basis for the development of windstorm protection criteria. Anchorage requirements for wind and earthquake forces acting in the transverse and longitudinal directions are compared, and a simplified seismic base shear equation for manufactured homes is proposed.

An overview of generic support and anchoring systems is presented, and certain innovative systems are described that offer attractive alternatives to the traditional shallow soilanchor/tie/pier approach using helix-plate soil anchors and steel strapping. Current prescriptive requirements for the design and installation of windstorm protection systems are reviewed and compared. A set of performance-based criteria for the design of manufactured home support and anchoring systems is proposed which provides for both wind and earthquake loading.

\subsection{Major Findings}

The major findings resulting from this study can be summarized as follows:

- Even for the most severe tornado wind region, extreme wind speeds due to tornadoes are less than extreme speeds due to other wind phenomena for point targets and annual probabilities of exceedance greater than about $3 \times 10^{-4}$.

o Assuming the structural system is properly detailed to resist earthquake forces, the transverse base shear for either single- or double-wide manufactured homes subjected to wind loading will always be larger than that due to earthquake loading, regardless of the wind or seismic zone in which the manufactured home is sited.

o For base shear in the longitudinal direction, the load ranges for wind and for earthquake are approximately equal and, therefore, each must be checked to determine the governing event (wind or earthquake):

- The magnitude of earthquake forces is highly dependent upon the characteristics of the structural system. Implicit in the determination of these forces is the ability of the structure to accommodate inelastic deformations several times greater than the deformation at first yield.

- Ductile connections between the supporting piers and the manufactured home are essential in seismic zones where $A_{a}$ or $Z \geq 0.2$. 
o The performance of the traditional shallow soil-anchor/tie/pier system can be improved with preloading. However, this system appears to be limited to applications where the basic wind speed is less than $44.7 \mathrm{~m} / \mathrm{s}(100 \mathrm{mph})$.

- There are several innovative foundation/anchoring systems available or under development that indicate considerable improvement over the traditional shallow anchor/tie/pier system in common use today.

- Current requirements (Federal, State or local) for windstorm protection employ a mixed format of prescriptive and performance-based criteria which tend to exclude or inhibit the development and application of innovative anchorage and support systems that could be expected to perform adequately.

\subsection{Recommendations}

The following recommendations are made on the basis of the findings summarized above:

- Given the accepted risk of attaining or exceeding design limit states for ordinary buildings, tornadoes should not be considered in the development of wind load criteria for the design of manufactured homes. These criteria should be consistent with the requirements of ASCE 7-93, Minimum Design Loads for Buildings and Other Structures.

- Tornadoes constitute a significant hazard to human life, and tornado shelters should be an integral part of manufactured home parks.

- Loads for the design of transverse tiedown systems should be based on the factored transverse shear (drag load) due to wind loading, regardless of the seismic zone in which a manufactured home is sited.

o Both wind and earthquake loads must be considered in the design of tiedown systems to resist base shear in the longitudinal direction.

o In seismic zones where $A_{a}$ or $Z \geq 0.2$, structural detailing should provide for inelastic deformations beyond first yield, and ductile connections should be provided between the supporting piers and the main frame of the manufactured home.

o When conventional shallow soil-anchors are used for windstorm protection, they should be installed vertically to maximum depth and preloaded in the direction of the service load to ensure sufficient system stiffness and withdrawal capacity.

o The traditional shallow soil-anchor/tie/pier system should not be used for windstorm protection where the basic wind speed exceeds $44.7 \mathrm{~m} / \mathrm{s}(100 \mathrm{mph})$. 
o The loads and load combinations discussed in this report are factored loads intended for use with a load and resistance factor design (LRFD) format. Appropriate adjustments will have to be made if an allowable stress design (ASD) format is used.

o In the interest of promoting better resistance to wind and seismic forces, prescriptive requirements for the design of tiedown systems should be abandoned in favor of performance-based design criteria. A set of performance-based criteria is proposed in this report.

\subsection{REFERENCES}

ANSI/ANS (1983). Standard for Estimating Tornado and Extreme Wind Characteristics at Nuclear Power Sites. ANSI/ANS 2.3, American Nuclear Society, La Grange Park, IL, xx pp.

ASCE (1994). Minimum Design Loads for Buildings and Other Structures. ASCE 7-93, American Society of Civil Engineers, New York, NY, 134 pp.

Earth-Lok (1994). Product data. Earth-Lok Technologies, Inc., Tustin, CA.

Fujita, T.T. (1971). "Workbook of Tornadoes and High Winds for Engineering Applications." SMRP Paper 165, University of Chicago, Chicago, IL.

Gupta, A.K. and Moss, P.J. (Eds.) (1993). Guidelines for Design of Low-Rise Buildings Subjected to Lateral Forces. CRC Press, Inc., Boca Raton, FL, 286 pp.

Hansing, R.F. (1994). "Dead Load Settling, Lateral Force Deflection, and Resultant of Wind Lateral and Uplift Forces for SP2000 Foundation Systems for Manufactured Homes." TRA Test Report, Project No. 4142, T.R. Arnold \& Associates, Inc., Elkhart, IN, 37 pp.

HUD (1989). Permanent Foundations Guide for Manufactured Housing, Handbook 4930.3, Prepared by Small Homes Council-Building Research Council, University of Illinois, for Office of Policy Development and Research, U.S. Department of Housing and Urban Development, Washington, DC.

HUD (1994). Final Rule - Manufactured Home Construction and Safety Standards on Wind Standards, Office of the Assistant Secretary for Housing, Dept. of Housing and Urban Development, Federal Register, Vol. 59, No. 10, 2456-2474.

Kovacs, W.D. and Yokel, F.Y. (1979). "Soil and Rock Anchors for Mobile Homes - A Stateof-the-Art Report." NBS Building Science Series 107, National Bureau of Standards, Washington, DC, $147 \mathrm{pp}$. 
Longinow, A., Meinheit, D.F. and Pearson, J.E. (1991). "Testing of Soil Anchors and Strapping." Report No. WJE 901798, prepared for U.S. Dept. of Housing and Urban Development, WJE Associates, Inc., Northbrook, IL, 67 pp.

Marshall, R.D. (1977). "The Measurement of Wind Loads on a Full-Scale Mobile Home." NBSIR 77-1289, National Bureau of Standards, Washington, DC, 120 pp.

Marshall, R.D. (1993). "Wind Load Provisions of the Manufactured Home Construction and Safety Standards - A Review and Recommendations for Improvement." NISTIR 5189, National Institute of Standards and Technology, Gaithersburg, MD, 90 pp.

Marshall, R.D. (1994). "Manufactured Homes - Probability of Failure and the Need for Better Windstorm Protection Through Improved Anchor Systems." NISTIR 5370, National Institute of Standards and Technology, Gaithersburg, MD, $42 \mathrm{pp}$.

MHCSS (1992). Manufactured Home Construction and Safety Standards, 24 CFR, Chapter XX, Pt. 3280, pp 196-223.

NCSBCS (1994). American National Standard - Manufactured Home Installations, NCSBCS/ANSI A225.1-1994. National Conference of States on Building Codes and Standards, Inc., Herndon, VA, 56 pp.

NCSBCS (1994). "Northridge Earthquake Effect on Manufactured Housing in California." Report prepared for Department of Housing and Urban Development by National Conference of States on Building Codes and Standards, Inc., Herndon, VA, 29 pp.

NEHRP (1991). NEHRP Recommended Provisions for the Development of Seismic Regulations for New Buildings, Building Seismic Safety Council, Federal Emergency Management Agency, 1991 edition.

NRC (1993). Wind and the Built Environment - U.S. Needs in Wind Engineering and Hazard Mitigation. Committee on Natural Disasters, Commission on Engineering and Technical Systems, National Research Council, National Academy Press, Washington, DC, 130 pp.

Simiu, E., Changery, M.J. and Filliben, J.J. (1979). "Extreme Wind Speeds at 129 Stations in the Contiguous United States." NBS Building Science Series 142, National Bureau of Standards, Washington, DC, $147 \mathrm{pp}$.

Todd, D., Carino, N., Chung, R.M., Lew, H.S., Taylor, A.W., Walton, W.D., Cooper, J.D. and Nimis, R. (1994). "1994 Northridge Earthquake - Performance of Structures, Lifelines, and Fire Protection Systems." NIST Special Publication 862, National Institute of Standards and Technology, Gaithersburg, MD, $181 \mathrm{pp}$. 
Tucker, J.W. (1994). "The Tucker Tripod Permanent Foundation System for Manufactured Structures." Product data. J.E. Tucker, Austin, TX, $11 \mathrm{pp.}$

Twisdale, L.A. and Dunn, W.L. (1983). "Probabilistic Analysis of Tornado Wind Risks." Journal of Structural Engineering, American Society of Civil Engineers, New York, Vol. 109, No. 2, pp 468-488.

UBC (1994). Uniform Building Code, 1994 Edition, International Conference of Building Officials, Whittier, CA.

Yokel, F.Y., Chung, R.M., Rankin, F.A. and Yancey, C.W.C. (1982). "Load-Displacement Characteristics of Shallow Soil Anchors." NBS Building Science Series 142, National Bureau of Standards, Washington, DC, 147 pp.

\section{ACKNOWLEDGMENTS}

For his many useful suggestions and for the numerous reference materials that aided in the conduct of this study, the authors wish to thank Mr. William Freeborne of the Affordable Housing Research and Technology Division, Office of Research, Evaluation and Monitoring, U.S. Department of Housing and Urban Development. The authors are indebted to Dr. Long T. Phan of the Structures Division, Building and Fire Research Laboratory, NIST, and to Professor Dale C. Perry, Department of Architecture, Texas A\&M University, for reviewing the manuscript and for offering many constructive comments. 


\section{APPENDIX A - SAMPLE LOAD CALCULATIONS}

Sample Load Calculations for Table 5

Assumptions:

$$
\begin{aligned}
& \mathrm{a}=2.134 \mathrm{~m} \quad(7 \mathrm{ft}) \\
& \mathrm{b}=4.267 \mathrm{~m} \quad(14 \mathrm{ft}) \\
& \mathrm{h}=2.438 \mathrm{~m} \quad(8 \mathrm{ft}) \\
& \alpha=15 \text { degrees } \\
& \theta=45 \text { degrees }
\end{aligned}
$$

Dead load $=1.20 \mathrm{kPa} \quad(25 \mathrm{psf})$

MHCSS Zone I Nominal

Wind Loads (See Table 4):

$$
\begin{aligned}
& \mathrm{P}_{\mathrm{W}}=0.72 \mathrm{kPa} \quad(15 \mathrm{psf}) \\
& \mathrm{P}_{\mathrm{RW}}=0.43 \mathrm{kPa} \quad(9 \mathrm{psf}) \\
& \mathrm{P}_{\mathrm{RL}}=0.43 \mathrm{kPa} \quad(9 \mathrm{psf})
\end{aligned}
$$

MHCSS Zone I Factored Loads:

$\sum F_{x}=0$

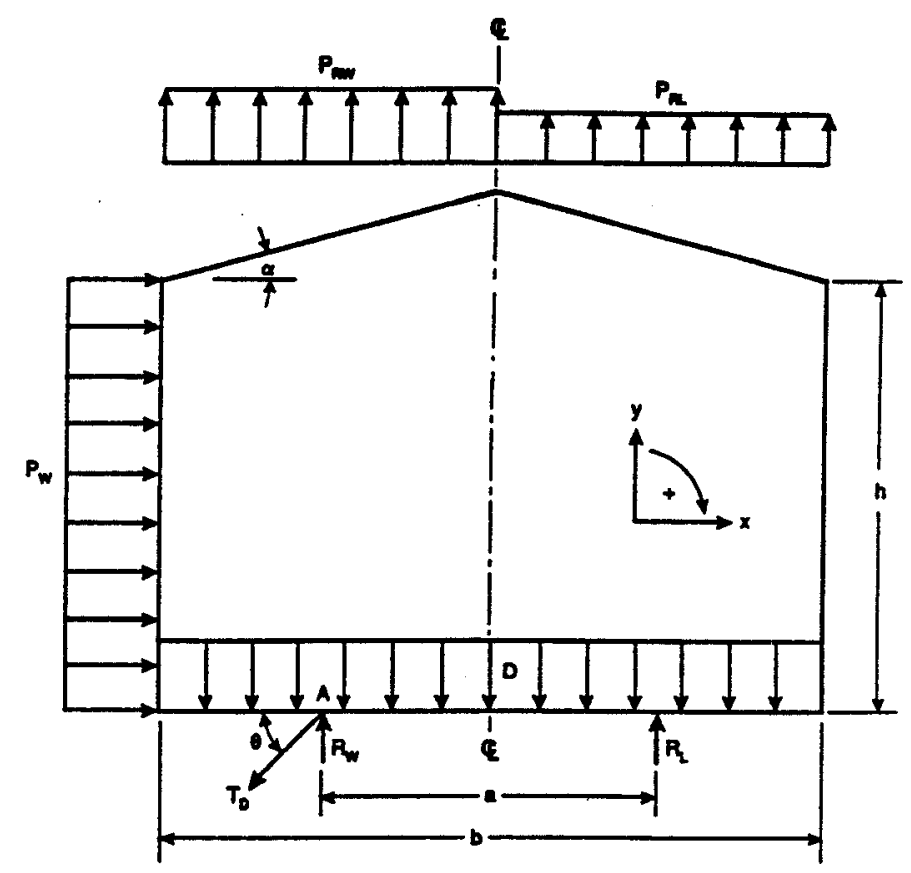

$$
\begin{aligned}
& \left(\gamma_{\mathrm{w}}\right)\left(\mathrm{P}_{\mathrm{w}}\right)(\mathrm{h})-\left(\mathrm{T}_{\mathrm{D}}\right)(\operatorname{Cos} \theta)=0 \\
& \mathrm{~T}_{\mathrm{D}}=(1.5)(0.72)(2.438) /(\operatorname{Cos} 45) \\
& \mathrm{T}_{\mathrm{D}}=3.71 \mathrm{kN} / \mathrm{m} \quad(255 \mathrm{lbf} / \mathrm{ft})
\end{aligned}
$$

$\Sigma \mathrm{M}_{\mathrm{A}}=0$

$$
\begin{aligned}
\left(\gamma_{\mathrm{W}}\right)\left(\mathrm{P}_{\mathrm{w}}\right)(\mathrm{h})(\mathrm{h} / 2)+\left(\gamma_{\mathrm{w}}\right)\left(\mathrm{P}_{\mathrm{RW}}\right)(\mathrm{b} / 2)(\mathrm{b} / 4-\mathrm{a} / 2)-\left(\gamma_{\mathrm{w}}\right)\left(\mathrm{P}_{\mathrm{RL}}\right)(\mathrm{b} / 2)(\mathrm{b} / 4+\mathrm{a} / 2)+(\mathrm{D})(\mathrm{b})(\mathrm{a} / 2) \\
-\left(\mathrm{R}_{\mathrm{L}}\right)(\mathrm{a})=0 \\
\mathrm{R}_{\mathrm{L}}=[(1.5)(0.72)(2.438)(1.219)+(1.5)(0.43)(2.133)(1.067-1.067) \\
\quad-(1.5)(0.43)(2.133)(1.067+1.067)+(1.20)(4.267)(1.067)] / 2.134 \\
\mathrm{R}_{\mathrm{L}}=2.68 \mathrm{kN} / \mathrm{m}(183 \mathrm{lbf} / \mathrm{ft})
\end{aligned}
$$

$\sum F_{Y}=0$

$$
\mathrm{R}_{\mathrm{w}}+\mathrm{R}_{\mathrm{L}}+\left(\gamma_{\mathrm{W}}\right)\left(\mathrm{P}_{\mathrm{RW}}\right)(\mathrm{b} / 2)+\left(\gamma_{\mathrm{w}}\right)\left(\mathrm{P}_{\mathrm{RL}}\right)(\mathrm{b} / 2)-(\mathrm{D})(\mathrm{b})-\left(\mathrm{T}_{\mathrm{D}}\right)(\operatorname{Sin} \theta)=0
$$




$$
\begin{aligned}
& \mathrm{R}_{\mathrm{w}}=-2.68-(1.5)(0.43)(2.133)-(1.5)(0.43)(2.133)+(1.20)(4.267)+(3.71)(\operatorname{Sin} 45) \\
& \mathbf{R}_{\mathrm{w}}=2.30 \mathrm{kN} / \mathrm{m} \quad(158 \mathrm{lbf} / \mathrm{ft})
\end{aligned}
$$

ASCE 7-93 Zone I Nominal Loads:

Basic Wind Speed $=31.3 \mathrm{~m} / \mathrm{s}(70 \mathrm{mph})$

(See Table 4)

$$
\begin{aligned}
& \mathrm{P}_{\mathrm{W}}=0.82 \mathrm{kPa} \quad(17.2 \mathrm{psf}) \\
& \mathrm{P}_{\mathrm{RW}}=0.57 \mathrm{kPa} \quad(11.9 \mathrm{psf}) \\
& \mathrm{P}_{\mathrm{RL}}=0.45 \mathrm{kPa} \quad(9.3 \mathrm{psf})
\end{aligned}
$$

ASCE 7-93 Factored Loads:

$$
\begin{aligned}
& \sum \mathrm{F}_{\mathrm{X}}= 0 \\
&\left(\gamma_{\mathrm{W}}\right)\left(\mathrm{P}_{\mathrm{W}}\right)(\mathrm{h})-\left(\mathrm{T}_{\mathrm{D}}\right)(\operatorname{Cos} \theta)=0 \\
& \mathrm{~T}_{\mathrm{D}}=(1.3)(0.82)(2.438) /(\operatorname{Cos} 45) \\
& \mathrm{T}_{\mathrm{D}}=3.69 \mathrm{kN} / \mathrm{m}(253 \mathrm{lbf} / \mathrm{ft}) \\
& \sum \mathrm{M}_{\mathrm{A}}=0 \\
&\left(\gamma_{\mathrm{W}}\right)\left(\mathrm{P}_{\mathrm{W}}\right)(\mathrm{h})(\mathrm{h} / 2)+\left(\gamma_{\mathrm{W}}\right)\left(\mathrm{P}_{\mathrm{RW}}\right)(\mathrm{b} / 2)(\mathrm{b} / 4-\mathrm{a} / 2)-\left(\gamma_{\mathrm{W}}\right)\left(\mathrm{P}_{\mathrm{RL}}\right)(\mathrm{b} / 2)(\mathrm{b} / 4+\mathrm{a} / 2)+\left(\gamma_{\mathrm{D}}\right)(\mathrm{D})(\mathrm{b})(\mathrm{a} / 2) \\
&-\left(\mathrm{R}_{\mathrm{L}}\right)(\mathrm{a})=0 \\
& \mathrm{R}_{\mathrm{L}}=[(1.3)(0.82)(2.438)(1.219)+(1.3)(0.57)(2.133)(1.067-1.067) \\
&\quad-(1.3)(0.45)(2.133)(1.067+1.067)+(0.9)(1.20)(4.267)(1.067)] / 2.134 \\
& \mathrm{R}_{\mathrm{L}}=2.56 \mathrm{kN} / \mathrm{m}(175 \mathrm{lbf} / \mathrm{ft}) \\
& \sum \mathrm{F}_{\mathrm{Y}}=0 \\
& \mathrm{R}_{\mathrm{W}}+\mathrm{R}_{\mathrm{L}}+\left(\gamma_{\mathrm{W}}\right)\left(\mathrm{P}_{\mathrm{RW}}\right)(\mathrm{b} / 2)+\left(\gamma_{\mathrm{W}}\right)\left(\mathrm{P}_{\mathrm{RL}}\right)(\mathrm{b} / 2)-\left(\gamma_{\mathrm{D}}\right)(\mathrm{D})(\mathrm{b})-\left(\mathrm{T}_{\mathrm{D}}\right)(\operatorname{Sin} \theta)=0 \\
& \mathrm{R}_{\mathrm{W}}=-2.56-(1.3)(0.57)(2.133)-(1.3)(0.45)(2.133)+(0.9)(1.20)(4.267) \\
& \quad+(3.69)(\operatorname{Sin} 45) \\
& \mathrm{R}_{\mathrm{W}}=1.84 \mathrm{kN} / \mathrm{m}(126 \mathrm{lbf} / \mathrm{ft})
\end{aligned}
$$




\section{Sample Load Calculations for Table 8}

MHCSS Zone I Factored Loads:

$\sum F_{X}=0$

$\left(\gamma_{\mathrm{w}}\right)\left(\mathrm{P}_{\mathrm{w}}\right)(\mathrm{h})-\mathrm{V}=0$

$\mathrm{V}=(1.5)(0.72)(2.438)$

$\mathrm{V}=2.63 \mathrm{kN} / \mathrm{m}(180 \mathrm{lbf} / \mathrm{ft})$

$\sum \mathrm{M}_{\mathrm{A}}=0$

$\left(\gamma_{\mathrm{w}}\right)\left(\mathrm{P}_{\mathrm{w}}\right)(\mathrm{h})(\mathrm{h} / 2)+\left(\gamma_{\mathrm{w}}\right)\left(\mathrm{P}_{\mathrm{RW}}\right)(\mathrm{b} / 2)(\mathrm{b} / 4-\mathrm{a} / 2)-\left(\gamma_{\mathrm{w}}\right)\left(\mathrm{P}_{\mathrm{RL}}\right)(\mathrm{b} / 2)(\mathrm{b} / 4+\mathrm{a} / 2)+(\mathrm{D})(\mathrm{b})(\mathrm{a} / 2)$

$-\left(R_{L}\right)(a)=0$

$\mathbf{R}_{\mathbf{L}}=[(1.5)(0.72)(2.438)(1.219)+(1.5)(0.43)(2.133)(1.067-1.067)$ $-(1.5)(0.43)(2.133)(1.067+1.067)+(1.20)(4.267)(1.067)] / 2.134$

$R_{\mathrm{L}}=2.68 \cdot \mathrm{kN} / \mathrm{m}(183 \mathrm{lbf} / \mathrm{ft})$

$\sum F_{Y}=0$

$$
\begin{aligned}
& \mathbf{R}_{\mathbf{W}}+\mathbf{R}_{\mathrm{L}}+\left(\gamma_{\mathrm{W}}\right)\left(\mathrm{P}_{\mathrm{RW}}\right)(\mathrm{b} / 2)+\left(\gamma_{\mathrm{W}}\right)\left(\mathrm{P}_{\mathrm{RL}}\right)(\mathrm{b} / 2)-(\mathrm{D})(\mathrm{b})=0 \\
& \mathbf{R}_{\mathbf{W}}=-2.68-(1.5)(0.43)(2.133)-(1.5)(0.43)(2.133)+(1.20)(4.267) \\
& \mathbf{R}_{\mathbf{W}}=-0.33 \mathrm{kN} / \mathrm{m} \quad(-22 \mathrm{lbf} / \mathrm{ft})
\end{aligned}
$$

ASCE 7-93 Zone I Factored Loads:

Basic Wind Speed $=31.3 \mathrm{~m} / \mathrm{s}(70 \mathrm{mph})$

$$
\begin{aligned}
& \sum \mathrm{F}_{\mathrm{X}}=0 \\
& \left(\gamma_{\mathrm{w}}\right)\left(\mathrm{P}_{\mathrm{w}}\right)(\mathrm{h})-\mathrm{V}=0 \\
& \mathrm{~V}=(1.3)(0.82)(2.438) \\
& \mathrm{V}=2.61 \mathrm{kN} / \mathrm{m} \quad(179 \mathrm{lbf} / \mathrm{ft})
\end{aligned}
$$




$$
\begin{aligned}
& \sum \mathrm{M}_{\mathrm{A}}=0 \\
&\left(\gamma_{\mathrm{W}}\right)\left(\mathrm{P}_{\mathrm{W}}\right)(\mathrm{h})(\mathrm{h} / 2)+\left(\gamma_{\mathrm{W}}\right)\left(\mathrm{P}_{\mathrm{RW}}\right)(\mathrm{b} / 2)(\mathrm{b} / 4-\mathrm{a} / 2)-\left(\gamma_{\mathrm{W}}\right)\left(\mathrm{P}_{\mathrm{RL}}\right)(\mathrm{b} / 2)(\mathrm{b} / 4+\mathrm{a} / 2)+\left(\gamma_{\mathrm{D}}\right)(\mathrm{D})(\mathrm{b})(\mathrm{a} / 2) \\
&-\left(\mathrm{R}_{\mathrm{L}}\right)(\mathrm{a})=0 \\
& \mathrm{R}_{\mathrm{L}}=[(1.3)(0.82)(2.438)(1.219)+(1.3)(0.57)(2.133)(1.067-1.067) \\
&\quad-(1.3)(0.45)(2.133)(1.067+1.067)+(0.9)(1.20)(4.267)(1.067)] / 2.134 \\
& \mathrm{R}_{\mathrm{L}}=2.56 \mathrm{kN} / \mathrm{m}(175 \mathrm{lbf} / \mathrm{ft}) \\
& \sum \mathrm{F}_{\mathrm{Y}}=0 \\
& \mathrm{R}_{\mathrm{W}}+\mathrm{R}_{\mathrm{L}}+\left(\gamma_{\mathrm{W}}\right)\left(\mathrm{P}_{\mathrm{RW}}\right)(\mathrm{b} / 2)+\left(\gamma_{\mathrm{W}}\right)\left(\mathrm{P}_{\mathrm{RL}}\right)(\mathrm{b} / 2)-\left(\gamma_{\mathrm{D}}\right)(\mathrm{D})(\mathrm{b})=0 \\
& \mathrm{R}_{\mathrm{W}}=-2.56-(1.3)(0.57)(2.133)-(1.3)(0.45)(2.133)+(0.9)(1.20)(4.267) \\
& \mathrm{R}_{\mathrm{W}}=-0.77 \mathrm{kN} / \mathrm{m} \quad(-53 \mathrm{lbf} / \mathrm{ft})
\end{aligned}
$$




\title{
APPENDIX B - COMPUTER PROGRAM FOR CALCULATING WIND LOAD REACTIONS
}

\author{
Program Listing in GWBASIC
}

10 REM PROGRAM FOR GALCULATING SINGLE-WIDE MANUFACTURED HOME REACTIONS

20 REM LATERAL RESISTANCE OF PIERS ASSUMED TO BE ZERO

30 CLS:PRINT "PROGRAY FOR CALCULATING SINGLE-WIDE MANUFACTURED HOME REACTIONS

40 PRINT: INPUT "NET BOX HEIGHT (FEET) - - H

50 PRINT: INPUT "OVERALL WIDTH (FEET) $=\cdots, W$

60 PRINT: INPUT "MAIN-FRAME SPACING (FEET) - - B

70 PRINT: INPUT "NOMINAL DRAG LOAD (PSF) = - PW

80 PRINT: INPUT "NOMINAL UPLIFT LOAD ON WINDWARD ROOF (PSF) - ", PRW

90 PRINT: INPUT "NOMINAL UPLIFT LOAD ON LEEWARD ROOF (PSF) - ", PRL

100 PRINT: INPUT "NOMINAL DEAD LOAD (PSF) - ",DL

110 PRINT:INPUT NDEAD LOAD ECCENTRICITY (POSITIVE IF UPWIND \& NEGATIVE IF DOWNWI ND OF HOME CENTERLINE) (FEET) - ",E

120 PRINT: INPUT "LOAD FACTOR FOR WIND LOAD $="$ ", GAMMAW

130 PRINT: INPUT "LOAD FACTOR FOR DEAD LOAD - ", GAMMAD

140 PRINT:PRINT "WAIT - COMPUTING"

$150 M-1$

160 OPTION BASE 1

170 DIM $L(20,10)$

$180 \mathrm{~A}-(\mathrm{W}-\mathrm{B}) / 2$

190 REM DETERMINATION OF CRITICAL TIE ANGLE

$200 R L-\left(D L * W *(B / 2-E)+P W * H^{\wedge} 2 / 2-(W / 4-A) * P R W * W / 2-(3 * W / 4-A) \star P R L * W / 2\right) / B$ 210 IF RL $<0$ THEN GOTO 250

220 TANCR $-\left(-D L * W *(B / 2+E)+P W * H^{\wedge} 2 / 2+(3 * W / 4-A) * P R W * W / 2+(W / 4-A) * P R L * W /\right.$ 2) $/(P W * H * B)$

230 IF TANCR < 0 THEN TANCR - 0

240 GOTO 270

250 TANCR $-\left(-D L * W *(W / 2+E)+P W * H^{\wedge} 2 / 2+P R W * 3 * W^{\wedge} 2 / 8+P R I * W^{\wedge} 2 / 8\right) /(P W * H *(A+B)$ )

260 IF TANCR < 0 THEN TANCR - 0

270 FOR $N=1$ TO 13

280 THETA $-5 *(\mathrm{~N}+1)$

290 NUM - (THETA/180)*3.14159

$300 L(N, 1)$ - THETA

$310 \mathrm{TD}-\mathrm{PW}$ *H/COS (NUM)

$320 \mathrm{~L}(\mathrm{~N}, 2)-\mathrm{TD}$

330 IF TAN(NUM) < TANCR GOTO 530

340 REM REACTIONS FOR TIE ANGLE $\rightarrow$ CRITICAL

$350 R I=\left(D L * W *(B / 2-E)+P W * H^{\wedge} 2 / 2-(W / 4-A) * P R W * W / 2-(3 * W / 4-A) * P R I * W / 2\right) / B$

360 IF RL $<0$ THEN GOTO 450

370 REM REACTIONS FOR LEEWARD PIER IN COMPRESSION

$380 \mathrm{RW}-\mathrm{PW} * \mathrm{H} * \mathrm{TAN}(\mathrm{NUM})-\mathrm{RL}+\mathrm{DL} * \mathrm{~W}-\mathrm{PRW} * \mathrm{~W} / 2-\mathrm{PRL} * \mathrm{~W} / 2$

$390 \mathrm{~L}(\mathrm{~N}, 3)-\mathrm{RW}$

$400 L(N, 4)-R L$

$410 \mathrm{~L}(\mathrm{~N}, 5)=0$

$420 L(N, 6)=0$

430 GOTO 690

440 REM REACTIONS FOR LEEWARD VERTICAL TIE IN TENSION

$450 \mathrm{TVL}=\left(-D L * W *(B / 2-E)-P W * H^{\wedge} 2 / 2+(W / 4-A) * P R W * W / 2+(3 * W / 4-A) * P R L * W / 2\right)$

$1(\mathrm{~A}+\mathrm{B})$

$460 \mathrm{RW}-\mathrm{PW} * \mathrm{H} * \mathrm{TAN}(\mathrm{NUM})+\mathrm{TVL}+\mathrm{DL} * \mathrm{~W}-\mathrm{PRW} * \mathrm{~W} / 2-\mathrm{PRL} * \mathrm{~W} / 2$

$470 \mathrm{~L}(\mathrm{~N}, 3)-\mathrm{RW}$

$480 L(N, 4)=0$

$490 L(N, 5)=0$

$500 \mathrm{~L}(\mathrm{~N}, 6)=\mathrm{TVL}$

510 GOTO 690

520 REM REACTIONS FOR TIE ANGLE < CRITICAL

$530 R L=\left(T D * A * S I N(N U M)+D L * W *(A+B / 2-E)+P W * H^{\wedge} 2 / 2-P R W^{\wedge} 2 / 8-P R L * 3 * W^{\wedge} 2 /\right.$ 8) $/(A+B)$

540 IF RL $<0$ GOTO 630

550 RFM REACTIONS FOR IEEWARD PIER IN COMPRESSION 


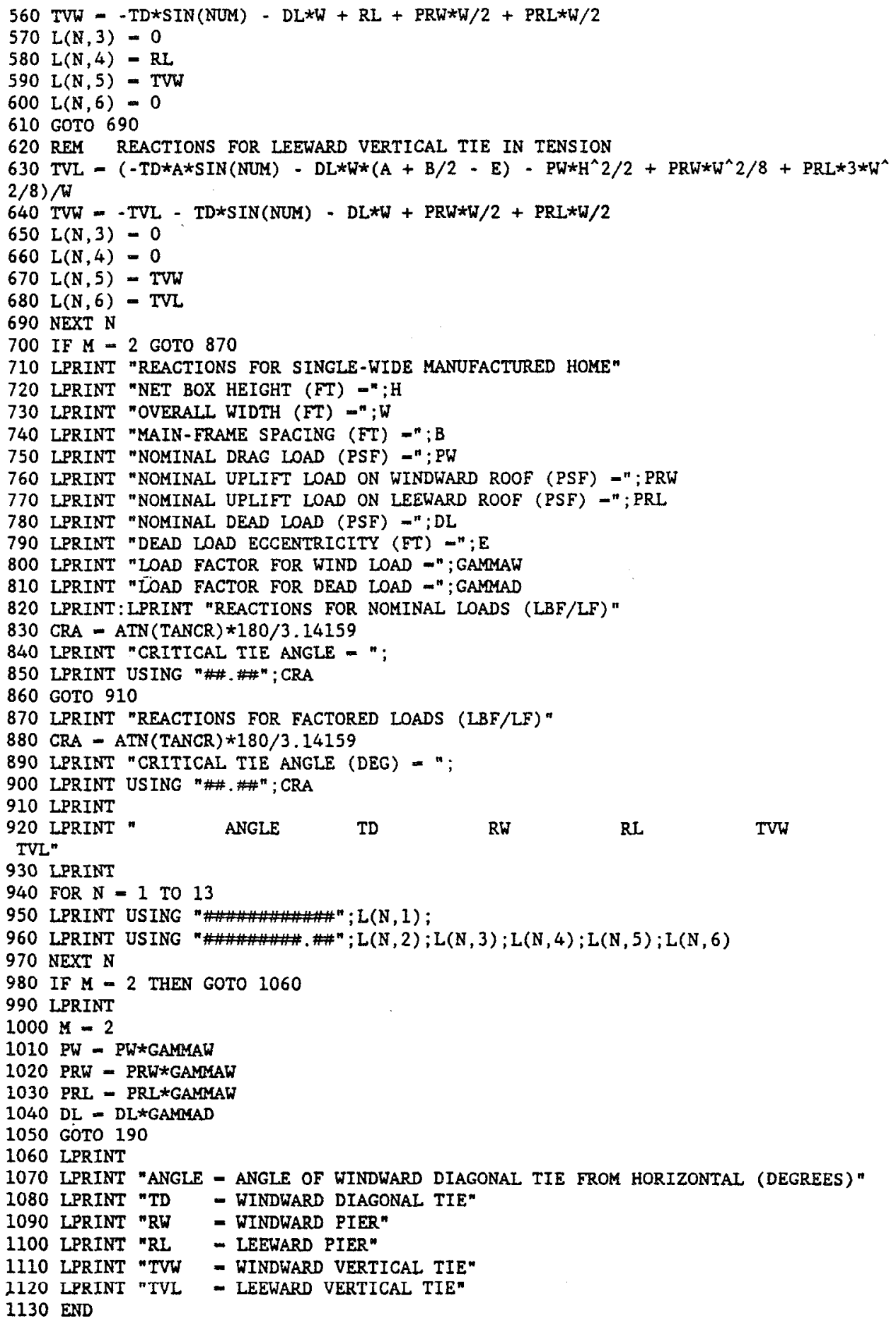

- WINDWARD DIAGONAL TIE"

- WINDWARD PIER"

- LEEWARD PIER"

- WINDWARD VERTICAL TIE"

- LEEWARD VERTICAL TIE" 


\section{Sample Output}

REACTIONS FOR SINGLE-WIDE MANUFACTURED HOME

NET BOX HEIGHT (FT) -8

OVERALL WIDTH (FT) $=14$

MAIN-FRAME SPACING (FT) -7

NOMTNAL DRAG LOAD (PSF) -38.8

NOMINAL UPIIFT LOAD ON WINDWARD ROOF (PSF) -26.9

NOMINAL UPLIFT LOAD ON LEEWARD ROOF (PSF) $=20.8$

NOMINAL DEAD LOAD (PSF) $=25$

DEAD LOAD ECCENTRICITY (FT) - 0

LOAD FACTOR FOR WIND LOAD $=1.3$

LOAD FACTOR FOR DEAD LOAD - .9

REACTIONS FOR NOMINAL LOADS (LBF/LF)

CRITICAL TIE ANGLE = 31.56

$\begin{array}{cccccc}\text { ANGLE } & \text { TD } & \text { RW } & \text { RI } & \text { TVW } & \text { TVL } \\ & & & & & \\ 10 & 315.19 & 0.00 & 161.46 & 90.63 & 0.00 \\ 15 & 321.35 & 0.00 & 170.94 & 71.67 & 0.00 \\ 20 & 330.32 & 0.00 & 180.87 & 51.80 & 0.00 \\ 25 & 342.49 & 0.00 & 191.46 & 30.62 & 0.00 \\ 30 & 358.42 & 0.00 & 202.95 & 7.64 & 0.00 \\ 35 & 378.93 & 26.67 & 206.77 & 0.00 & 0.00 \\ 40 & 405.20 & 69.78 & 206.77 & 0.00 & 0.00 \\ 45 & 438.97 & 119.73 & 206.77 & 0.00 & 0.00 \\ 50 & 482.90 & 179.25 & 206.77 & 0.00 & 0.00 \\ 55 & 541.17 & 252.62 & 206.77 & 0.00 & 0.00 \\ 60 & 620.80 & 346.96 & 206.77 & 0.00 & 0.00 \\ 65 & 734.47 & 474.98 & 206.77 & 0.00 & 0.00 \\ 70 & 907.55 & 662.14 & 206.77 & 0.00 & 0.00\end{array}$

REACTIONS FOR FACTORED LOADS (LBE/LF)

CRITICAL TIE ANGLE (DEG) $=38.23$

\begin{tabular}{ccrcrr} 
ANGLE & \multicolumn{1}{c}{ TD } & RW & RL & TVW & TVI \\
& & & & & \\
10 & 409.74 & 0.00 & 116.56 & 164.48 & 0.00 \\
15 & 417.75 & 0.00 & 128.89 & 139.83 & 0.00 \\
20 & 429.42 & 0.00 & 141.80 & 114.00 & 0.00 \\
25 & 445.23 & 0.00 & 155.57 & 86.47 & 0.00 \\
30 & 465.94 & 0.00 & 170.50 & 56.60 & 0.00 \\
35 & 492.61 & 0.00 & 187.03 & 23.55 & 0.00 \\
40 & 526.76 & 20.72 & 198.80 & 0.00 & 0.00 \\
45 & 570.66 & 85.65 & 198.80 & 0.00 & 0.00 \\
50 & 627.77 & 163.02 & 198.80 & 0.00 & 0.00 \\
55 & 703.51 & 258.41 & 198.80 & 0.00 & 0.00 \\
60 & 807.04 & 381.04 & 198.80 & 0.00 & 0.00 \\
65 & 954.81 & 547.48 & 198.80 & 0.00 & 0.00 \\
70 & 1179.81 & 790.79 & 198.80 & 0.00 & 0.00
\end{tabular}

ANGLE - ANGLE OF WINDWARD DIAGONAL TIE FROM HORIZONTAL (DEGREES)

TD - WINDWARD DIAGONAL TIE

RW - WINDWARD PIER

RL - LEEWARD PIER

TVW - WINDWARD VERTICAL TIE

TVL - LEEWARD VERTICAL TIE 


\title{
APPENDIX C - OVERVIEW OF SELECTED REQUIREMENTS FOR WINDSTORM PROTECTION
}

\author{
Manufactured Home Construction and Safety Standards (MHCSS)
}

\begin{abstract}
Although MHCSS-1994 contains requirements for windstorm protection, the Department of Housing and Urban Development does not regulate the design or installation of anchoring and support systems, this responsibility being left to the individual States and local governments. Basically, the MHCSS criteria for windstorm protection require the application of the design wind loads (combined drag and uplift) for the three wind zones (see Figure 1) with the design wind loads for Zone I being multiplied by a factor of 1.5. The full dead load of the home, but not the live load or any fraction thereof, may be included in the determination of support and anchoring system reactions due to wind loading. For allowable stress design (ASD), the MHCSS does not permit any increase in allowable stresses for wind loading. Anchoring equipment must be capable of resisting an allowable working load equal to or exceeding 14.0 $\mathrm{kN}(3,150 \mathrm{lbf})$ and must be capable of withstanding a 50 percent overload, $21.0 \mathrm{kN}(4,725 \mathrm{lbf})$ total, without failure of either the anchoring equipment or the attachment point on the manufactured home.
\end{abstract}

The MHCSS recommends that ground anchors be installed to their full depth and that stabilizer plates be installed to provide added resistance to overturning or sliding forces. Ties are to be evenly spaced as practicable along the length of the manufactured home with not more than 0.61 $\mathrm{m}(2 \mathrm{ft})$ open-end spacing on each end. In wind Zone I only diagonal frame ties are required. For manufactured homes sited in wind Zones II and III, a vertical tie is required at each diagonal tie location.

\section{NCSBCS/ANSI A225.1-1994}

American National Standard NCSBCS/ANSI A225.1-1994 for Manufactured Home Installations is not written in mandatory language and is, therefore, along the lines of a manual of recommended practice. For normal home installations the A225.1 Standard recognizes the following types of foundation systems:

Piers and soil anchors

Concrete slab or continuous footings

Pile/post system

Concrete, concrete block or wood foundations and load-bearing perimeter walls

Piers may be concrete block, pressure-treated wood, or adjustable metal or concrete units. The use of single-stacked concrete block is acceptable for pier heights of less than $0.91 \mathrm{~m} \mathrm{(36} \mathrm{in.)}$ while the use of double-stacked, interlocked concrete block is acceptable for pier heights up to $2.03 \mathrm{~m}(80 \mathrm{in}$.). In general, end piers are to be located no more than $0.61 \mathrm{~m}(2 \mathrm{ft})$ from either end of the manufactured home and spaced not more than $2.44 \mathrm{~m}(8 \mathrm{ft})$ center-to-center under the longitudinal beams of the main frame, but loading tables are provided for pier spacings of 
up to $3.05 \mathrm{~m}(10 \mathrm{ft})$.

The wind zones and corresponding net drag and uplift loads defined in the MHCSS-1994 are referenced in NCSBCS/ANSI A225.1-1994. However, A225.1-1994 does not mention the requirement that the Zone I drag and uplift loads are to be multiplied by a factor of 1.5 when proportioning windstorm protection systems. All anchoring components are to be certified as having a $21.0 \mathrm{kN}(4,725 \mathrm{lbf})$ load capacity, and this same load capacity is implied for anchor pull-out resistance. However, no guidelines are provided for the estimation of pull-out capacity on the basis of either soil classification or field testing. When using a single tie, the shaft of the ground anchor is to be aligned with the tie. For diagonal ties, the angle between the tie and the vertical may range from 40 to 50 degrees. When connecting more than one tie to a single anchor, the anchor shaft is to be aligned with the resultant of the tie forces. Installations in wind Zones II and III require that a vertical tie be installed at each diagonal tie location. Soil anchors may be installed vertically, provided that either a $254 \times 457 \mathrm{~mm}(10 \times 18$ in.) concrete collar or an approved metal stabilizing device is installed on the anchor shaft. There is no limitation on anchor head displacement under load.

The maximum allowable anchor spacing is as follows:

$\begin{array}{lll}\text { Zone I } & 3.35 \mathrm{~m} & (11 \mathrm{ft}) \\ \text { Zone II } & 1.83 \mathrm{~m} & (6 \mathrm{ft}) \\ \text { Zone III } & 1.37 \mathrm{~m} & (4.5 \mathrm{ft})\end{array}$

Manufactured homes destined for special wind regions of Zone I are to be designed and installed on the basis of the wind loads for Zone II.

\section{Selected State Requirements for Windstorm Protection}

A summary of selected State requirements for manufactured home support and windstorm protection is provided herein. These requirements do not reflect the changes in the MHCSS for hurricane zones issued in 1994 or the current requirements of NCSBCS/ANSI A225.1-1994 for wind Zones II and III. However, the rules issued by the State of California appear to reflect experience gained from the Northridge Earthquake of January 17, 1994. Of particular note is the California requirement that at least two tiedown assemblies be installed at each end of each transportable section of the home to provide longitudinal stability. In addition, there is a requirement that concrete or steel piers have mechanical connections to the home and to their footings to forestall separation under horizontal or vertical loads. Prescriptive requirements for the pier to main-frame connections are included. Florida and Minnesota also require secure attachment of such piers to the main frame while Texas does not.

With regard to allowable anchor displacements under load, all of the State requirements summarized herein place limits on vertical and horizontal movement of the anchor head. Only Florida requires the installation of stabilizer plates, and these are limited to auger-type anchors having frame-tie connections. In general, the number and spacing of ties are to be in accordance 
with the manufacturer's installation instructions, or in accordance with the provisions of NCSBCS A225.1-1987, Manufactured Home Installations.

Most State requirements stipulate that manufactured homes constructed in compliance with the MHCSS requirements be anchored in accordance with the manufacturer's installation instructions or in accordance with certain generic standards that also apply to homes constructed prior to the issuance of the MHCSS requirements.

\section{CALIFORNIA:}

On October 28, 1994, the Department of Housing and Community Development provided notice to the public of proposed amendments to existing regulations and newly proposed regulations that govern the installation on a support system of manufactured homes and mobile homes. The regulations are currently in effect on an emergency basis, and the Department is accepting for further consideration written comments from the public. The following is a summary of selected requirements as of April 1995.

o Design Loads:

Wind Load: The side-wall area (excluding skirting) plus half the horizontally projected area of the roof structure, all multiplied by the manufactured home design wind pressure or $718 \mathrm{~Pa}(15 \mathrm{psf})$, whichever is greater.

Snow Load: Depends upon designated Region (I, II or III) and local elevation. Snow loads can range from 958 to $3,830 \mathrm{~Pa}$ (20 to $80 \mathrm{psf}$ ).

o Pier Spacing:

Homes manufactured prior to October 7, 1973, or homes for which the manufacturer's installation instructions are unobtainable, shall be supported by load bearing supports or a support structure under its main chassis beams, spaced not more than $1.83 \mathrm{~m}(6 \mathrm{ft})$ apart longitudinally and under ridge beam supports.

o Pier to Main-Frame Connection:

When used, concrete or steel piers shall have mechanical connections to the home and their footing that resist separation of the supports from the home and the footing. The means of mechanical connection shall not allow the separation of the home from any pier or footing as a result of horizontal loads or vertical loads.

Mechanical connection of the concrete pier or steel pier to the point of attachment on the home shall comply with the following requirements: (1) The means of mechanical connection shall be fabricated steel that is not less than $3 \mathrm{~mm}(1 / 8 \mathrm{in}$.) thick and not less than $51 \mathrm{~mm}(2 \mathrm{in}$.) wide and $51 \mathrm{~mm}(2 \mathrm{in}$.) long; (2) Fasteners incorporated as part of the mechanical connection shall be no smaller than $10 \mathrm{~mm}(3 / 8 \mathrm{in}$.), grade 5 bolts, nuts and lock washers; (3) The means of mechanical connection shall not incorporate modifications of either the pier or of the home; and (4) The means of mechanical 
connection at the center line between each transportable section of a multi-section home shall consist of $6 \mathrm{~mm}(1 / 4 \mathrm{in}$.) lag bolts or wood screws and shall secure the pier to a wood floor or structural member.

o Anchor and Tie Capacity:

A tiedown assembly shall be tested by applying an increasing test load to the point of failure in order to determine the assembly's capacity for resistance. A working load for the tiedown assembly shall be established from the test results which shall be two-thirds of the amount of resistance the tiedown assembly endured without failure.

- Allowable Anchor Displacements:

Vertical $=51 \mathrm{~mm}(2 \mathrm{in}$.) under application of test load.

Horizontal $=76 \mathrm{~mm}(3 \mathrm{in}$.) under application of test load.

o Stabilizer Plates:

Stabilizer plates are not required.

o Anchor or Tie Spacing:

New manufactured homes and park trailers shall be anchored to the specifications as provided by the manufactured home or park trailer manufacturer.

Used units where the manufacturer's specifications are not available shall be anchored every $1.83 \mathrm{~m}(6 \mathrm{ft})$ with anchors placed within $0.61 \mathrm{~m}(2 \mathrm{ft})$ of each end.

o Anchorage to Resist Forces in Longitudinal Direction:

No less than two tiedown assemblies shall be installed at each end of each transportable section of the home. The working load of the tiedown assemblies installed at each end of a home shall be the same as the working load of the tiedown assemblies installed along each of the longitudinal sides of the home.

Reference: Title 25, California Code of Regulations, Division 1, Chapter 2, Subchapter 1, Mobilehome Parks, Department of Housing and Community Development, Division of Codes and Standards. 


\section{FLORIDA}

- Design Loads:

Design loads are not specified.

- Pier Spacing:

Depending upon soil classification and footer size, maximum pier spacing can range from 0.91 to $3.35 \mathrm{~m} \mathrm{(3}$ to $11 \mathrm{ft})$.

o Pier to Main-Frame Connection:

Steel piers with mechanical adjustments shall be securely attached to the frame of all mobile/manufactured homes or park trailers.

- Anchor and Tie Capacity:

Working load $=21.0 \mathrm{kN}(4,725 \mathrm{lbf})$

- Allowable Anchor Displacements:

Vertical $=51 \mathrm{~mm}(2 \mathrm{in}$.$) with vertical tie loaded to 21.0 \mathrm{kN}(4,725 \mathrm{lbf})$

Horizontal $=76 \mathrm{~mm}(3 \mathrm{in}$.) with diagonal tie loaded to $21.0 \mathrm{kN}(4,725 \mathrm{lbf})$

- Stabilizer Plates:

All auger anchors having frame tie connections only shall have approved stabilizing plates installed on the inside (direction of pull) with the top of the stabilizing plate driven flush with the soil. Exception: Stabilizer plates are not required with coral anchors or at center line of marriage wall locations.

o Anchor and Tie Spacing:

Frame Ties:

New manufactured homes and park trailers shall be anchored to the specifications as provided by the manufactured home or park trailer manufacturer.

Used units where the manufacturer's specifications are not available shall be anchored

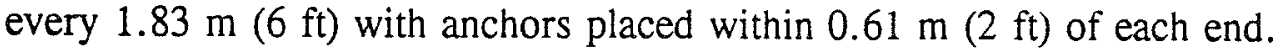

Vertical Ties:

Homes manufactured after June 15, 1976, and designated "Hurricane Resistant" shall not require roof ties.

Where factory installed roof ties are not evident and it cannot be determined that the home is "Hurricane Resistant" without such ties, then the number of roof ties shall be as follows: 
Single-wide homes, length $\leq 18.29 \mathrm{~m}(60 \mathrm{ft})-3$ ties.

Single-wide homes, length $\geq 18.59 \mathrm{~m}(61 \mathrm{ft})-4$ ties.

Double-wide homes - roof ties required only if installed by the manufacturer.

o Anchorage to Resist Forces in Longitudinal Direction:

No specific requirements.

o Other:

Auger anchors shall be installed to a minimum depth of $1.22 \mathrm{~m}(4 \mathrm{ft})$ in undisturbed or compacted soil.

Reference: Anchor and Tie-Down Installation Standards for Mobile/Manufactured Homes and Park Trailers, Department of Highway Safety \& Motor Vehicles, Division of Motor Vehicles, Bureau of Mobile Home \& Recreational Vehicle Construction.

\section{MINNESOTA}

o Design Loads:

Horizontal $=718 \mathrm{~Pa}(15 \mathrm{psf})$

Uplift $=431 \mathrm{~Pa}(9 \mathrm{psf})$

Snow load $=1,436 \mathrm{~Pa}(30 \mathrm{psf})$

o Pier Spacing:

Per manufacturer's instructions. For homes for which installation instructions are not available, piers shall be spaced not more than $3.05 \mathrm{~m}(10 \mathrm{ft})$ apart for mobile homes 3.66 $\mathrm{m}(12 \mathrm{ft})$ wide or less, and not more than $2.44 \mathrm{~m}(8 \mathrm{ft})$ apart for mobile homes over 3.66 $\mathrm{m}(12 \mathrm{ft})$ wide, beginning from the front wall of the mobile home, with not more than

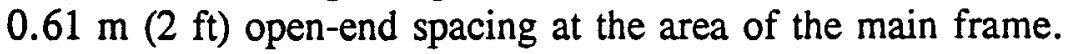

o Pier to Main-Frame Connection:

Piers shall be securely attached to the frame of the mobile home or shall extend at least $152 \mathrm{~mm}(6 \mathrm{in}$.) from the centerline of the frame member.

- Anchor and Tie Capacity:

Working load $=14.0 \mathrm{kN}(3,150 \mathrm{lbf})$

50 percent overload or $21.0 \mathrm{kN}(4,725 \mathrm{lbf})$ without failure.

o Allowable Anchor Displacements:

Vertical $=51 \mathrm{~mm}(2 \mathrm{in}$.$) with vertical tie loaded to 21.0 \mathrm{kN}(4,725 \mathrm{lbf})$

Horizontal $=102 \mathrm{~mm}(4 \mathrm{in}$.) with diagonal tie loaded to $14.0 \mathrm{kN}(3,150 \mathrm{lbf})$

o Stabilizer Plates:

Stabilizer plates are not required. 
o Anchor and Tie Spacing:

Identical with non-hurricane requirements of Table 2-5.4.9, NCSBCS A225.1-1987, Manufactured Home Installations.

o Anchorage to Resist Forces in Longitudinal Direction:

No specific requirements.

Reference: Manufactured Home Rules, Chapter 1350, Extracted from Minnesota Rules 1989 as in effect on April 3, 1989, Department of Administration.

\section{TEXAS}

- Design Loads:

Wind loads as specified in the Federal MHCSS Section 3280.305(c)(1) and (2).

o Pier Spacing:

Manufactured homes shall be supported in accordance with the home manufacturer's installation instructions or the following requirements:

Piers for single-section homes are to be placed under each longitudinal main frame member not to exceed $2.44 \mathrm{~m}(8 \mathrm{ft})$ on-center spacing for homes that are $4.27 \mathrm{~m}(14 \mathrm{ft})$ wide or less and $1.83 \mathrm{~m}(6 \mathrm{ft})$ on-center spacing for homes that are over $4.27 \mathrm{~m}(14 \mathrm{ft})$ wide. Where practical, end piers shall be placed within $0.30 \mathrm{~m}(1 \mathrm{ft})$ of the ends of the main frame.

Piers for multi-section homes are to be placed under each longitudinal main frame member not to exceed $1.83 \mathrm{~m}(6 \mathrm{ft})$ on-center spacing

o Pier to Main-Frame Connection:

No specific requirements.

o Anchor and Tie Capacity:

Working load $=14.0 \mathrm{kN}(3,150 \mathrm{lbf})$

50 percent overload or $21.0 \mathrm{kN}(4,725 \mathrm{psf})$ without failure.

o Allowable Anchor Displacements:

Anchor head movement of $76 \mathrm{~mm}(3 \mathrm{in}$.$) at 21.0 \mathrm{kN}(4,725 \mathrm{lbf})$ for single-headed anchors and $29.4 \mathrm{kN}(6,610 \mathrm{lbf})$ for double-headed anchors.

- Stabilizer Plates:

Stabilizer plates are not required. 
- Anchor or Tie Spacing:

The minimum number of ties required per side shall be sufficient to resist the wind loads stated in the Federal MHCSS Section 3280.305(c)(1) and (2).

Multi-section homes require only diagonal frame ties which shall be placed along the main frame and below the outer side wall.

Requirements for the number of vertical ties depend upon location (Hurricane or NonHurricane Zone), length of home and width of home.

- Anchorage to Resist Forces in Longitudinal Direction:

No specific requirements.

Reference: Texas Manufactured Housing Act, Civil Statutes Article 5221f, Administrative Rules, and Civil Statutes Article 9100, Department of Licensing and Regulation. 